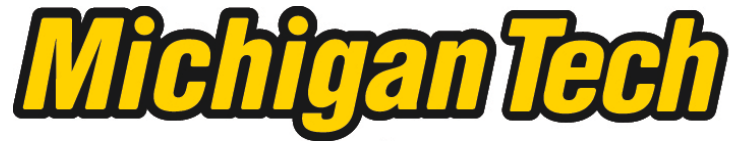 \\ Michigan Technological University Create the Future Digital Commons @ Michigan Tech
}

Dissertations, Master's Theses and Master's Reports - Open

Dissertations, Master's Theses and Master's

Reports

2013

Spatial and temporal patterns in ungulate-ecosystem interactions

Bryan D. Murray

Michigan Technological University

Follow this and additional works at: https://digitalcommons.mtu.edu/etds

Part of the Ecology and Evolutionary Biology Commons, Forest Sciences Commons, and the Natural Resources and Conservation Commons

Copyright 2013 Bryan D. Murray

\section{Recommended Citation}

Murray, Bryan D., "Spatial and temporal patterns in ungulate-ecosystem interactions", Dissertation, Michigan Technological University, 2013.

https://doi.org/10.37099/mtu.dc.etds/635

Follow this and additional works at: https://digitalcommons.mtu.edu/etds

Part of the Ecology and Evolutionary Biology Commons, Forest Sciences Commons, and the Natural Resources and Conservation Commons 


\title{
SPATIAL AND TEMPORAL PATTERNS IN UNGULATE-ECOSYSTEM
} INTERACTIONS

\author{
By \\ Bryan D. Murray

\begin{abstract}
A DISSERTATION
Submitted in partial fulfillment of the requirements for the degree of DOCTOR OF PHILOSOPHY

In Forest Science
\end{abstract} \\ MICHIGAN TECHNOLOGICAL UNIVERSITY \\ 2013 \\ (C) 2013 Bryan D. Murray
}


This dissertation has been approved in partial fulfillment of the requirements for the Degree of DOCTOR OF PHILOSOPHY in Forest Science.

School of Forest Resources and Environmental Science

Dissertation Advisor: Christopher R. Webster

Committee Member: Joseph K. Bump

Committee Member: Casey J. Huckins

Committee Member: John A. Vucetich

School Dean: Terry Sharik 


\section{Table of Contents}

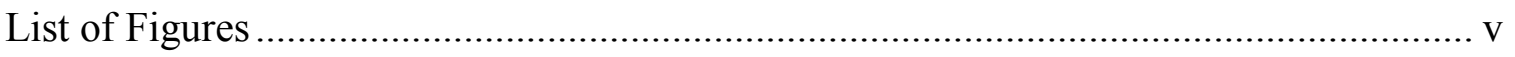

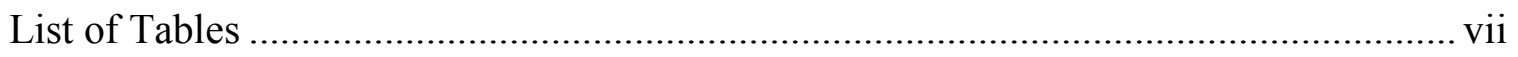

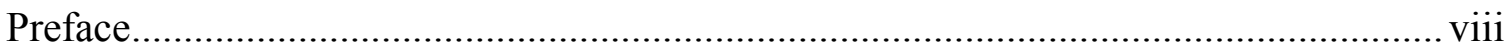

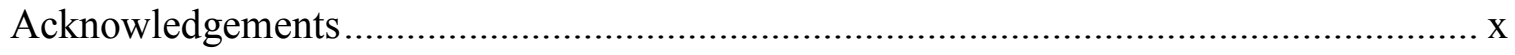

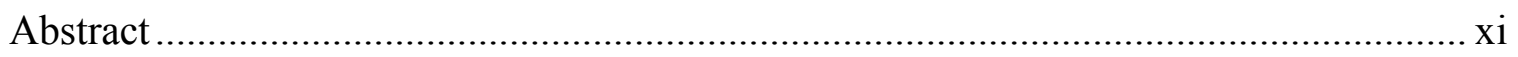

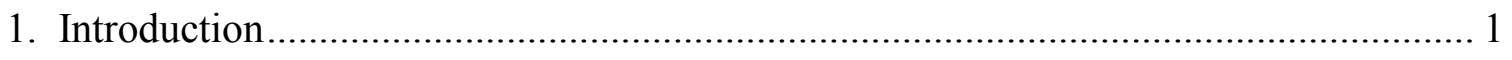

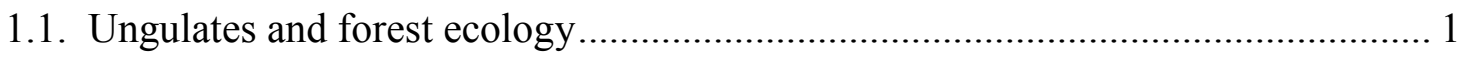

1.2. White-tailed deer and eastern hemlock in the Upper Great Lakes region .............. 2

1.3. Moose in Isle Royale National Park ......................................................... 3

2. Broadening the ecological context of ungulate-ecosystem interactions: the importance of space, seasonality, and nitrogen ............................................................. 5

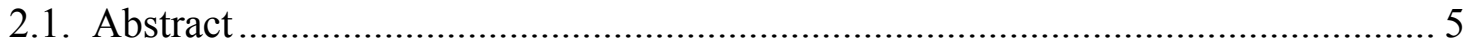

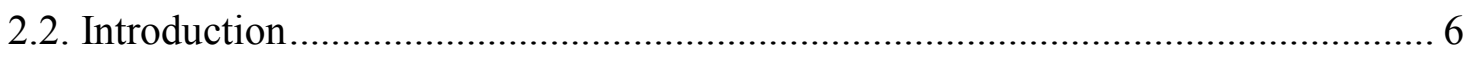

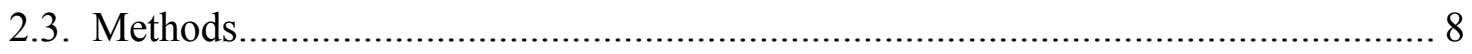

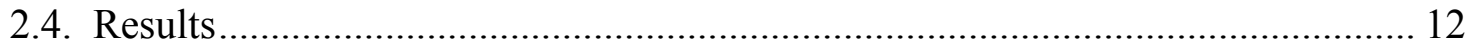

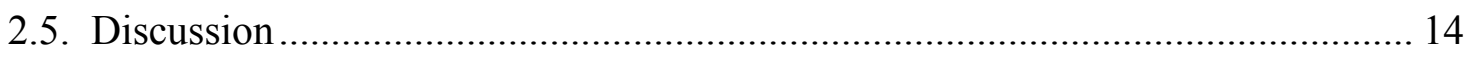

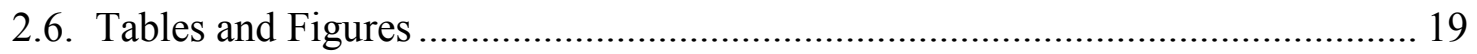

2.7. Appendix 2.A. Ottawa National Forest and Ford Forestry Center study site

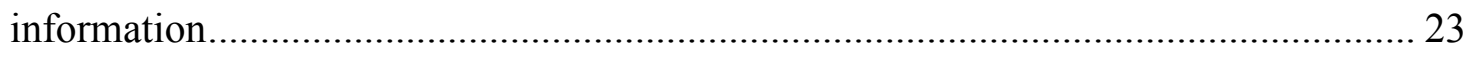

2.8. Appendix 2.B. Detailed description of deer use survey, ion-exchange resin bag, and spatial variance modeling methodologies ....................................................... 25

2.9. Appendix 2.C. Data tables describing understory tree height class distributions

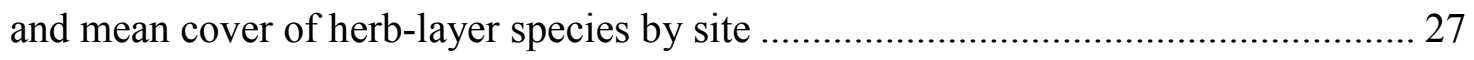

3. A migratory ungulate facilitates cross-boundary nitrogen transport in forested

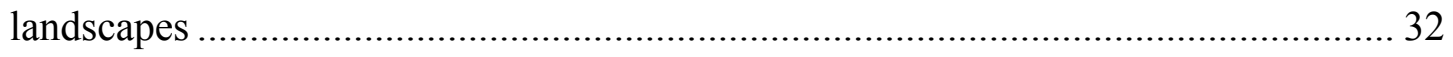

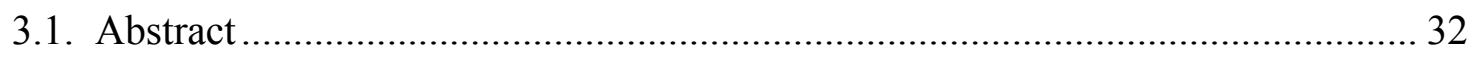

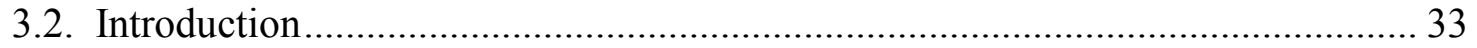

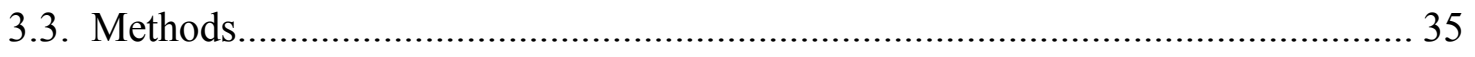

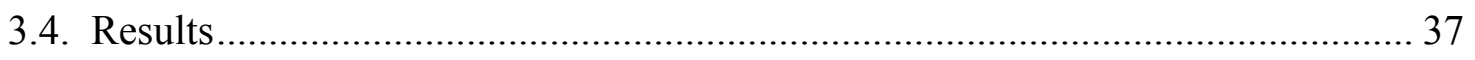




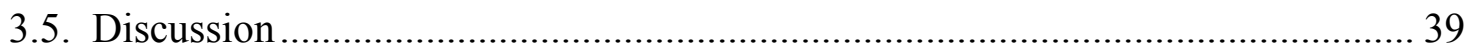

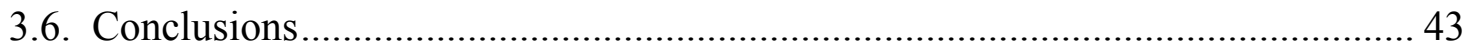

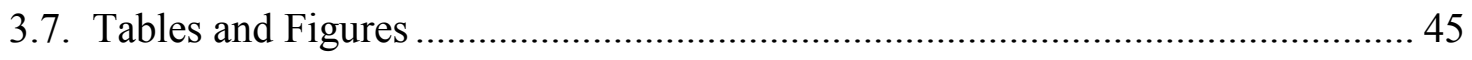

4. Interactions of forage preference and foliar chemistry: implications for forest structure

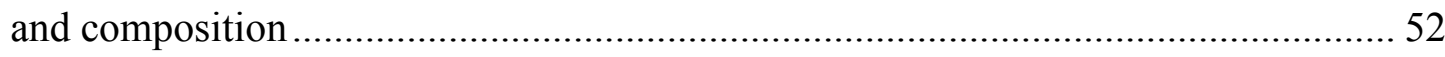

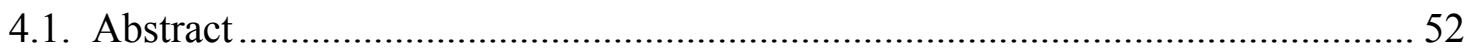

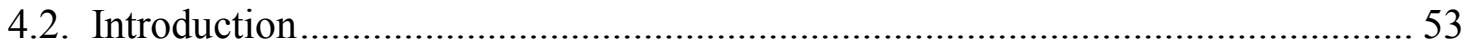

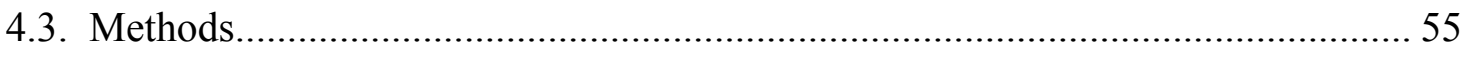

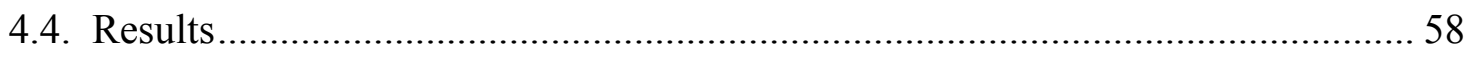

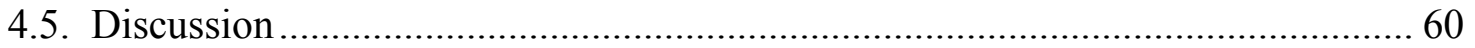

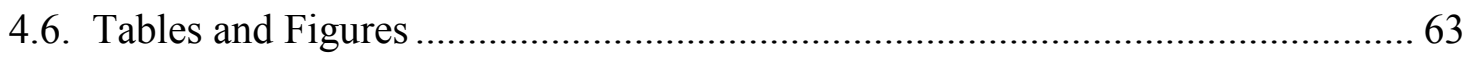

5. Post-disturbance plant community dynamics following a rare natural-origin fire in a Tsuga canadensis forest.................................................................................. 73

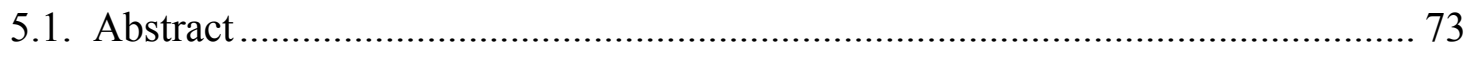

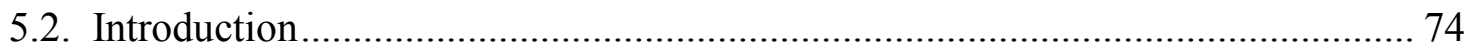

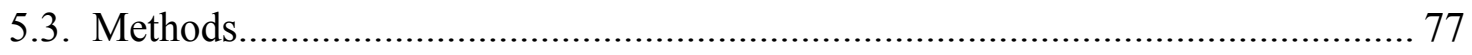

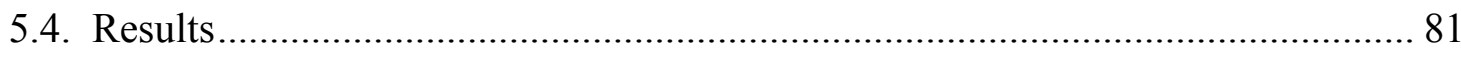

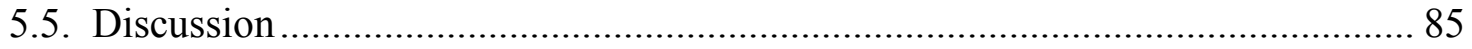

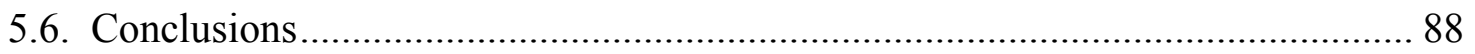

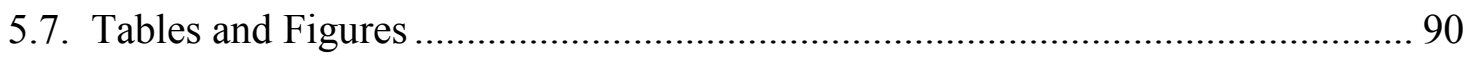

5.9. Appendix 5.A. Vegetation data for hemlock fire study ........................................ 97

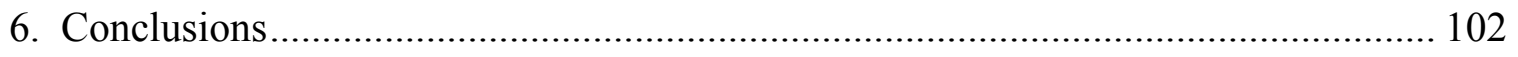

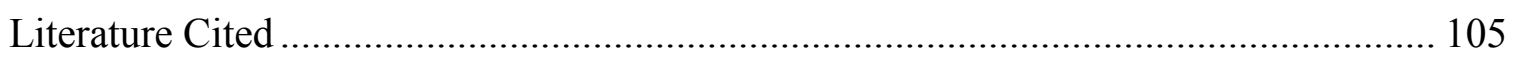




\section{List of Figures}

Figure 2.1. Stand level means of nitrogen, light, and herbaceous cover according to white-tailed deer access.

Figure 2.2. Semivariograms of nitrogen, light, and herbaceous cover according to white-tailed deer access.

Figure 2.A.1. Stand locations for spatial patterning study.

Figure 2.B.1. Sampling design for measuring spatial patterning of resources and herbaceous-layer cover in forest understories

Figure 3.1. Annual deer-excreted nitrogen inputs and mean snow depth grouped by stand

Figure 3.2. Frequency distributions of deer fecal pellet group occurrence over by plot over eight years.

Figure 3.3. Relationship between deer-excreted nitrogen inputs and the coefficient of variation in plot level deer use.

Figure 3.4. Spatial patterns in coefficient of variation in deer use and deer-excreted nitrogen inputs over eight years

Figure 4.1. Moose browse impacts on balsam fir height and allometry.....

Figure 4.2. Balsam fir sapling growth form and $\mathrm{C}: \mathrm{N}$ by soil type

Figure 4.3. Relationships between moose browse impact on balsam fir allometry and foliar chemistry

Figure 5.1. Fire and soil scarification in an eastern hemlock forest.

Figure 5.2. Effects of fire and soil scarification on the understory environment of an eastern hemlock forest.

Figure 5.3. Annual changes in seedling densities according to disturbance type. 
Figure 5.4. Annual herbaceous-layer community change by disturbance type.

Figure 5.5. Annual summer Palmer Drought Severity Index in northern Wisconsin,

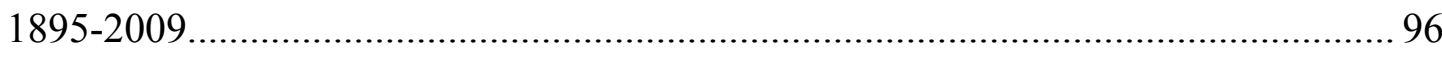




\section{List of Tables}

Table 2.1. Comparison of stand level means by Monte Carlo randomization tests..........19

Table 2.2. Parameter estimates for the most parsimonious semivariogram models.........20

Table 2.A.1. Description of study stands in terms of land area, relative deer use,

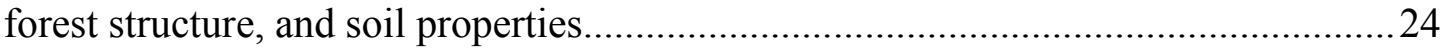

Table 2.C.1. Woody stem density by height class and deer access............................. 27

Table 2.C.2. Mean percent cover of herbaceous-layer vegetation by species and stand.

Table 3.1. Summary statistics describing site-level N excretion by white-tailed deer in winter habitat patches of eastern hemlock........................................................ 45

Table 3.2. Models of deer fecal pellet counts and snow pack duration and depth parameters in persistent deeryards

Table 4.1. The structure and composition of boreal forest study sites in Isle Royale National Park, Michigan, USA

Table 4.2. Results of one-tailed $t$-tests comparing measures of balsam fir foliar chemistry among deep and glacially scoured soil types

Table 4.3. Model selection for drivers of balsam fir foliar chemistry 65

Table 4.4. Parameter estimates for the most parsimonious model of C:N

Table 4.5. Parameter estimates for the most parsimonious model of $\Delta$

Table 5.1. Significant indicator species by disturbance type after one, two, and three years since disturbance.

Table 5.A.1. Mean percent cover of herbaceous-layer vegetation by disturbance type after one, two, and three years since disturbance. 


\section{Preface}

Chapters within this work include the text and figures of multi-authored, peer-reviewed journal articles in various stages of preparation, submission, review, and publication. Copyright (if necessary), authorship, and current status for each chapter are provided below. Previously published chapters are acknowledged as a footnote citation on the first page of the chapter.

Chapter 2, Broadening the ecological context of ungulate-ecosystem interactions: the importance of space, seasonality, and nitrogen: (C) by the Ecological Society of America 2013. Special permission to republish an article in the author's dissertation is not required (http://esapubs.org/esapubs/permissions.htm). Study design, field and laboratory work, data analysis, figures and tables, and majority of writing performed by Bryan Murray. Study design, some writing and editing, and direction contributed by Christopher Webster and Joseph Bump.

Chapter 3, A migratory ungulate facilitates cross-boundary nitrogen transport in forested landscapes: in preparation for submission to the peer-reviewed journal Oikos. Field work, data analysis, creation of figures and tables, and majority of writing performed by Bryan Murray. Study design, some writing and editing, and direction contributed by Christopher Webster. Some ideas, writing, and editing provided by Joseph Bump.

Chapter 4, Interactions of forage preference and foliar chemistry: implications for forest structure and composition: in preparation for submission to the peer-reviewed journal Oecologia. Study design, field and laboratory work, data analysis, creation of figures and tables, and majority of writing performed by Bryan Murray. Study design, some writing and editing, and direction contributed by Christopher Webster, John Vucetich, and Joseph Bump. Some ideas and direction provided by Erik Lilleskov.

Chapter 5, Post-disturbance plant community dynamics following a rare natural-origin fire in a Tsuga canadensis forest: (C) Murray et al. 2012. This work is licensed under the 
Creative Commons Attribution 2.5 Generic License, which permits unrestricted use, distribution, and reproduction in any medium, provided the original author and source are credited. To view a copy of this license, visit http://creativecommons.org/licenses/by/2.5/ or send a letter to Creative Commons, 444 Castro Street, Suite 900, Mountain View, California, 94041, USA. Data analysis, creation of figures and tables, and the majority of writing performed by Bryan Murray. Study design, field work, and editing performed by Stacie Holmes and Jill Witt. Study design, assistance with data analysis, Figure 5.1, some writing and editing, and direction provided by Christopher Webster. 


\section{Acknowledgements}

Numerous people contributed to making this dissertation a success. First, I would like to thank Chris Webster, my advisor, for guiding, challenging, and encouraging me along the way. I am grateful to my committee members Joseph Bump, John Vucetich, and Casey Huckins for their valuable feedback and thoughtful advice. I also thank Andrew Burton, Jennifer Eikenberry, Mike Hyslop, Marty Jurgensen, Evan Kane, Erik Lilleskov, Sigrid Resh, Dana Richter, Catherine Tarasoff, Ken Vrana, and Leah Vucetich for helping at one or many stages of this project.

The field and laboratory work, often tedious and/or strenuous, would not have been possible without the assistance of several undergraduate and graduate student technicians. I thank Aaron Wuori for his hard work and dedication on Isle Royale, the pellet counts, and the exclosure study. Betsy Tahtinen collaborated with me at all stages of the exclosure study. Eric Dipping assisted with the pellet counts for four consecutive field seasons, processed fisheye photos, and separated lichens from balsam fir foliage. Stephen Fick assisted with the pellet counts and exclosure study. Krista Fischler helped process balsam fir samples and construct resin bags. I also thank the following technicians for their help counting deer pellets: Nia Becker, Kristin Brusso, Winona Genther, Sara Nevalainen, Travis Pond, and Andrea Wodzinski.

Funding for this work was provided by the McIntire-Stennis Cooperative Forestry Program, the Ecosystem Science Center, and the Michigan Department of Natural Resources Wildlife Division. The Ottawa National Forest, Chequamegon-Nicolet National Forest, Isle Royale National Park, Michigan Department of Natural Resources, and Gratiot Lake Conservancy allowed us to work their lands. The National Park Service, Isle Royale Institute, and Isle Royale Wolf-Moose Study provided logistical support. Helpful study site information was provided by Susanne Adams, Brian Bogaczyk, Lisa Brehm, Robert Doepker, Robert Evans, Mary Lucas, Andy Meyers, Linda Parker, Mark Romanski, Gayle Sironen, and Dave Steffensen.

Lastly, I thank my family and friends for their encouragement and support. My wife, Sarah Murray, assisted in many ways, including the editing of a previous draft of this dissertation. 


\section{Abstract}

Ungulates are important components of a variety of ecosystems worldwide. This dissertation integrates aspects of ungulate and forest ecology to increase our understanding of how they work together in ways that are of interest to natural resource managers, educators, and those who are simply curious about nature. Although animal ecology and ecosystem ecology are often studied separately, one of the general goals of this dissertation is to examine how they interact across spatial and temporal scales. Forest ecosystems are heterogeneous across a range of scales. Spatial and temporal habitat use patterns of forest ungulates tend to be congregated in patches where food and/or cover are readily available. Ungulates interact with ecosystem processes by selectively foraging on plants and excreting waste products in concentrated patches. Positive feedbacks may develop where these activities increase the value of habitat through soil fertilization or the alteration of plant chemistry and architecture. Heterogeneity in ecosystem processes and plant community structure, observed at both stand and local scales, may be the integrated outcome of feedbacks between ungulate behavior and abiotic resource gradients.

The first chapter of this dissertation briefly discusses pertinent background information on ungulate ecology, with a focus on white-tailed deer (Odocoileus virginianus) in the Upper Great Lakes region and moose (Alces acles) in Isle Royale National Park, Michigan, USA. The second chapter demonstrates why ecological context is important for studying ungulate ecology in forest ecosystems. Excluding deer from eastern hemlock (Tsuga canadensis) stands, which deer use primarily as winter cover, resulted in less spatial complexity in soil reactive nitrogen and greater complexity in diffuse light compared to unfenced stands. The spatial patterning of herbaceous-layer cover was more similar to nitrogen where deer were present, and was a combination of nitrogen and light within deer exclosures. This relationship depends on the seasonal timing of deer habitat use because deer fertilize the soil during winter, but leave during the growing season. The third chapter draws upon an eight-year, 39-stand data set of deer fecal pellet counts in hemlock stands to estimate the amount of nitrogen that deer are depositing in hemlock stands each winter. In stands of high winter deer use, deer- 
excreted nitrogen inputs consistently exceeded those of atmospheric deposition at the stand scale. At the neighborhood scale, deer-excreted nitrogen was often in excess of atmospheric deposition due to the patchy distribution of deer habitat use. Spatial patterns in habitat use were consistent over the eight-year study at both stand and neighborhood scales. The fourth chapter explores how foraging selectivity by moose interacts with an abiotic resource gradient to influence forest structure and composition. Soil depth on Isle Royale varies from east to west according to glacial history. Fir saplings growing in deeper soils on the west side are generally more palatable forage for moose (lower foliar $\mathrm{C}: \mathrm{N})$ than those growing in shallower soils on the east side. Therefore, saplings growing in better conditions are less likely to reach the canopy due to moose browsing, and fir is a smaller overstory component on the west side. Lastly, chapter five focuses on issues surrounding eastern hemlock regeneration failure, which is a habitat type that is important to many wildlife species. Increasing hemlock on the landscape is complicated by several factors including disturbance regime and climate change, in addition to the influence of deer. 


\section{Introduction}

\subsection{Ungulates and forest ecology}

The redistribution of nitrogen by animals, particularly large ungulate herbivores in terrestrial ecosystems, is an important mechanism that tends to increase resource heterogeneity (Steinauer and Collins 1995, Augustine and Frank 2001). Ungulate herbivores affect spatial patterning in nitrogen availability through direct and indirect mechanisms. Direct effects occur by the excretion of nitrogenous wastes in concentrated patches, referred to as biogeochemical hotspots (Afzal and Adams 1992, Steinauer and Collins 1995, Augustine and Frank 2001, Peek and Forseth 2003) and the decomposition of carcasses (Towne 2000; Bump et al. 2009b). Indirect effects occur due to preferential browsing of more nutritious plant species, resulting in a plant community shift towards less nutritious species that produce less nutritious leaf litter for decomposers. As a result, nitrogen availability to soil biota and associated processes declines (Pastor et al. 1993, Bardgett and Wardle 2003, Bressette et al. 2012).

The current literature suggests that ungulates accelerate nitrogen cycling in grassland ecosystems via direct mechanisms, whereas decelerating indirect mechanisms are predominant in forest ecosystems (Pastor et al. 2006). This pattern has been observed in tundra (Olofsson et al. 2004), boreal forest (Pastor et al. 1993), temperate grassland (Augustine et al. 2003, Singer and Schoenecker 2003) and forest (Ritchie et al. 1998, Bressette et al. 2012), and tropical grassland (McNaughton 1985) and forest (Feeley and Terborgh 2005) ecosystems. The explanation for the pattern is that grassland ungulate diets are higher in nitrogen content compared to diets of forest ungulates, and grassland ungulates congregate in much larger groups than forest ungulates (Pastor et al. 2006). Also, most grasses possess traits to survive and rapidly replace lost tissue after grazing (Coughenour 1985). 


\subsection{White-tailed deer and eastern hemlock in the Upper Great Lakes region}

White-tailed deer (Odocoileus virginianus) populations have increased dramatically in eastern North America over the last century (Ripple et al. 2010). In Michigan's Upper Peninsula, Deer density doubled from presettlement times to the 1990s (Doepker et al. 1995). The direct effects of deer browsing on tree regeneration (Alverson et al. 1988, Rooney et al. 2000, Rooney et al. 2002), and understory herbaceous plant diversity in forest ecosystems (Rooney and Dress 1997, Côté et al. 2004, Rooney 2009) have been well documented (Russell et al. 2001, Rooney and Waller 2003).

Eastern hemlock (Tsuga canadensis) is an important component in the northern hardwoods forest mosaic of the northern Great Lakes region. Hemlock acts as a foundation species by forming monotypic stands with distinct temperature, moisture, light, and nutrient conditions (Ellison et al. 2005). While hemlock was more common before European settlement, its range has been greatly reduced by the forest management practices of the late $19^{\text {th }}$ and early $20^{\text {th }}$ centuries (Frelich 1995). It is currently threatened by hemlock woolly adelgid (Jenkins et al. 1999), climate change, and browsing by deer (Frelich and Lorimer 1985, Mladenoff and Stearns 1993, Rooney et al. 2000, Witt and Webster 2010). Hemlock stands also provide critical winter habitat for deer during severe winters (Rongstand and Tester 1969, Van Deelen et al. 1998).

The presence of dense overwintering deer populations in hemlock stands presents an excellent opportunity to examine the impacts of deer on nutrient cycling, tree regeneration, and understory vegetation in forest ecosystems. Seagle (2003) postulated that in agricultural regions, deer should transport nutrients from crop fields where they feed to small woodlots where they rest. A similar pattern of daily migrations was reported for deer overwintering in a northern white-cedar (Thuja occidentalis) swamp (Rongstad and Tester 1969). Seagle (2003) also hypothesized that nutrient additions to woodlots would alter plant community dynamics.

The impact of deer on nitrogen availability in northern hardwood forests is important to hemlock conservation and the understory vegetation communities in hemlock stands. Deer may impact hemlock regeneration directly through browsing 
(Frelich and Lorimer 1985, Rooney et al. 2000), or indirectly by increasing nitrogen availability through urinary and fecal deposition (Augustine and Frank 2001, Seagle 2003). Hemlock forest soils are typically low in nitrogen because hemlock litter is recalcitrant, making it difficult for hardwoods like sugar maple to establish in the understory. Excess nitrogen is hypothesized to benefit sugar maple more than hemlock because hemlock responds more slowly to increased nitrogen than sugar maple (Tripler et al. 2002). Therefore, increased nitrogen deposition from denser deer populations may be indirectly impacting hemlock regeneration by increasing the competitive ability of hardwoods such as sugar maple. Sugar maple regeneration has been observed in hemlock stands throughout western upper Michigan (Witt and Webster 2010).

If deer increases inorganic nitrogen availability through urinary and fecal deposition, nitrogen additions should be concentrated in biogeochemical hotspots. Elk (Cervus elaphus) generate hotspots of grass productivity at small scales in Yellowstone National Park (Augustine and Frank 2001). Mule deer (Odocoileus hemionus) generate hotspots of nitrogen availability, growth, and productivity of the herbaceous perennial Cryptantha flava in areas where they urinate (Peek and Forseth 2003). Furthermore, deer do not use all areas of their winter habitats equally, but tend to select microhabitats based on overstory cover and browse availability (Morrison et al. 2003).

\subsection{Moose in Isle Royale National Park}

Isle Royale National Park, Michigan, USA, is a $544 \mathrm{~km}^{2}$ archipelago in Lake Superior that is approximately $25 \mathrm{~km}$ from mainland Ontario (Snyder and Janke 1976). The archipelago runs lengthwise in a northeast-southwest orientation, and is approximately $72 \mathrm{~km}$ long and up to $14 \mathrm{~km}$ wide, and composed of one main island and about 200 outer islands (Snyder and Janke 1976). The distribution of forest types is influenced by proximity to Lake Superior and elevation. East side forests are dominated by boreal forest trees such as balsam fir, white spruce (Picea glauca), black spruce (Picea mariana), quaking aspen (Populus tremuloides), and paper birch (Betula papyrifera). West side boreal forest habitats are located along the lakeshore, while inland forests are composed of species more indicative of northern hardwood forests, such as sugar maple 
(Acer saccharum), northern red oak (Quercus rubra), and yellow birch (Betula alleghaniensis). The structure and composition of Isle Royale's boreal forests varies considerably from the east to the west ends of the island, with greater basal area and canopy cover at higher elevations in the west.

Moose arrived on Isle Royale around 1910. Since then, the population abundance has fluctuated greatly. The highest population size was likely reached circa 1930 (Snyder and Janke 1976). Since 1958 moose population abundance has been estimated annually using a combination of cohort analysis and aerial surveys (Vucetich and Peterson 2004). During that time it has experienced two time periods of relative high abundance, the 1970s and mid-1990s (Vucetich and Peterson 2004). Moose are semi-aquatic during the summer months, and move to upland sites of boreal type forests during winter, where they sustain themselves by browsing woody vegetation and utilizing fat and protein reserves. Belovsky (1981) reported that balsam fir (Abies balsamea) and northern whitecedar (Thuja occidentalis) were among the most preferred winter browse species. Since moose arrived on the island, the abundance of balsam fir has greatly declined, and Canada yew (Taxus canadensis), a highly preferred shrub that rarely grows above the reach of moose, has been eliminated except for certain island and boulder-top refugia (Snyder and Janke 1976). 


\section{Broadening the ecological context of ungulate- ecosystem interactions: the importance of space, seasonality, and nitrogen ${ }^{1}$}

\subsection{Abstract}

Spatial heterogeneity of soil resources, particularly nitrogen availability, affects herbaceous-layer cover and diversity in temperate forest ecosystems. Current hypotheses predict that ungulate herbivores influence nitrogen availability at the stand scale, but how ungulates affect nitrogen availability at finer spatial scales that are relevant to the herblayer is less understood. We tested the hypothesis that ungulate exclusion reduces the spatial complexity of nitrogen availability at neighborhood scales (1-26m) apart from mean stand scale effects. This outcome was expected due to a lack of ungulate nitrogenous waste deposition within exclosures and seasonally variable ungulate habitat use. To test this hypothesis we examined spatial patterning of ammonium and nitrate availability, herb-layer cover and diversity, and under-canopy solar radiation using geostatistical models. Our study sites included six stands of eastern hemlock (Tsuga canadensis) forest: three where white-tailed deer (Odocoileus virginianus) were excluded and three that were accessible to deer. Where deer were present patch sizes of ammonium availability, cover, and diversity were smaller compared to deer exclosures whereas mean site level effects were not significant. Within deer exclosures cover and solar radiation were more similar in patch size than were cover and nitrogen availability. Our results suggest that browsing ungulates affect spatial patterns of herb-layer cover and diversity through the excretion of nitrogenous wastes in small, discrete patches. Ungulate-excreted nitrogen deposition and herbivory were concentrated in the dormant season, allowing herb-layer plants a greater opportunity to benefit from nitrogen additions. Therefore, the impact of ungulates on nitrogen cycling in forest ecosystems varies with spatial scale and

\footnotetext{
${ }^{1}$ This chapter (C) by the Ecological Society of America 2013. Citation: Murray, B. D., C. R. Webster, and J. K. Bump. 2013. Broadening the ecological context of ungulate-ecosystem interactions: the importance of space, seasonality, and nitrogen. Ecology 94:1317-1326.
} 
the seasonal timing of ungulate impacts. In this way, ungulates may function as a seasonally-dependent link between fine scale and landscape level ecological processes.

\subsection{Introduction}

Determining what controls spatial and temporal patterns of nitrogen availability has important implications for understanding and maintaining key ecosystem functions (Gilliam 2006). Nitrogen is a limiting resource to primary production in many terrestrial ecosystems (Vitousek and Howarth 1991), and processes that influence spatial patterns in nitrogen availability influence plant biomass, competitive relationships, and thereby biodiversity (Vitousek et al. 1997, Gilliam 2006). Nitrogen availability is often homogenized by current human activities, especially via atmospheric deposition, which emphasizes the need to understand the mechanisms and context dependence (sensu Schmitz 2010) of processes that affect nitrogen heterogeneity. Such an understanding is important to address the homogenizing effects of human activities and develop a predictive understanding of ecosystem function.

The seasonal redistribution of nitrogen by animals such as ungulate herbivores is an important mechanism that tends to increase the spatial heterogeneity of nitrogen in terrestrial ecosystems (Steinauer and Collins 1995, Augustine and Frank 2001). Ungulate herbivores affect nitrogen availability through direct and indirect mechanisms. Direct effects occur by ungulates ingesting nitrogen from across the landscape and concentrating it into hotspots of excreta (Steinauer and Collins 1995, Augustine and Frank 2001, Peek and Forseth 2003) and carcasses (Bump et al. 2009b). Seasonal or diurnal habitat use patterns can facilitate a net transport of nitrogen across habitat boundaries (Seagle 2003, Abbas et al. 2012). Indirect effects occur due to preferential browsing of more palatable plant species, resulting in a plant community transition toward less nutritious species that produce lower quality leaf litter for decomposers. As a result, nitrogen availability to soil biota and associated processes declines (Pastor et al. 1993, Bardgett and Wardle 2003, Bressette et al. 2012).

Although available evidence indicates that ungulates generally decelerate nitrogen cycling rates in forest ecosystems via indirect effects (Ritchie et al. 1998, reviewed in 
Pastor et al. 2006), few studies have addressed the importance of spatial heterogeneity at fine spatial scales of 1-20 m, which are influential in herbaceous-layer community dynamics (Frelich 2002, Gilliam 2007). In grasslands, ungulate excreta can increase heterogeneity of nitrogen availability at such fine scales (Steinauer and Collins 1995, Augustine and Frank 2001, Peek and Forseth 2003). Ungulate carcasses can generate nutrient hotspots for vegetation growth in grasslands (Towne 2000) and forest understories (Bump et al. 2009b). Modeling of ungulate habitat use patterns and nitrogen excretion rates suggests that impacts are expected to be heterogeneous at the landscape scale (Seagle 2003, Abbas et al. 2012). Ungulate effects on landscape- and local-scale nitrogen availability may link coarse- and fine-scale processes, as does ungulate herbivory (Hurley et al. 2012).

We tested the hypothesis that stands with ungulate access would have more complex fine scale spatial patterns of nitrogen availability and detectable nitrogen hotspots compared to exclosures, but exhibit no difference in mean nitrogen availability at the stand scale. If true, we also expected herb-layer cover and diversity to exhibit differences in spatial patterns at fine scales, but not necessarily mean differences at the stand scale. We expected greater complexity in spatial patterns of nitrogen availability due to deposition of ungulate excreta in discrete patches (Steinauer and Collins 1995, Augustine and Frank 2001). Increased nitrogen availability would increase plant growth rates (Peek and Forseth 2003) given that primary production in temperate forests is often nitrogen-limited (Vitousek and Howarth 1991) and temperate forest plants often possess adaptations to rapidly capitalize on ephemeral nitrogen pulses (Farley and Fitter 1999). We did not expect considerable consumptive effects because the seasonal timing of nitrogen inputs and herbivory are decoupled in our study system (Jensen et al. 2011, Witt et al. 2012). Ungulate use, and therefore nitrogen deposition and herbivory, occur mainly during the dormant season, allowing herbaceous plants increased nitrogen availability and reduced herbivory risk during the growing season. We tested this hypothesis using 3 large ungulate exclosures (up to $30 \mathrm{ha}$ ) and 3 nearby unexclosed sites located in winter ungulate habitat. Our within-site sampling design captured spatial variance at a scale of 1-26 m, which is relevant to herb-layer community interactions (Frelich 2002, Gilliam 2007). These analyses address the fundamental questions: at what spatial scales do 
ungulates affect nitrogen availability and what are the implications for herbaceous-layer vegetation?

\subsection{Methods}

\subsubsection{Study sites}

Our study occurred in six eastern hemlock (Tsuga canadensis)-dominated stands in the western Upper Peninsula of Michigan (Appendix 2.A, Fig. 2.A.1). Three stands (Boneyard, Spree, and Walton Creek) were entirely enclosed by a $2 \mathrm{~m}$ tall fence that excluded white-tailed deer (Odocoileus virginianus) while allowing access to smaller animals. Three other stands (Ford Forestry Center, Silver River, and Sylvania) were accessible to deer. Deer exclosures were constructed in 2003 (Walton Creek) and 2007 (Boneyard and Spree). Deer access sites were selected from a set of 39 remnant hemlock stands in the western Upper Peninsula where winter deer use has been monitored since 2006 (see Appendix 2.B.1 and Witt and Webster 2010 for details). The deer access site selection criteria in the current study included high deer use during 2006-2010, intermediate size (10-30 ha), and similar soil type and forest structure to the previouslyconstructed exclosures (see Appendix 2.A, Table 2.A.1 for site information). Prior to the study year of 2011, the selected access sites experienced winter deer use well above the 39-site average. Growing season deer use was considerably less than winter deer use, and growing season deer herbivory was also less than expected based on winter deer use (Witt et al. 2010, Jensen et al. 2011). The deer exclosures used in our study, at 4 ha and 30 ha area, were unusually large for temperate forest regions.

\subsubsection{Sampling design}

A cyclical sampling network was used to efficiently measure spatial patterning across a range of scales from single tree (1-10m) to neighborhood $(10-20 \mathrm{~m}$; Frelich 2002). At each site, 1 x $1 \mathrm{~m}$ quadrants were placed in a repeating cycle of $0,1,3$, and $9 \mathrm{~m}$ every $13 \mathrm{~m}$ along two intersecting $52 \mathrm{~m}$ transects. Transects intersected at the midpoint at a $60^{\circ}$ angle (see Appendix 2.B, Fig. 2.B.1 for a diagram). This sampling design 
maximized spatial information gained from as few sample points as possible (Clinger and Van Ness 1976, Scheller and Mladenoff 2002). Sample size was 33 quadrants at each site, or 99 quadrants per treatment, for a grand total of 198 quadrants.

\subsubsection{Field data collection}

Herb-layer vegetation was sampled by a visual survey of cover by species in each quadrant. We chose cover as a surrogate for biomass to reduce our impact on the forest, and because it is a reliable indicator of biomass (Hermy 1988). The same observer conducted all surveys to maintain consistency. Herb-layer vegetation was defined as all plants $<1.0 \mathrm{~m}$ in height. Individual plants were grouped by species, with the exception of the Division Bryophyta, into the following cover classes: 0, 1, 5, 10, 25, 50, 75, 90, 95, and 99\% (McCune and Grace 2002). Early summer herb-layer species were sampled on 6-11 June 2011, whereas late summer species were sampled on 25, 27, or 29 July. A nonmetric multidimensional scaling ordination procedure conducted in PC-ORD 5 (McCune and Mefford 2006) did not reveal a stable structure for herb-layer cover data (final stress $=37.7$; instability $=0.046 ; 500$ iterations).

The abundance of woody vegetation was measured in three size classes: seedlings $(<0.25 \mathrm{~m}$ height $)$, saplings $(0.25-3.00 \mathrm{~m}$ height, $<10.0 \mathrm{~cm}$ diameter at breast height $(\mathrm{DBH}=1.37 \mathrm{~m})$ ), and trees $(\geq 10.0 \mathrm{~cm} \mathrm{DBH})$. The number of seedlings was counted by species in each quadrant. Saplings were counted by species and height was recorded.

Trees were quantified by 5 variable-radius plots (basal area factor $=2.3 \mathrm{~m}^{2} \mathrm{ha}^{-1}$ ) at each site. The center of a variable-radius plot was located at each transect terminus as well as the intersection of transects. Our sampling area for saplings and overstory trees was small and intended for descriptive purposes only.

Nitrogen ion availability was assessed by burying ion-exchange resin beads in situ, extracting the adsorbed ions in the laboratory, and colorimetrically measuring ammonium and nitrate concentrations of the extracts (described in Appendix 2.B.2). Four resin bags were buried at 5-10 cm depth in each quadrant for 91 days (7-12 March through 6-11 June 2011). We chose this time period to capture nitrogen availability from spring snowmelt through establishment of the early summer understory flora. 
The availability of light to herb-layer vegetation was estimated from digital hemispherical photographs of the canopy. Hemispherical photographs were taken from $1 \mathrm{~m}$ height during the 6-11 June sampling period. Direct and diffuse under-canopy radiation (mean photosynthetically active flux density, $\mathrm{mol} \mathrm{m}^{-2}$ day $^{-1}$ ) was computed using the computer software WinSCANOPY (WinSCANOPY 2005) and a growing season length of 1 May through 30 September.

The location of deer excreta along transects was measured by visually searching for fecal pellet groups. A pellet group was counted if it was located within $1.5 \mathrm{~m}$ of the transect center, so that $321 \mathrm{~m}^{2}$ was searched for pellet groups at each deer access site. Quadrants were visually inspected for earthworm middens, but none were observed.

\subsubsection{Site-level comparisons}

Site-level means of variables were computed as the mean of quadrant-level observations. We determined total percent cover as the sum of cover class midpoints of all species present in a quadrant. Seedling density was computed as the total number of seedlings $\mathrm{m}^{-2}$. Sapling density was computed in the same manner. We determined species richness $(S)$, Shannon's diversity index $\left(H^{\prime}\right)$ and evenness $(E)$ for each quadrant.

We compared site-level means in nitrogen availability, under-canopy radiation, and vegetation attributes between deer access and exclosure sites. Monte Carlo randomization tests on absolute mean differences (Gotelli and Ellison 2004) were used because most variables did not approximate a normal distribution. The null distribution was generated with 1000 permutations. Site-level means were considered to be statistically significantly different if $p<0.05$. Monte Carlo randomization tests were also performed on the $90^{\text {th }}$ percentiles of ammonium, nitrate, and total nitrogen ion (sum of ammonium and nitrate by quadrant) to test the hypothesis of greater nitrogen hotspots in deer access sites. We chose the $90^{\text {th }}$ percentile to test this hypothesis because it is more sensitive than the mean to extreme values. 


\subsubsection{Spatial analyses}

Spatial patterning in nitrogen availability, under-canopy radiation, herb-layer cover, and diversity were compared using semivariance analysis (Goovaerts 1998). Semivariance $(\gamma(h))$ measures the spatial variance between sample points at variable separation distances $(h)$. Semivariance was standardized by dividing by the sample variance $s^{2}$ so that all semivariograms would be on the same scale for direct comparison. Also, a standardized semivariance less than 1 (semivariance $<$ sample variance) indicates spatial dependence between sample points at a given separation distance. Standardized semivariance was computed for each $h$ up to half the transect length (1-26m) using the $\mathrm{R}$ statistical environment (R 2012) and the packages RGDAL (Keitt et al. 2012) and GSTAT (Pebesma 2004). We used the package GGPLOT2 (Wickham 2009) to generate empirical semivariograms by plotting observed $\gamma(h)$ by $h$. All variables except diversity required a Box-Cox transformation ( $n=198$ observations) to achieve normality prior to semivariance analysis.

We modeled spatial patterning in each variable by fitting 5 candidate models to each empirical semivariogram and selecting the most parsimonious model through an information-theoretic approach. We chose 5 models that are often useful for describing spatial patterning of variance: white noise (no systematic change in variance with increasing separation distance), linear (algebraic change in variance), spherical, exponential, and Gaussian (rapid change in variance at small separation distances that decreases at larger distances). The white noise model is a single-parameter model that represents random variation in variance with increasing $h$. The linear model contains slope $(m)$ and $y$-intercept $\left(\gamma_{0}\right)$ parameters and indicates a linear change in spatial dependence. The spherical, exponential, and Gaussian models each contain three parameters which represent the range of spatial dependence $(a)$, the partial sill $(C)$ which represents spatial variance explained by the model, and the nugget $(\varepsilon)$ which represents spatial variance at distances shorter than the step size as well as sampling error. For the spherical model the partial sill $C$ is the limit of $\gamma(h)$ as $h \rightarrow a$. The exponential and Gaussian models also reach $C$ asymptotically, but the practical range $a$ must be estimated from the range parameter $b$. The practical range is reached when $\gamma(h)=0.95(C)$, which 
can be computed by $a=3 b$ for the exponential model and $a=\sqrt{ } 3 b$ for the Gaussian model (Goovaerts 1998). Models were fit by the Gauss-Newton nonlinear minimization algorithm in the R statistical environment (R 2012). The weights $N_{j} / h_{j}^{2}$ were used in the sum of squares function.

From the set of 5 candidate models, we selected the most parsimonious using Akaike's Information Criterion corrected for small sample sizes $\left(\mathrm{AIC}_{\mathrm{c}}\right)$ (Burnham and Anderson 2004), computed in the R statistical environment ( $R$ 2012). We defined the most parsimonious model as having the lowest $\mathrm{AIC}_{\mathrm{c}}$ and where the $\triangle \mathrm{AIC}_{\mathrm{c}}$ of the next model $>2$ (Burnham and Anderson 2002). The most parsimonious model was used to compute the appropriate geostatistical parameters for each variable.

\subsection{Results}

\subsubsection{Deer use}

Stand level deer use during the winter of 2010-11 did not show a consistent trend across sites relative to the previous five winters (Appendix 2.A, Table 2.A.1). Pellet group density at Silver River (610.0 groups $\left.\mathrm{ha}^{-1}\right)$ was similar to previous winters $(545.5 \pm$ 99.8 groups $\left.\mathrm{ha}^{-1} ; n=5\right)$. Pellet group density was greater than any of the previous 5 years at Sylvania (1130.2 groups ha ${ }^{-1}$ vs. $366.0 \pm 105.5$ groups ha $^{-1}$ ), and lower than the previous 5 years at Ford Forestry Center (107.6 groups ha ${ }^{-1}$ vs. $355.2 \pm 62.8$ groups ha $^{-1}$ ). We estimated the proportion of each stand that was directly affected by deer excreta using the observed stand level pellet count densities. We made the conservative assumptions that 1 excretion event affects a $0.25 \mathrm{~m}^{2}$ area (Steinauer and Collins 1995) and that deer urinate and defecate simultaneously (Wallmo 1981). Deer excretion affected $1.5 \%$ of the sampled area at Silver River, $2.8 \%$ of the Sylvania site, and $0.3 \%$ of the Ford Forestry Center site. Transect fecal pellet group counts followed the same

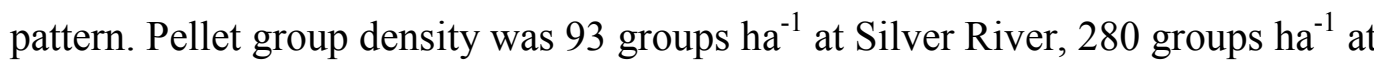
Sylvania, and no pellet groups were observed at the Ford Forestry Center. 


\subsubsection{Site level comparisons}

Ammonium, nitrate, and total nitrogen ion availability did not differ according to deer access at the site level based on Monte Carlo randomization tests of the mean (Table 2.1, Fig. 2.1). Direct and total under-canopy radiation did not differ, while diffuse undercanopy radiation was significantly greater at exclosure sites (observed mean difference, $\mathrm{DIF}_{\mathrm{obs}}=0.26 \mathrm{~mol} \mathrm{~m}^{-2}$ day $\left.^{-1}, p<0.001\right)$. Herb-layer vegetation attributes did not differ statistically at the site level (Table 2.1, Fig. 2.1), although mean cover was more than $50 \%$ greater in exclosures. Sapling density was significantly greater in exclosures $\left(\mathrm{DIF}_{\mathrm{obs}}\right.$ $=1.12 \mathrm{~m}^{2}, p<0.001$ ) (see Appendix 2.C, Table 2.C.1). A complete list of species including mean cover by site can be found in Appendix 2.C, Table 2.C.2.

Monte Carlo randomization tests of the $90^{\text {th }}$ percentile were not significantly different for ammonium $\left(\mathrm{DIF}_{\mathrm{obs}}=0.31 \mathrm{mg} \mathrm{L}^{-1} \mathrm{~g}^{-1}\right.$ resin, $\left.p=0.895\right)$, nitrate $\left(\mathrm{DIF}_{\mathrm{obs}}=0.28\right.$ $\mathrm{mg} \mathrm{L}^{-1} \mathrm{~g}^{-1}$ resin, $p=1$ ), or total nitrogen ion availability $\left(\mathrm{DIF}_{\mathrm{obs}}=0.49 \mathrm{mg} \mathrm{L}^{-1} \mathrm{~g}^{-1}\right.$ resin, $p$ $=0.807)$.

\subsubsection{Spatial analyses}

Complexity of spatial variance structure, as determined by model complexity and type, differed according to deer access for cover and diversity but not for nitrogen availability or under-canopy radiation (Table 2.2). Cover exhibited a nonlinear, exponential spatial variance structure at deer access and exclosure sites, although the inclusion of a nugget parameter significantly improved the model in deer exclosures (Table 2.2). A nugget parameter represents unexplained variance either due to significant spatial variance at separation distances smaller than the sampling grain ( $1 \mathrm{~m}$ in our study) or sampling error (Goovaerts 1998). Assuming equal sampling error at each site, this finding suggests significant spatial variance at very fine $(<1 \mathrm{~m})$ scales in deer exclosures, but not at deer access sites. Spatial variance structure of diversity was more complex in access sites compared to exclosures (Table 2.2, Fig. 2.2). Direct under-canopy radiation was best represented by nonlinear, Gaussian models with a nugget in deer access and exclosure sites, with little difference in parameter estimates according to deer access. Other variables were best represented by 2-parameter exponential models (Table 2.2). No 
semivariogram model estimated a sill $>1$ (Table 2.2), indicating spatial dependence even at the largest separation distance.

Differences in patch size associated with deer access can be examined by comparing the range of spatial dependence (Table 2.2, Fig. 2.2). The patch size of ammonium availability was $66 \%$ smaller in deer access sites compared to deer exclosures (range $=7.47 \mathrm{~m}$ vs. $3.30 \mathrm{~m}$; Table 2.2, Fig. 2.2). Cover patch size was $64 \%$ smaller in deer access sites (range $=16.49 \mathrm{~m}$ vs. 5.98m; Table 2.2, Fig. 2.2). Nitrate availability and diffuse under-canopy radiation exhibited weaker spatial variance structure at deer access sites compared to exclosures as evidenced by the selection of simpler, linear models for access sites (Table 2.2). The patch size of these variables likely exceeds the maximum distance of our models because their nugget parameters ( $y$-intercept) are less than 1 and their slopes are small. Diversity patch size in deer exclosures may also exceed the maximum distance for the same reason. The patch size of direct under-canopy radiation was $26 \%$ smaller in access sites compared to exclosures (Table 2.2, Fig. 2.2), which is less of a difference compared to ammonium and cover.

In comparing patch size among variables, cover and diversity were similar to ammonium availability and direct under-canopy radiation at deer access sites. Within deer exclosures the patch size of cover was similar to diffuse under-canopy radiation. Direct under-canopy radiation and nitrate availability patch sizes were similar, and smaller, than ammonium (Table 2.2, Fig. 2.2).

\subsection{Discussion}

Our results support the hypothesis that ungulate excreta maintain more complex spatial patterns in soil nitrogen resources and herb-layer cover at a spatial extent of 1-20m. Where deer are present, the spatial pattern of nitrogen availability may be patchier despite a lack of difference in mean stand level nitrogen availability. Although many studies have documented the growth-stimulating effects of ungulate excreta, particularly urea-nitrogen (e.g. Steinauer and Collins 1995, Peek and Forseth 2003), our study demonstrates that it can affect spatial heterogeneity in resource availability and herb-layer cover at spatial scales relevant to herb-layer communities of temperate forests. 
In forest ecosystems light availability is another resource, in addition to nutrient availability, that limits herb-layer growth (Gilliam and Roberts 2003) and influences the spatial patterning of herb-layer communities (Scheller and Mladenoff 2002). In our study light seemed to have a greater influence on the spatial patterning of cover where deer were absent, but not where they were present. At deer access sites the sapling layer was greatly reduced compared to exclosures, presumably due to dormant season browsing (Frelich and Lorimer 1985, Rooney et al. 2000, Witt and Webster 2010). Consequently, the spatial patterning of diffuse under-canopy radiation was less complex. However, spatial patterning of herb-layer cover and diversity exhibited smaller patch sizes despite less complex spatial patterning in diffuse radiation. In deer exclosures the sapling layer and spatial pattern of diffuse radiation were more complex, and the patch size of cover closely resembled that of diffuse radiation. Deer have been known to homogenize plant communities across spatial gradients of resource availability via browsing (e.g. Holmes and Webster 2011), but in our study deer appear to have increased heterogeneity in understory cover.

Although deer and other ungulates are generally regarded as homogenizers of plant communities (e.g. Rooney et al. 2004, Webster et al. 2005, Rooney 2009), deer effects on vegetation operate within a broader ecological context (Schmitz and Sinclair 1997). Until recently studies of deer impacts were limited to case studies where a problem was perceived a priori, making them susceptible to pseudoreplication (Côté et al. 2004). Several recent studies have highlighted the broader ecological function of deer in forest ecosystems. For example, Royo et al. (2010) found that at intermediate deer densities browsing interacts with other disturbances, such as fire and gap creation, to increase plant diversity. Deer exclusion reduced diversity by allowing fast-growing, palatable plant species to dominate the community following disturbance. Long-term exclusion of browsing ungulates can lead to a similar outcome even in the absence of disturbance (Perrin et al. 2011). Deer abundance is often thought of as an indicator of deer impacts, however, deer impacts also depend on the abundance of palatable plants (Schmitz and Sinclair 1997) and landscape context (Rutherford and Schmitz 2010, Hurley et al. 2012). At the landscape scale deer may function as vectors for nutrient transport from ecosystems of greater nutrient availability to those of lower nutrient 
availability (Seagle 2003, Bump et al. 2009a, Abbas et al. 2012). At finer scales ungulate carcasses can create nutrient hotspots that affect forest and prairie plant community composition (Towne 2000, Bump et al. 2009b).

Our results likely apply to other deer populations and ungulate species because of seasonally (or diurnally) dynamic aggregations, dispersals, and migrations common to these species. Consequently, our study highlights the importance of seasonal timing in both resource inputs and herbivory to the outcome of complex feedbacks between herbivores and the spatial distribution of resources. A plant's ability to compensate for herbivory depends on the timing of herbivory and nutrient availability, in addition to competition with other plants (Maschinski and Whitham 1989). Hemlock forests are used by deer primarily for winter cover rather than food. Deer migrate from hemlock stands to more productive habitats as severe winter weather subsides (Verme 1973), so that most deer herbivory occurs during the dormant season (Frelich and Lorimer 1985, Rooney et al. 2000, Witt and Webster 2010). Due to seasonal deer use, much of the deer-source nitrogen inputs occur during winter and enter the soil pool as a pulse during spring snowmelt. Spring ephemerals and soil microorganisms would benefit directly from these nitrogen pulses, and capture nitrogen for later uptake by summer vegetation (Zak et al. 1990). Plant community heterogeneity has previously been linked to deer use in remnant hemlock stands (Jensen et al. 2011). Therefore, we hypothesize that the seasonal decoupling of ungulate habitat use and plant growth has allowed understory plants the opportunity to respond to ungulate-excreted nitrogen additions without greater risk of being consumed by ungulates. The patchy spatial distribution of deer excreta results in patches of increased vegetation growth, increasing the spatial heterogeneity of vegetation cover.

The impact of deer on neighborhood scale heterogeneity in nitrogen availability and herb-layer cover suggests a link between fine scale and landscape scale processes. Ungulates select habitat patches at coarse landscape-level scales, whereas impacts on vegetation occur at the scale of individual plants (Weisberg et al. 2006). Consequently, landscape configuration can modulate the impact of ungulate herbivory on vegetation at a given ungulate density (Hurley et al. 2012). In the northern hardwood-hemlock forest mosaic of our study, deer selection of conifer-dominated winter habitat is influenced by 
landscape context in addition to stand level variables (Witt et al. 2012). In our study seasonal patterns in deer habitat selection reduced cover of large seedlings and saplings that grow above the snowpack. Growing season herbivory may be reducing cover in access sites relative to exclosures, although the reduction was not statistically significant. Moderate levels of growing season herbivory may result in greater diversity even if cover is reduced (Royo et al. 2010). If moderate growing season herbivory reduces total cover, deer may still increase heterogeneity through patchy nitrogenous waste deposition (Steinauer and Collins 1995, Augustine and Frank 2001), trampling (Heckel et al. 2010), and selective herbivory (Augustine and McNaughton 1998). Similarly, the patch size of nitrogen and cover may vary over the landscape with changes in deer use, linking fine scale and coarse scale processes. This question could be explored further by incorporating deer access sites across a gradient of deer densities.

Our failure to detect nitrogen hotspots at deer access sites does not compromise our conclusion that ungulate excreta increase spatial heterogeneity in nitrogen availability. First, most of the deer-excreted nitrogen measured by ion-exchange resin bags was deposited during winter and passed through the snowpack before reaching the soil. This process is likely to have increased the area affected by an excretion event while making its patch boundary more diffuse and difficult to detect. Second, resin bags were buried for several weeks after snowmelt. Other nitrogen inputs during this time may have masked deer-excreted nitrogen. We retrieved resin bags during the vegetation survey to ensure that we measured the nitrogen available to the observed vegetation community. Third, it is highly unlikely that we placed a resin bag in the exact location that a deer urinated or defecated during winter 2010-11 given that fecal pellets occurred in $<3 \%$ of the sampled area. The observed differences in spatial patterns may be the cumulative result of deer-excreted nitrogen inputs over multiple seasons.

Browsing ungulates may be an important source of spatial heterogeneity in forest ecosystems. Human activities are greatly altering nitrogen cycling in many temperate forest ecosystems, and one outcome is the homogenization of nitrogen availability (Gilliam 2006). Atmospheric nitrogen deposition levels are less elevated in the northern Great Lakes region where our study took place compared to more industrialized areas (e.g. Gilliam 2006, 2007), although they are greater than annual nitrogen sequestration by 
plants (Talhelm et al. 2012). Herb-layer communities contain much of the biodiversity in temperate forests (Gilliam 2007), but biodiversity declines as a result of nitrogen saturation and homogenization (Gilliam 2006). Therefore, ecological processes that increase spatial heterogeneity of nitrogen availability and are scale-dependent are important to maintaining biodiversity. Ungulates may increase or decrease heterogeneity of these processes depending on ecological context, and may be an important component of unaltered forest nitrogen cycles as they are in grasslands (e.g. McNaughton 1985, Augustine et al. 2003). Although ungulate exclosures are useful for restoring vegetation in many cases, they may not be effective at restoring spatial patterns of resource availability.

Our results demonstrate that forest ungulates can create complex spatial patterns in soil nitrogen, a critical and limiting terrestrial resource. The ecological importance of this effect is contingent upon the scale of inference and the seasonal timing of ungulate impacts relative to ecosystem response. Ungulates are common in forest ecosystems, and may be an important ecological link between fine scale and landscape scale processes that are further modulated by seasonally dynamic habitat selection. Our main results highlight the general need to examine (and re-examine) the dynamic role of ungulate species in affecting ecosystem processes. Questions of scale and heterogeneity are prominent in ecology because they provide a link between ecosystem and animal ecology that advances conservation science (Levin 1992, Ritchie 2010, Loreau 2010). Forest ungulate ecology may be better understood when viewed within a broad ecological context that includes scale, heterogeneity, and ecosystem processes. 


\subsection{Tables and Figures}

Table 2.1: Results of Monte Carlo randomization tests (1000 permutations; $\alpha=0.05$ ) comparing site-level means grouped by access to white-tailed deer (Odocoileus virginianus) ( $n=3$ each).

\begin{tabular}{lcccc}
\hline \multicolumn{1}{c}{ Variable } & $\begin{array}{c}\text { Access } \\
{[\text { mean }(\mathrm{SE})]}\end{array}$ & $\begin{array}{c}\text { Exclosure } \\
{[\text { mean }(\mathrm{SE})]}\end{array}$ & $\mathrm{DIF}_{\text {obs }}{ }^{\mathrm{a}}$ & $P^{\mathrm{b}}$ \\
\hline Ammonium $\left(\mathrm{mg} \cdot \mathrm{L}^{-1} \cdot[\mathrm{g} \mathrm{resin}]^{-1}\right)$ & $2.71(0.36)$ & $2.70(0.40)$ & 0.01 & 1.000 \\
Nitrate $\left(\mathrm{mg} \cdot \mathrm{L}^{-1} \cdot[\mathrm{g} \mathrm{resin}]^{-1}\right)$ & $1.37(0.46)$ & $1.09(0.35)$ & 0.29 & 0.517 \\
Total N ion $\left(\mathrm{mg} \cdot \mathrm{L}^{-1} \cdot[\mathrm{g} \mathrm{resin}]^{-1}\right)$ & $4.09(0.63)$ & $3.79(0.30)$ & 0.30 & 0.682 \\
Direct UCR $\left(\mathrm{mol} \cdot \mathrm{m}^{-2} \cdot \mathrm{day}^{-1}\right)$ & $5.58(0.49)$ & $7.28(0.39)$ & 1.69 & 0.107 \\
Diffuse UCR $\left(\mathrm{mol} \cdot \mathrm{m}^{-2} \cdot \mathrm{day}^{-1}\right)$ & $0.80(0.10)$ & $1.06(0.08)$ & 0.26 & $<0.001$ \\
Total UCR $\left(\mathrm{mol} \cdot \mathrm{m}^{-2} \cdot \mathrm{day}^{-1}\right)$ & $6.39(0.54)$ & $8.34(0.43)$ & 1.95 & 0.094 \\
Herb cover $(\%)$ & $15.4(3.9)$ & $36.0(4.7)$ & 20.6 & 0.097 \\
$S$ & $4.26(0.53)$ & $5.97(0.98)$ & 1.71 & 0.084 \\
$H^{\prime}$ & $0.93(0.091)$ & $1.26(0.15)$ & 0.33 & 0.104 \\
$E$ & $0.72(0.03)$ & $0.75(0.01)$ & 0.03 & 0.373 \\
Seedling density $\left(\mathrm{seedlings} \cdot \mathrm{m}^{-2}\right)$ & $3.95(1.40)$ & $6.42(1.81)$ & 2.47 & 0.377 \\
Sapling density $\left(\mathrm{saplings} \cdot \mathrm{m}^{-2}\right)$ & $0.01(0.01)$ & $1.13(0.57)$ & 1.12 & $<0.001$ \\
\hline
\end{tabular}

Notes: Data are from six eastern hemlock (Tsuga canadensis) stands in the Upper

Peninsula of Michigan, USA. Total $\mathrm{N}$ ion equals the sum of ammonium concentration and nitrate concentration. UCR stands for under-canopy (solar) radiation. Total UCR equals the sum of direct UCR and diffuse UCR. Herb cover is the percent cover of herblayer vegetation $<1.0 \mathrm{~m}$ height. $S$ is species richness; $H^{\prime}$ is Shannon's diversity index; $E$ is evenness; based on a sample plot size of $1 \mathrm{~m}^{2}$.

${ }^{\mathrm{a}}$ observed difference $=\mid$ mean $_{\mathrm{access}}-$ mean $_{\text {exclosure }} \mid$.

${ }^{\mathrm{b}} P=$ proportion of $\mathrm{DIF}_{\text {sim }} \geq \mathrm{DIF}_{\mathrm{obs}}$, where $\mathrm{DIF}_{\text {sim }}$ are from a randomized distribution. 


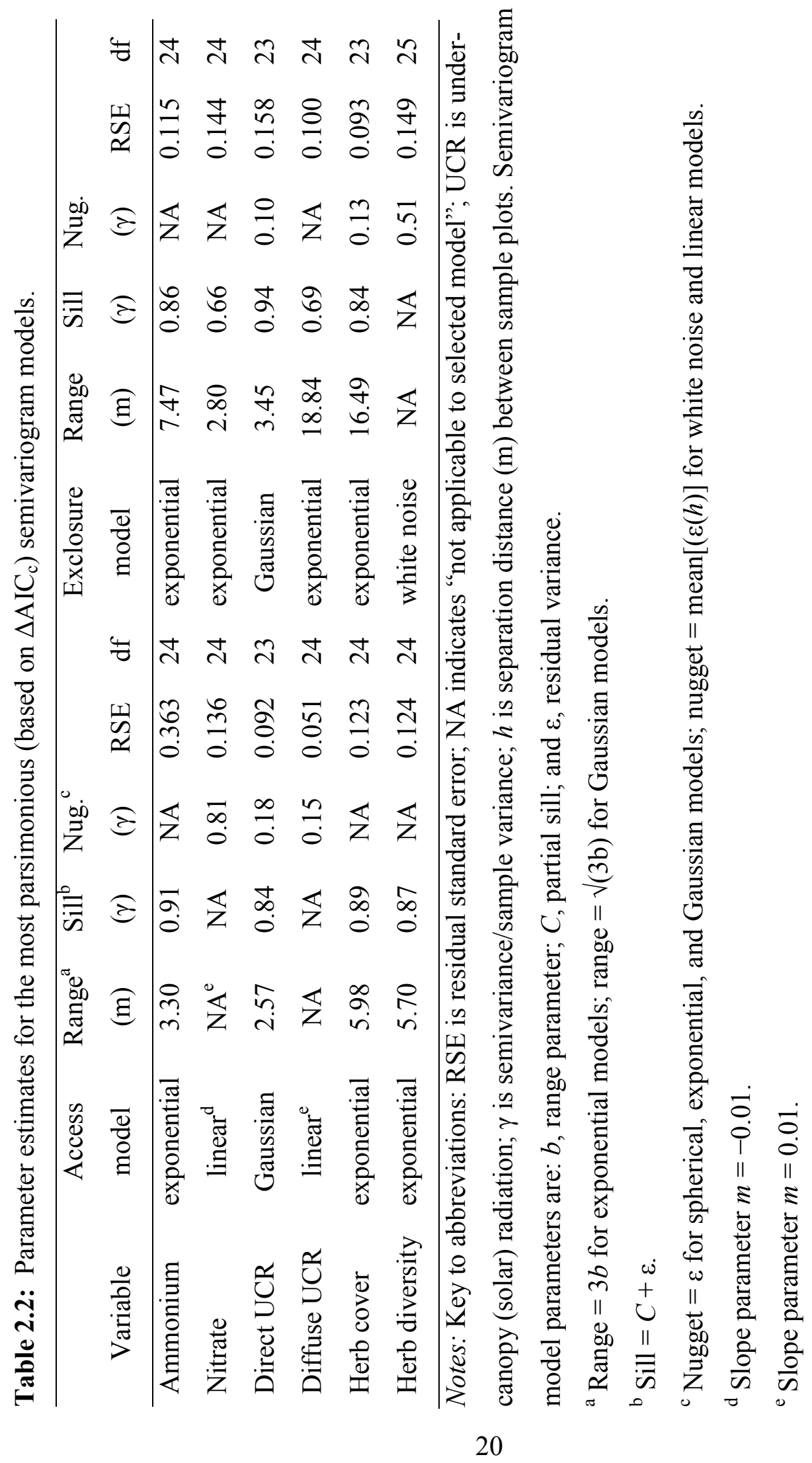



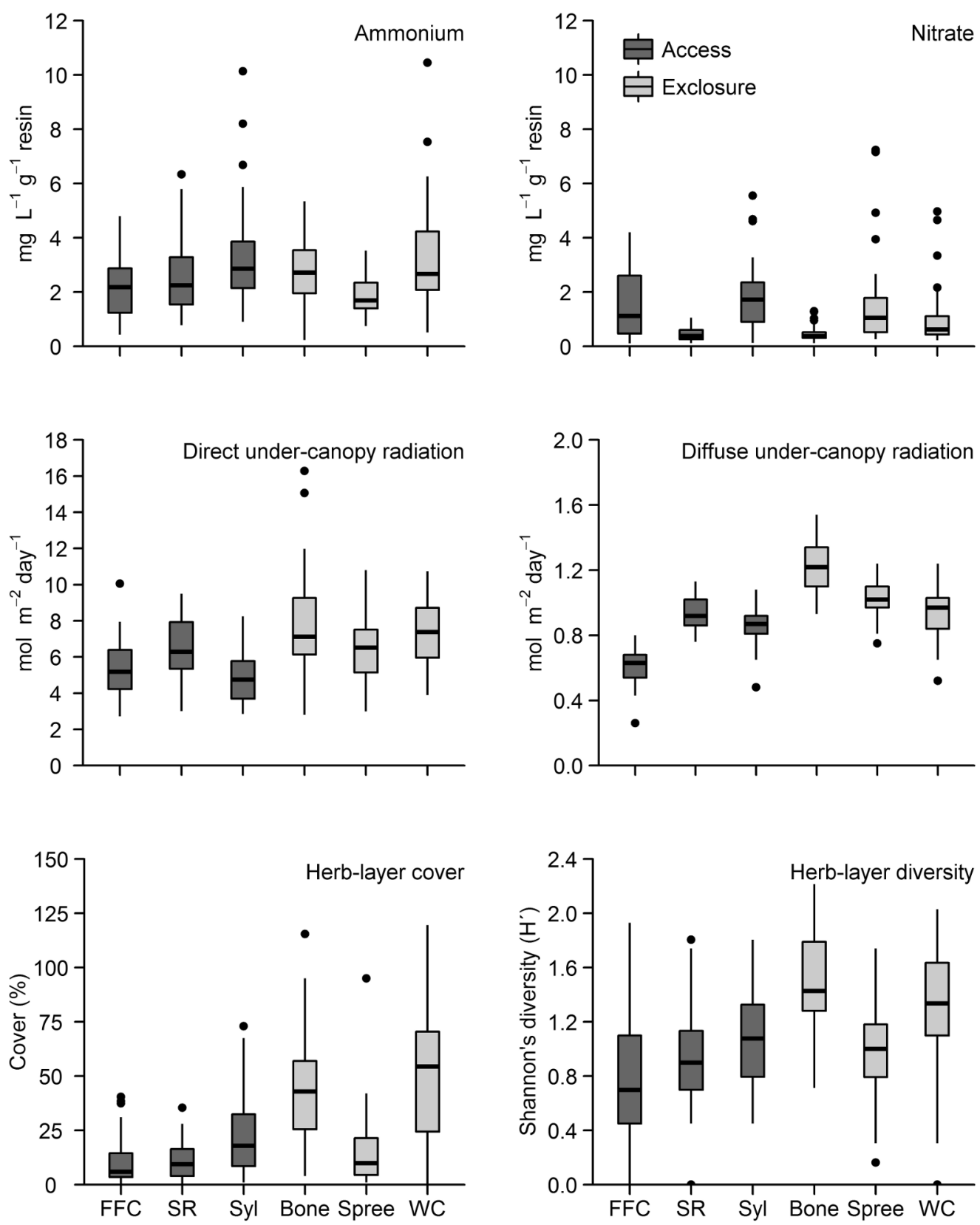

Figure 2.1: Boxplots of each variable by site in eastern hemlock (Tsuga canadensis) stands in the Upper Peninsula of Michigan, USA. In each box, the dark middle line represents the median, and the upper and lower extents of the box represent the $75^{\text {th }}$ and $25^{\text {th }}$ percentiles, respectively. Lines extend to 1.5 times the interquartile range (difference of $75^{\text {th }}$ and $25^{\text {th }}$ percentiles). Black circles indicate outliers. Site name abbreviations: FFC, Ford Forestry Center; SR, Silver River; Syl, Sylvania; Bone, Boneyard; WC, Walton Creek. 

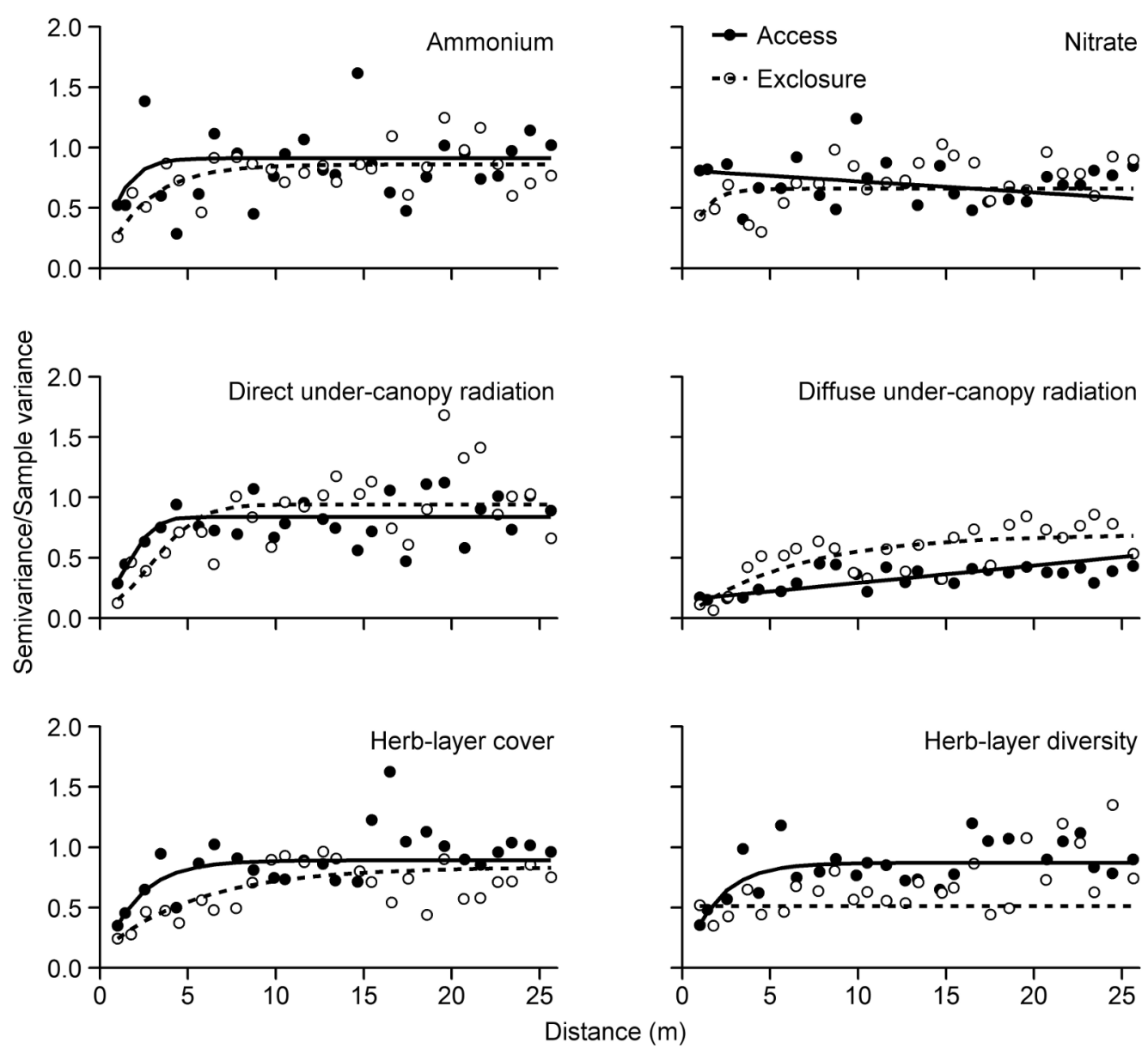

Figure 2.2: Empirical semivariograms (circles) and modeled semivariograms (lines), grouped according to white-tailed deer (Odocoileus virginianus) access (open circles, deer have access; solid circles, exclosures inhibit deer access). A semivariogram displays changes in semivariance ( $y$-axis) over increasing separation distances between sample plots ( $x$-axis). See Table 2.2 for model identification and parameter estimates. 


\subsection{Appendix 2.A. Ottawa National Forest and Ford Forestry}

\section{Center study site information}

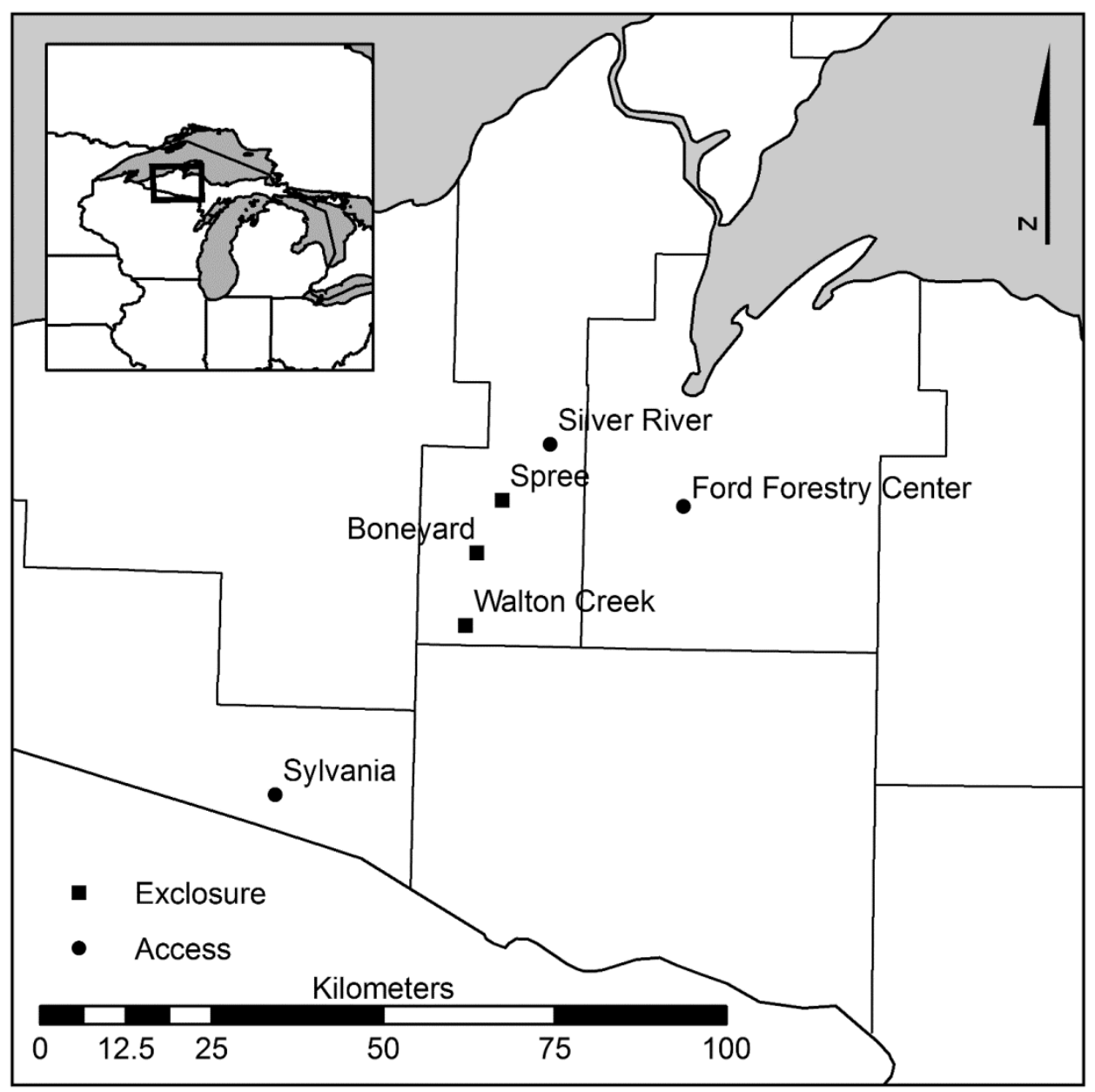

Figure 2.A.1: Study sites were located in remnant eastern hemlock (Tsuga canadensis) stands in the Upper Peninsula of Michigan, USA. Three sites (Boneyard: 46²32'29.73"N, 8852'51.14"W, Spree: 46³6'40.48"N, 8850'06.71"W, and Walton Creek:

$\left.46^{\circ} 26^{\prime} 45.41^{\prime \prime} \mathrm{N}, 88^{\circ} 53^{\prime} 56.12^{\prime \prime} \mathrm{W}\right)$ were enclosed within a $2 \mathrm{~m}$ tall deer exclosure fence.

The three other sites (Ford Forestry Center: 46³6'29.98"N, 88²9'24.45"W, Silver River: $46^{\circ} 41^{\prime} 09.11^{\prime \prime} \mathrm{N}, 88^{\circ} 44^{\prime} 47.01^{\prime \prime} \mathrm{W}$, and Sylvania: $46^{\circ} 13^{\prime} 18.16^{\prime \prime} \mathrm{N}, 89^{\circ} 15^{\prime} 03.09^{\prime \prime} \mathrm{W}$ ) were accessible to deer. 


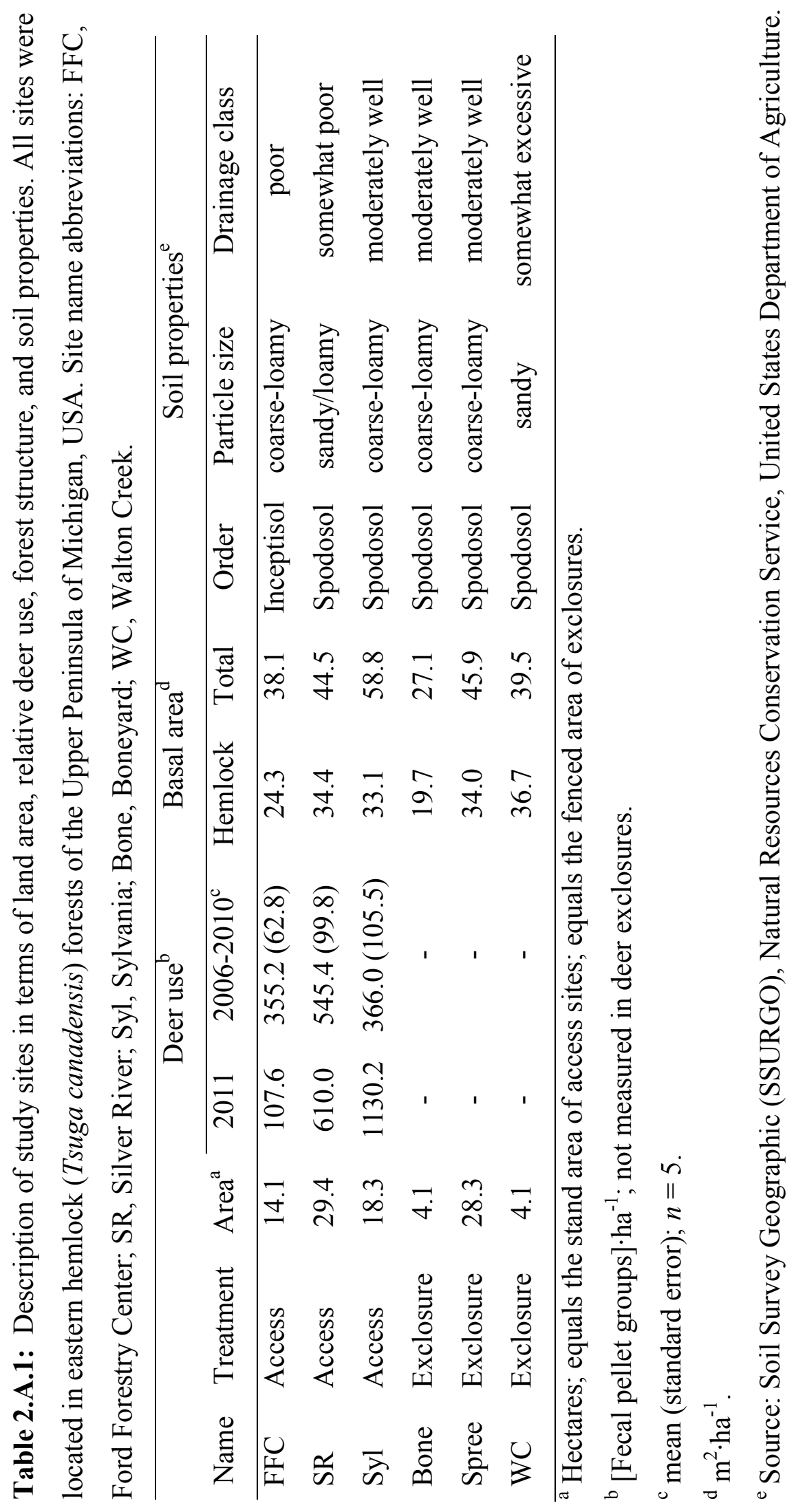




\subsection{Appendix 2.B. Detailed description of deer use survey, ion- exchange resin bag, and spatial variance modeling methodologies}

Appendix 2.B.1. Stand level deer use surveys, 2006-2011

Winter deer use in the access sites was measured by fecal pellet group counts each May from 2006-2011. Pellet groups were counted by 2 observers in the same $9.29 \mathrm{~m}^{2}$ circular plots each year. Sampling intensity varied by stand size, with 20 plots at Sylvania and Ford Forestry Center and 30 plots at Silver River. Sample plot locations were chosen randomly using ArcView 3.3 Random Point Generator extension (Jenness Enterprises, Flagstaff, AZ, USA). Previously deposited pellet groups were removed from sample plots in 2005, and during the May pellet counts thereafter (Witt and Webster 2010).

\section{Appendix 2.B.2. Ion-exchange resin bag methodology}

Bags of resin beads were constructed using $7.4 \mathrm{~mL}$ (approx. 5.0g) of Dowex ${ }^{\circledR}$ Marathon ${ }^{\mathrm{TM}}$ MR-3 hydrogen and hydroxide form resin beads (Sigma-Aldrich, St. Louis, MO, USA). The resin beads were sealed in $12.7 \times 12.7 \mathrm{~cm}$ squares of nylon-lycra fabric (80\% nylon, 20\% lycra) using a water-insoluble glue (Giblin et al. 1994, Harpole and Tilman 2007). Ammonium and nitrogen ions were extracted from ion-exchange resins using $2 \mathrm{M} \mathrm{KCl}$, and the concentrations of each ion were determined colorimetrically (Skogley and Dobermann 1996, Harpole and Tilman 2007). The four resin bags from each quadrant were pooled for analysis. They were shaken together in $100 \mathrm{~mL}$ of $2 \mathrm{M} \mathrm{KCl}$ at $180 \mathrm{rpm}$ for 1 hour, and then remained stationary for an additional hour. Extracts were vacuum filtered using Whatman $\# 2$ filter paper, and $35 \mathrm{~mL}$ of extract was refrigerated for less than 1 week before analysis. Extracts were analyzed colorimetrically for ammonium and nitrate concentration using a Perstorp 3550 EnviroFlow System (Rapid Flow Analyzer). Resin beads were air-dried and weighed post-extraction. Nitrogen ion availability was expressed as $\mathrm{mg} \mathrm{L}^{-1} \mathrm{~g}^{-1}$ resin for statistical analysis. 


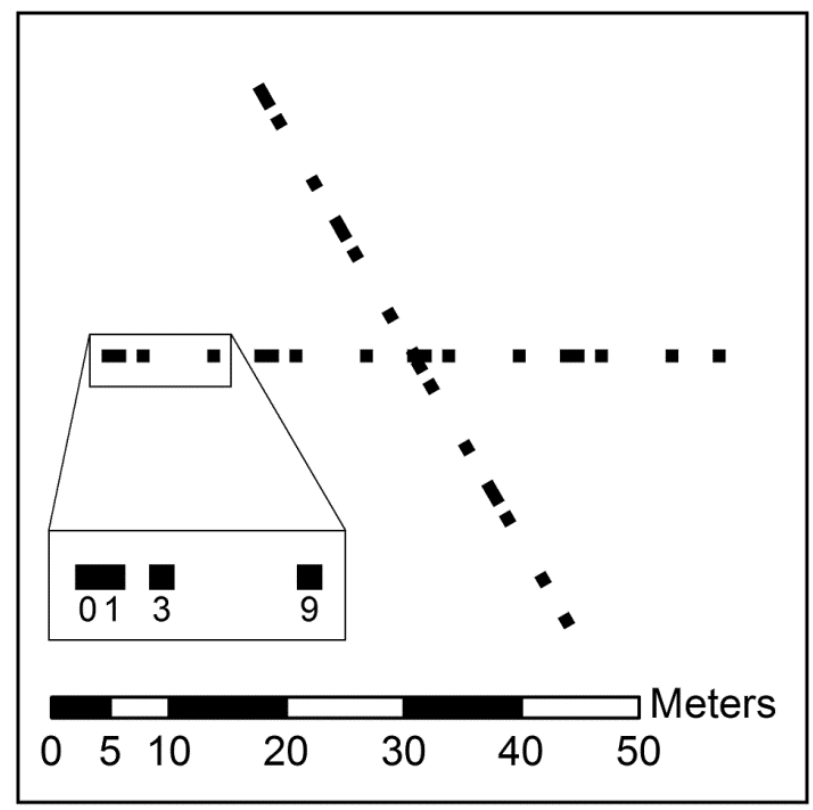

Figure 2.B.1: Sample quadrants were arranged in a cyclical sampling design to maximize sampling efficiency for spatial variance modeling (Clinger and Van Ness 1976, Scheller and Mladenoff 2002). 
2.9. Appendix 2.C. Data tables describing understory tree height class distributions and mean cover of herb-layer species by site

Table 2.C.1: Total number of woody stems, by height class $(\mathrm{cm})$, which were counted in $331 \mathrm{~m}^{2}$ quadrants at each site. Note that height class intervals are unequal.

\begin{tabular}{lcccc}
\hline \multirow{1}{*}{ Site } & \multicolumn{4}{c}{ Height class (cm) } \\
\cline { 2 - 5 } & $0-25$ & $25-50$ & $50-100$ & $100-300$ \\
\hline Access & 39 & 1 & 0 & 0 \\
$\quad$ Ford Forestry Center & 152 & 0 & 0 & 0 \\
$\quad$ Silver River & 195 & 1 & 0 & 0 \\
$\quad$ Sylvania & & & & 0 \\
Exclosure & 274 & 25 & 6 & 0 \\
$\quad$ Boneyard & 239 & 3 & 3 & 3 \\
Spree & 27 & 15 & 4 & 3 \\
Walton Creek & & &
\end{tabular}




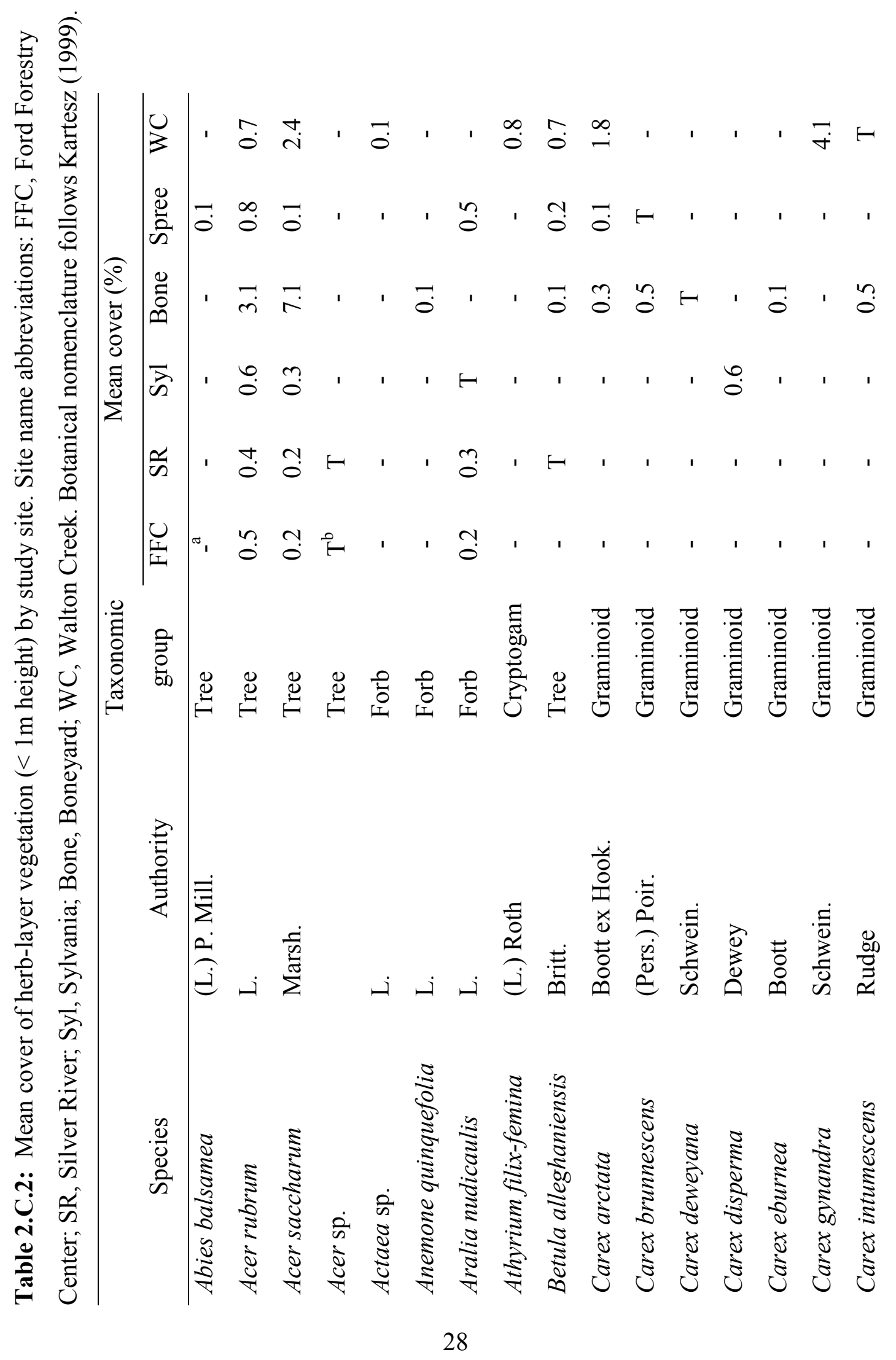




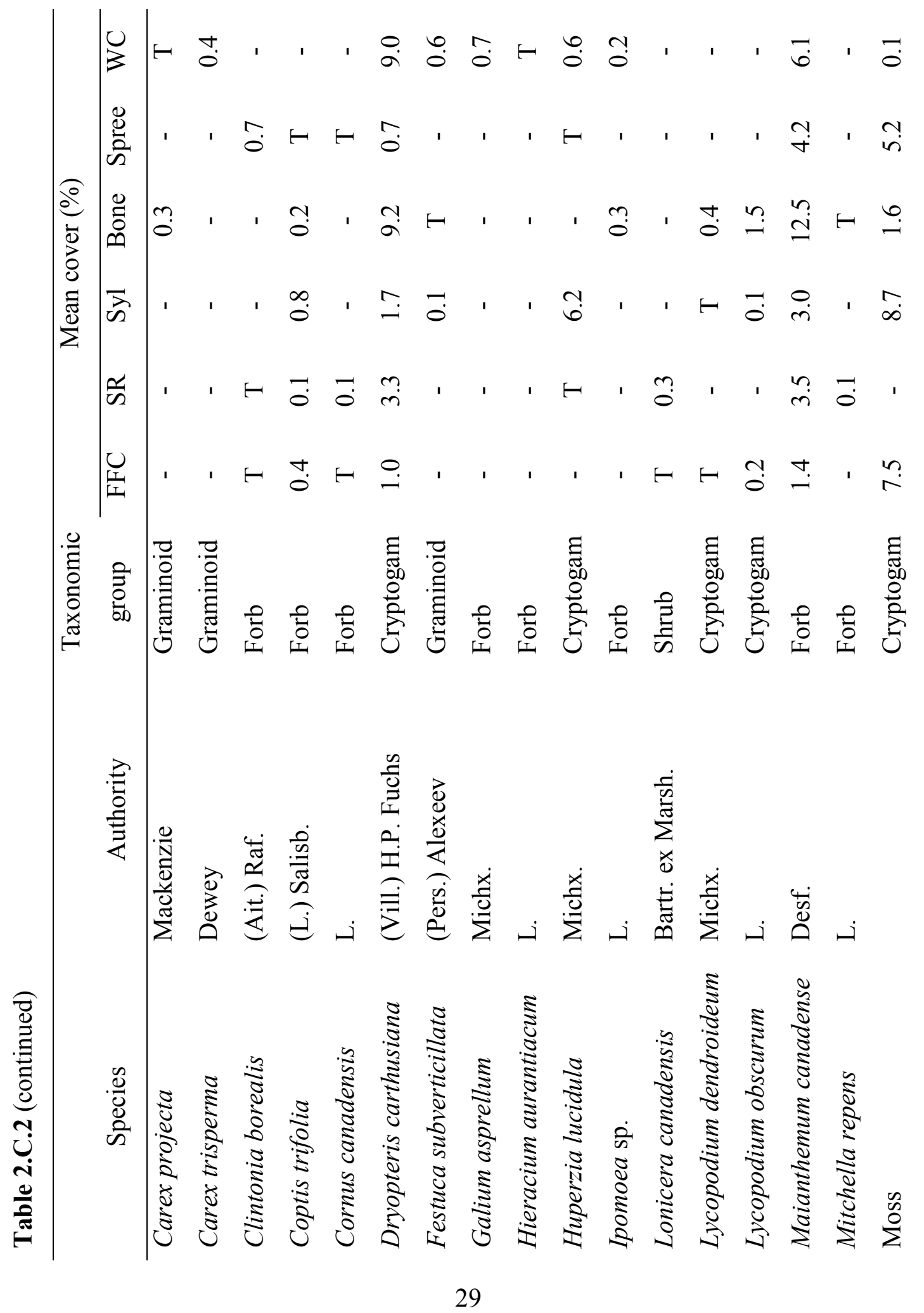




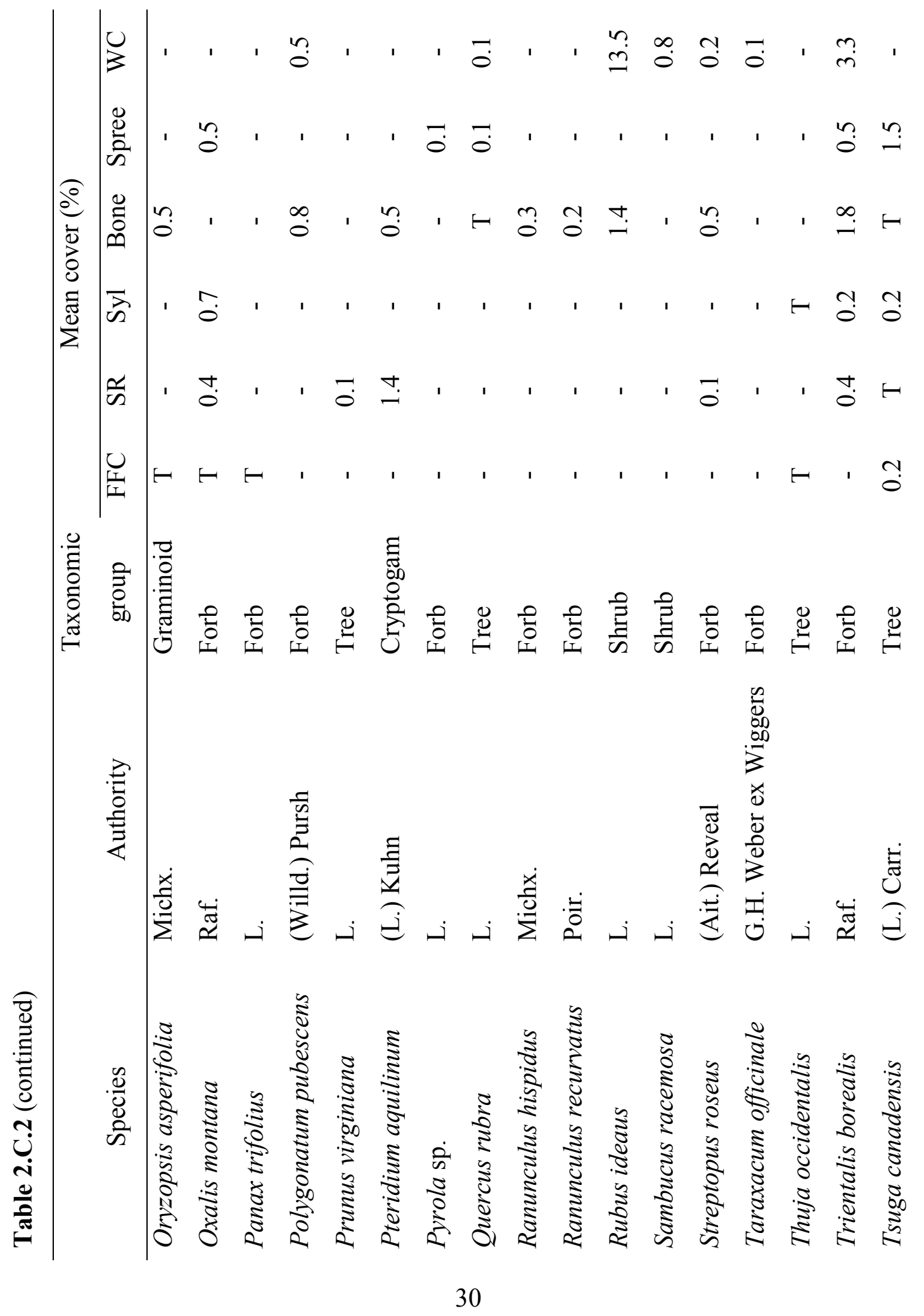




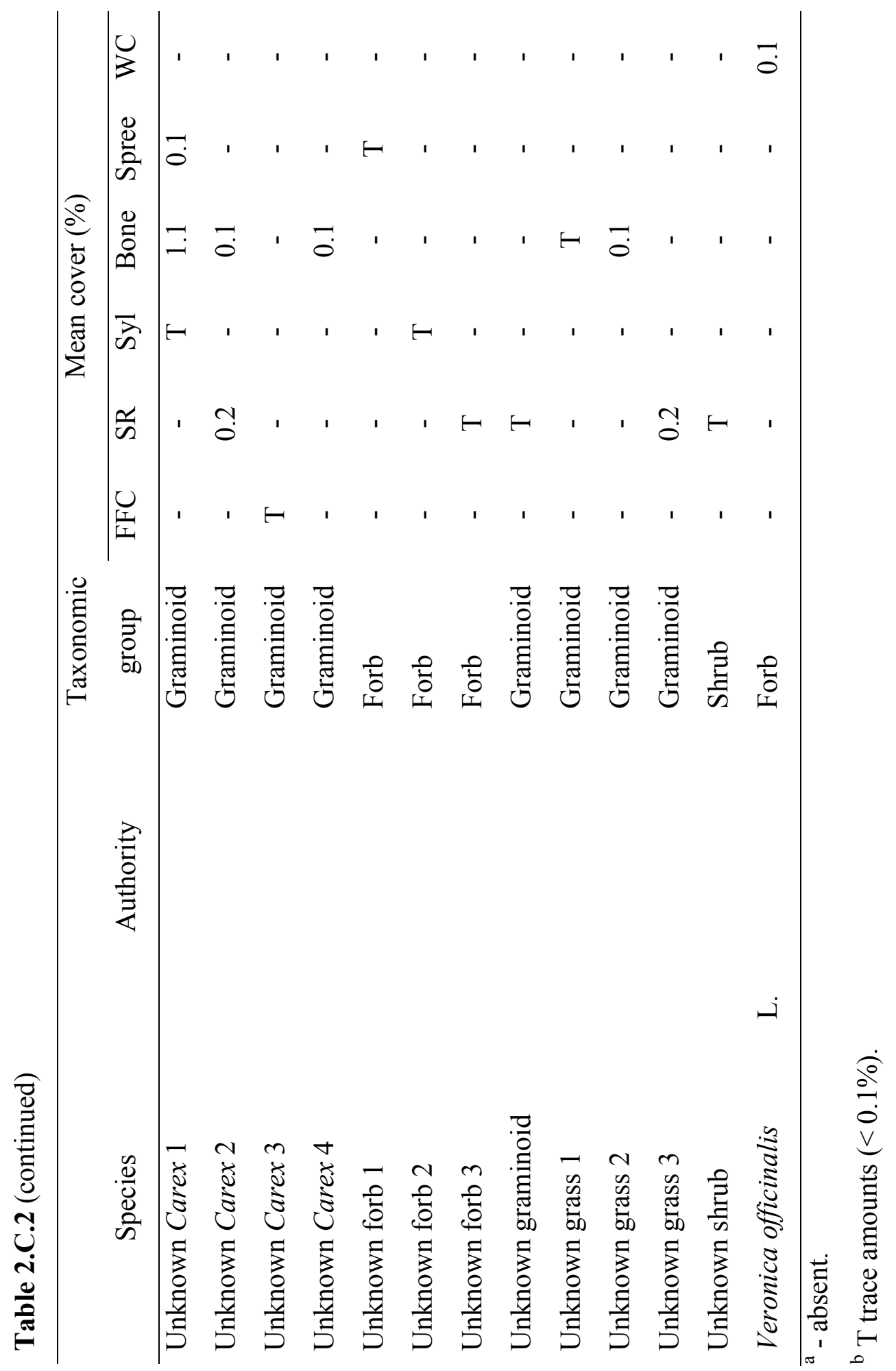




\section{A migratory ungulate facilitates cross-boundary nitrogen transport in forested landscapes ${ }^{2}$}

\subsection{Abstract}

Forest ungulates are likely to impact ecosystems in a number of ways. Most studies have focused on consumptive effects that may cascade to other components of the ecosystem, and they tend to be motivated by harvest management or the mitigation of undesired effects on vegetation. In this study we demonstrate that white-tailed deer (Odocoileus virginianus), a forest ungulate common in eastern North America, may directly increase availability of $\mathrm{N}$, a limiting nutrient in temperate forests. In the northern temperate forests where our study took place, deer forage in a variety of habitat types during the warm seasons, and migrate to stands of eastern hemlock (Tsuga canadensis) during winter. We used annual spring fecal pellet counts conducted over eight consecutive years in 39 remnant hemlock stands to model deer-excreted $\mathrm{N}$ deposition. The effect of deer on $\mathrm{N}$ availability is highly variable at the spatial extent of a forest stand (1-60 ha) based on habitat selection by deer. In stands that receive moderate levels of deer use, deer-excreted $\mathrm{N}$ influx was $25-50 \%$ of atmospheric $\mathrm{N}$ deposition for the region, whereas deer-excreted $\mathrm{N}$ consistently exceeded atmospheric $\mathrm{N}$ in stands at the upper range of deer use. However, unlike atmospheric $\mathrm{N}$, deer-excreted $\mathrm{N}$ is concentrated in biogeochemical hotspots at finer spatial scales. Deer select patches of winter cover based on landscape position, browse availability, and snow depth. Whereas the first two factors are relatively consistent at annual time scales, snow depth is stochastically variable and results in temporal and spatial variability in deer use, and therefore deer-excreted N. As deer migrate from warm season habitats to hemlock stands for the winter, they are likely transporting an ecologically meaningful amount of $\mathrm{N}$, which they excrete as urinary and fecal $\mathrm{N}$. These $\mathrm{N}$ inputs are likely to increase the quantity and quality of available forage, increasing the likelihood that deer will use the stand in the future. Generalist species like

\footnotetext{
${ }^{2}$ This chapter is in preparation for submission to the peer-reviewed journal Oikos. Authors include B. D. Murray, C. R. Webster, and J. K. Bump.
} 
forest ungulates are likely to exhibit a wide range of both direct and indirect interactions with ecosystem processes depending on ecological context.

\subsection{Introduction}

Ungulate herbivores that inhabit fragmented forested landscapes are among the terrestrial animals that are thriving despite widespread anthropogenic landscape modification. Humans have indirectly facilitated an unprecedented increase in many ungulate populations by reducing large predator populations, increasing habitat fragmentation, and managing ungulate populations for recreational hunting (Weisberg and Bugmann 2003). In North America, the undesirable aspects of ungulate overabundance were recognized by the early $20^{\text {th }}$ century (Leopold et al. 1947). Ungulate ecology has been studied extensively from the perspectives of harvest management (Roseberry and Woolf 1991), damage to agricultural and forest products (Tilghman 1989; Putman 1996), and conservation of natural areas (Côté et al. 2004). A growing number of studies have begun to describe the broader ecological functions of forest ungulates within complex ecosystems and landscapes (e.g. Ritchie et al. 1998; Seagle 2003; Jensen et al. 2011; Abbas et al. 2012; Bressette et al. 2012; Murray et al. 2013).

Whereas grassland ungulates are considered to be an important component of nutrient cycles, particularly N (McNaughton 1985; Augustine et al. 2003), the potential influence of ungulates on $\mathrm{N}$ cycling in forest ecosystems is currently being developed. Ungulate herbivores accumulate $\mathrm{N}$ from plant tissues and then excrete both organic and inorganic $\mathrm{N}$ as waste products. Individual excretion events result in greater productivity of the affected vegetation (Steinauer and Collins 1995; Peek and Forseth 2003). The amount of $\mathrm{N}$ excreted by an ungulate herbivore increases with the $\mathrm{N}$ content of consumed plants and the herbivore's body size (Hobbs 1996). When ungulates form large aggregations, their $\mathrm{N}$ additions can be as large as $27 \%$ of net mineralized $\mathrm{N}$ in grassland systems (Frank et al. 1994). Due to the low $\mathrm{N}$ content of their forage, smaller body size, and social structure, forest ungulates are thought to have little direct effects on forest $\mathrm{N}$ budgets (Pastor et al. 2006). 
Certain aspects of forest ungulate ecology suggest that under certain conditions, which are not uncommon, forest ungulates may increase soil $\mathrm{N}$ availability at ecologically significant levels. Forest ungulates form small family groups (DeYoung and Miller 2011) with highly conserved habitat use patterns (Stewart et al. 2011). In patches of preferred habitat, strong aggregative effects result in ecological impacts that exceed expectations based on the number of ungulates on the landscape. Also, temperate forests tend to have relatively low $\mathrm{N}$ mineralization rates, and $\mathrm{N}$ is often a limiting nutrient in temperate forests (Vitousek and Howarth 1991). Even relatively small $\mathrm{N}$ inputs could affect understory herbs in concentrated patches, or hotspots (Gilliam 2007; Bump et al. 2009b). Lastly, as forest ungulates move between different habitat patch types, they are moving $\mathrm{N}$ among different forest types where $\mathrm{N}$ may cycle at different rates. Whether or not an animal increases $\mathrm{N}$ availability in a given ecosystem depends in part on whether they are cycling nutrients or importing them from a different ecosystem (De Mazancourt et al. 1998). Cross-boundary movements are likely to result in $\mathrm{N}$ flux from less productive to more productive habitat types (Augustine et al. 2003; Seagle 2003; Abbas et al. 2012).

In this paper we explore the impacts of white-tailed deer (Odocoileus virginianus) on $\mathrm{N}$ availability in patches of preferred winter cover that are dominated by eastern hemlock (Tsuga canadensis). Deer in colder climates forage widely across the landscape during the warmer seasons, and then migrate to conifer-dominated habitat patches during winter (Verme 1973; Euler and Thurston 1980; Van Deelen et al. 1998). Winter habitat is less abundant than warm season habitat, resulting in dense aggregations of overwintering deer. Hemlock patches, which are preferred by deer, exhibit slower N cycling dynamics compared to adjacent forest types dominated by northern hardwoods (Mladenoff 1987; Ferrari 1999; Campbell and Gower 2000; Lovett et al. 2004). After estimating deer use in 39 remnant hemlock patches for eight consecutive winters, we modeled deer-excreted $\mathrm{N}$ deposition over space and time based on annual fecal pellet counts. We hypothesized that deer-excreted $\mathrm{N}$ deposition during winter is large enough to be an ecologically significant contribution to the $\mathrm{N}$ budget of a hemlock stand. Furthermore, recurring spatial patterns in deer winter habitat use were hypothesized to result in consistent patterning of deersource $\mathrm{N}$ deposition at whole-stand and within-stand spatial scales. In this study system, 
inter-annual variation in deer use is driven in part by variation in snow depth, a stochastic abiotic factor. Therefore, we compare spatial and temporal variation in deer-excreted $\mathrm{N}$ to that of snow depth.

\subsection{Methods}

\subsubsection{Fecal pellet counts}

Our study area consisted of 39 remnant hemlock stands, ranging in area from 0.04 ha to 59.6 ha, located in the western Upper Peninsula of Michigan, USA. Winter deer use was estimated by counting fecal pellet groups in fixed area $\left(9.29 \mathrm{~m}^{2}\right)$ circular plots. The sampling network was established in 2005, and pellets were counted each spring from 2006-2013. Although pellet counts were conducted only once each year, they primarily represent winter use due to seasonal habitat selection patterns of deer in the region (Verme 1973; Van Deelen et al. 1998). A grand total of 590 plots were distributed over the 39 sites in groups of 3, 5, 10, 20, or 30 per site. Sampling intensity varied according to site area. Detailed descriptions of site selection, characteristics, and sampling design are published in Witt and Webster (2010) and Witt et al. (2012).

Sites that were not selected by deer over the eight-year study period were excluded from the following data analysis. Our questions focused on the intensity of use in selected habitats, rather than habitat selection. We hypothesized that the intensity of use would vary based on snow conditions (Morrison et al. 2003; Witt et al. 2012), whereas selection of winter habitat patches depends on landscape context, browse availability, and tradition (Van Deelen et al. 1998; Witt et al. 2012). Second, including the unselected sites would have created numerical complications by adding a large number of zeroes in the response variable. Therefore, it was reasonable to exclude unselected sites and further group selected sites by intensity of deer use. We considered a site to be a "deeryard" if at least one pellet group was observed during the eight-year study period ( $N=35$ sites; $n=562$ plots). A "persistent deeryard" was defined as a site where at least one pellet group was observed during each year ( $N=20$ sites; $n=385$ plots). 


\subsubsection{Modeling deer-excreted $\mathrm{N}$ deposition}

Annual site-level, deer-excreted $\mathrm{N}$ deposition was estimated by determining the mean $\mathrm{N}$ content per excretion event (urine and feces), then using the fecal pellet counts to scale up to the site level. Mean fecal $\mathrm{N}$ content was estimated from 45 pellet groups collected from a subset of 15 sites during March 2008 (complete methods are published in Jensen et al. 2011). For $\mathrm{N}$ excreted as urine, we assumed that deer tend to urinate and defecate concurrently (Wallmo 1981), and an average urination event contains $5.0 \mathrm{~g}$ of N (Mysterud et al. 2001; Jensen et al. 2011). Deer-excreted N was computed on an annual, per-hectare basis using fecal pellet count data.

\subsubsection{Spatial patterning in deer habitat use}

Based on our hypothesis that spatial patterning in deer habitat use is conserved over time, we predicted that the temporal frequency of pellet groups would be greater in high-use areas than expected by chance. To test this prediction, we used a $G$-test for independence (Gotelli and Ellison 2004) to determine if the observed, plot-level frequency distribution of pellet group counts differed from a Poisson distribution. The Poisson distribution was chosen because it represents an expected random frequency distribution for count data. If the $P$-value of the $G$-test was less than $0.05\left(\mathrm{X}^{2}\right.$ distributed), then we rejected the null hypothesis that observed pellet count frequencies were random.

\subsubsection{Deer use and snow depth}

We used an information-theoretic modeling approach to examine our hypothesis that site-level deer use varies over space and time according to snow pack duration and depth. We obtained daily snow depth estimates from 16 November through 15 May (14 May during leap years) for each study year (2005-2013) from the National Operational Hydrologic Remote Sensing Center (2004). Snow depth data were processed, projected, and then extracted at each sample plot location using ArcGIS 10.1 (ESRI 2012). Snow depth variables included the annual mean, median, and $95^{\text {th }}$ percentile for the potential yarding period of 1 December - 30 April. To estimate snow cover duration, we 
determined the first and last days of the season in which snow depth was greater than thresholds of $0.2 \mathrm{~m}, 0.4 \mathrm{~m}$, and $0.6 \mathrm{~m}$, as well as the number of days greater than each threshold.

Generalized linear mixed-effects models were developed for estimating fecal pellet counts at the plot level based on snow depth and snow duration parameters. The most parsimonious model was selected based on Akaike's AIC (Burnham and Anderson 2002, Zuur et al. 2009). Each model was based on a Poisson distribution with log link, which corresponded with the distribution of the pellet count data. Generalized linear mixed-effects models were fit using the Laplace approximation (Raudenbush et al. 2000) in the R package LME4 (R 2012). Given the nested structure of the sampling design, we compared fixed effects models to mixed effects models where the $y$-intercept, and the $y$ intercept and slope, varied according to site. Mixed effects models included an offset to account for uneven numbers of plots at each site. First, a model was selected that included only a snow depth or snow duration parameter. Then a final model was constructed that included the selected depth and duration parameter, and compared to the simpler models to confirm that information was gained by including both parameters. Independent variables were standardized $\left[\left(x_{i}-\operatorname{mean}\left(x_{i}\right)\right) /\right.$ standard deviation $\left.\left(x_{i}\right)\right]$ for the full model because depth and duration were measured on different scales. In each set of model selection, we started with fixed effects models, and then allowed the $y$-intercept and the $y$-intercept and slope to vary according to site. This order of analysis prevents unnecessarily modeling variance associated with the fixed effects as a random effect (Zuur et al. 2009).

\subsection{Results}

\subsubsection{Deer-excreted N deposition}

Deer-excreted $\mathrm{N}$ deposition at the site/year level ranged from $0 \mathrm{~kg} \cdot \mathrm{ha}^{-1}$ to 12.4 $\mathrm{kg} \cdot \mathrm{ha}^{-1}$ (Table 3.1). Among the stands considered to be deeryards, the mean \pm standard error was $2.1 \pm 0.2 \mathrm{~kg} \cdot \mathrm{ha}^{-1}$, and the median was $1.2 \mathrm{~kg} \cdot \mathrm{ha}^{-1}$ (Table 3.1). The persistent deeryards group had a mean \pm standard error of $3.0 \pm 0.2 \mathrm{~kg} \cdot \mathrm{ha}^{-1}$, and median of 2.0 $\mathrm{kg} \cdot \mathrm{ha}^{-1}$ (Table 3.1). Annual atmospheric $\mathrm{N}$ deposition (total dry and wet) in the region 
was approximately $5 \mathrm{~kg} \cdot \mathrm{ha}^{-1}$ during 2009-2011 (http://epa.gov/castnet). Therefore, persistently-used deeryards typically received a non-trivial amount of $\mathrm{N}$ from the nitrogenous wastes of deer (Fig. 3.1A).

\subsubsection{Habitual spatial patterns in habitat use}

The hypothesis that deer-excreted $\mathrm{N}$ would be concentrated in hotspots, and that the spatial distribution of hotspots would be conserved over time, was supported. Observed frequency distributions of plot-level deer use were independent of expected Poisson distributions for deeryards $(G=186.4, d f=8, P<0.001)$ and persistent deeryards $(G=96.7, d f=8 ; P<0.001)$. The frequency of plots that contained pellet groups during zero years, or five or more years, was greater than expected due to chance in both the deeryards and persistent deeryards groups (Fig. 3.2). In the deeryards group, the frequency of plots with pellet groups during one, two, or three years out of eight was lower than the expectation (Fig. 3.2A). For the persistent deeryards group, pellet group frequencies of two and three were lower than expected (Fig. 3.2B). Mean annual deerexcreted $\mathrm{N}$ flux was negatively correlated with the pellet count coefficient of variation (Fig. 3.3), indicating that plots within persistent deeryards where deer use was consistent over time received the greatest levels of deer-excreted N. Some areas received on average up to four times more $\mathrm{N}$ from deer deposition than atmospheric deposition, even in less preferred deeryards (Fig. 3.4).

\subsubsection{Deer use and snow depth}

Generalized linear mixed effects models of deer fecal pellet counts and annual snow conditions supported the hypothesis that deer use would be greater in plots and years of greater mean annual snow depth (Fig. 3.1B). Snow duration also influenced deer use, but deer use was greater in years where the depth threshold was reached later in the season, rather than earlier as we predicted. The most parsimonious model of deer use based on snow depth included mean annual snow depth and allowed the slope and intercept to vary according to site (Table 3.2). The best model based on snow duration included the first day after 16 November in which snow depth exceeded $0.4 \mathrm{~m}$, as well as 
a random slope and intercept for site (Table 3.2). Placing both of these variables in the same model resulted in a better fit than either single-variable model (Table 3.2), suggesting that both snow depth and duration contribute to explaining spatial and temporal variance in deer use. The correlation between the variables, natural logtransformed, was not large $\left(r^{2}=0.39\right)$. In the combined model with standardized independent variables, deer use increased with mean annual snow depth $\left(b_{1}=0.21 ; P<\right.$ $0.001)$ and the first day greater than $0.4 \mathrm{~m}$ depth $\left(b_{2}=0.17 ; P=0.004\right)$.

\subsection{Discussion}

Our hypotheses that seasonally-dependent spatial patterns in deer habitat use result in a cross-boundary $\mathrm{N}$ subsidy, and that spatial and temporal variability in the subsidy is dependent in part on snow depth, were supported. Based on our allometric modeling results at the stand scale (1-60 ha), deer-excreted $\mathrm{N}$ regularly matched or exceeded that of mean annual atmospheric $\mathrm{N}$ deposition in highly used deeryards, and often approached $25-50 \%$ of atmospheric deposition in deeryards that were used persistently. At neighborhood scales $\left(<10 \mathrm{~m}^{2}\right)$, mean annual deer-excreted $\mathrm{N}$ was more than four times that of atmospheric $\mathrm{N}$ in preferred habitat patches. There was a great deal of within-stand heterogeneity in deer-excreted $\mathrm{N}$ even where deer use was low, whereas atmospheric $\mathrm{N}$ deposition occurs more evenly at both stand and neighborhood scales (Gilliam 2006). Temporal and spatial variability in deer use, and therefore deer-excreted $\mathrm{N}$, was influenced by snow depth and duration, a stochastic environmental factor.

A key implication of our study is that ungulates may subsidize soil $\mathrm{N}$ pools in habitat patches that are selected for reasons other than foraging. High densities of forest ungulates tend to decrease $\mathrm{N}$ availability in forest ecosystems due to feedbacks among consumption rates, plant communities, and belowground processes (Bardgett and Wardle 2003; Pastor et al. 2006). However, subsidies may occur if $\mathrm{N}$ excretion exceeds assimilation in a given habitat type, and ungulates are likely to have a negative $\mathrm{N}$ balance in non-foraging habitats when they travel between foraging and non-foraging patches on a daily basis (Holdo et al. 2007). For example, in our study system, dense coniferdominated canopies function as winter cover for white-tailed deer by capturing more 
snow than deciduous forest types, reducing snow depth on the ground (Euler and Thurston 1980). The dense canopy also precludes many preferred deer forage species from the understory, and the saplings that establish receive heavy browsing pressure (Frelich and Lorimer 1985; Rooney et al. 2000; Witt and Webster 2010). When weather allows, deer move between cover and forage habitats, where woody browse is more abundant but snow is deeper, on a daily basis (Rongstad and Tester 1969). Ungulatefacilitated $\mathrm{N}$ fluxes have been associated with daily movements in other ecosystems (Augustine et al. 2003; Seagle 2003; Abbas et al. 2012).

Seasonal movements and metabolic changes of northern ungulates are also likely to contribute to cross-boundary $\mathrm{N}$ subsidies. Currently, there is a disconnect between the amount of summer and winter habitat on the landscape due to a drastic reduction in hemlock cover (Mladenoff and Stearns 1993) and concomitant increase in the deer population (DelGiudice et al. 2009) during the $20^{\text {th }}$ century. Deer are dispersed across the landscape during summer and then aggregate in a diminishing amount of conifer cover during winter (Verme 1973; Van Deelen et al. 1998). Physiologically, overwintering deer are unable to maintain a positive energy balance due to the low nutritional value of woody browse and the high energetic cost of foraging in deep snow (Thompson et al. 1973). As deer advance through the stages of starvation, they catabolize tissues to obtain energy and nutrients, increasing the excretion of endogenous urea N (DelGiudice et al. 1987; DelGiudice and Seal 1988). Before a deer succumbs to starvation, urea $\mathrm{N}$ levels in urine can increase up to five times above normal levels (DelGiudice and Seal 1988). This endogenous $\mathrm{N}$ is accumulated during summer in other habitat types across the landscape, and excreted where deer aggregate during winter. Considering the reliance of deer on energy reserves for winter survival (Thompson et al. 1973), combined with the scarcity of available winter forage at our study sites (Witt and Webster 2010), much of the $\mathrm{N}$ excreted by deer likely originated in other forest types, at other times of year.

The magnitude and seasonal timing of the deer $\mathrm{N}$ subsidy makes it likely to affect $\mathrm{N}$ availability to plants and soil microbes. Hemlock patches exhibit slower $\mathrm{N}$ cycling dynamics, including a greater lignin/ $\mathrm{N}$ ratio and slower net $\mathrm{N}$ mineralization, compared to adjacent hardwood forests such as sugar maple (Acer saccharum) (Mladenoff 1987; Ferrari 1999; Campbell and Gower 2000; Lovett et al. 2004). Annual net N 
mineralization rates under hemlock-dominated canopies range from $60-100 \mathrm{~kg} \cdot \mathrm{ha}^{-1}$ (Mladenoff 1987; Ferrari 1999). Hemlock saplings have a greater N-use efficiency than sugar maple (Tripler et al. 2002), although both species are shade tolerant (Godman and Lancaster 1990; Godman et al. 1990). Feedbacks between N cycling rates and the ecology of hemlock and sugar maple have likely maintained stable patch boundaries in northern hardwood forests for up to 3,000 years (Frelich et al. 1993; Davis et al. 1998; Ferrari 1999). Northern temperate forests are generally N limited ecosystems (Vitousek and Howarth 1991), and additional $\mathrm{N}$ inputs would likely alter ground-layer and understory plant communities (Talhelm et al. 2013). Furthermore, deer-excreted $\mathrm{N}$ in winter cover habitats occurs as a pulsed resource subsidy as snow melts during early spring, a time of year that would increase plant growth and microbial uptake (Zak et al. 1990).

The interaction between deer habitat selection preferences and soil resources suggests the development of ecological feedbacks between selection and habitat quality. Sugar maple saplings, common at sites with high deer use (Witt and Webster 2010; Jensen et al. 2011), are luxury consumers of N, and deer select saplings with greater tissue $\mathrm{N}$ content (Tripler et al. 2002). Therefore, $\mathrm{N}$ fertilization through deer urine and feces, at the levels that we observed, is likely to increase both quantity and quality of available browse. This prediction is corroborated by Jensen et al. (2011), who reported that sugar maple sapling $\mathrm{N}$ pools in hemlock deeryards increase with deer use. More available browse at higher quality would consequently make the patch more suitable for winter deer habitat, resulting in a positive feedback loop.

Thinking of deer-excreted $\mathrm{N}$ influx at the stand level alone fails to capture the nuances of pattern and process, which are fundamental ecological concepts (Levin 1992). Habitat patch selection occurs at the scale of an individual animal's perception (Ritchie 2010). At finer spatial scales, deer-excreted $\mathrm{N}$ inputs are concentrated in locations within a habitat patch that are more preferred than others, resulting in biogeochemical hotspots. Deer select fine-scale patches within stands of winter cover based on variability in snow depth and forage availability (Morrison et al. 2003). The response of the herbaceous layer to $\mathrm{N}$ inputs occurs at the scale of an individual plant, so that spatial heterogeneity in soil $\mathrm{N}$ availability drives heterogeneity in vegetation cover (Murray et al. 2013) and 
community structure (Jensen et al. 2011). The consistently patchy spatial structure of deer-excreted $\mathrm{N}$ that we report is likely to increase the patchiness of understory vegetation.

The effect of spatial and temporal variability in snow depth on deer use of winter cover, and the variability in $\mathrm{N}$ fluxes that vary according to deer use, suggests that deer may mediate an indirect relationship between winter climate and soil resources. Our finding that the timing of snow depth accumulation to $0.4 \mathrm{~m}$ partly explains the variance in deer-excreted $\mathrm{N}$ corresponds with the depth at which deer movements become restricted (Verme 1973). Deer in the region select habitat patches based on landscape position, the availability of woody browse, and snow depth (Witt et al. 2012). The first two factors, landscape position and browse availability, are relatively consistent at annual time scales. Snow depth, on the other hand, is highly variable from year to year, resulting in inter-annual variability in deer use at the stand scale. Variance in deer-excreted $\mathrm{N}$ flux is large enough compared to net annual $\mathrm{N}$ mineralization in a hemlock stand to result in variance of plant productivity in a N-limited system.

White-tailed deer are among the most charismatic and well-studied organisms worldwide. They are a generalist species that inhabit in a wide range of habitats from southern Canada to Peru and northern Brazil (Smith 1991). Deer populations have thrived in post-settlement North America due to a number of ecological and sociological factors (McShea et al. 1997; Weisberg and Bugmann 2003). Deer population densities are at or above historic levels in many locations, with a myriad of undesirable ecological impacts having been reported (e.g. Russell et al. 2001, Rooney and Waller 2003). Consequently, much of what is known about deer ecology is tied to the natural resource management goals of increasing deer populations for recreational harvest and viewing, or mitigating the undesirable ecological impacts of deer "overabundance" (sensu McShea et al. 1997).

Despite their reputation as an overly-studied organism, forest ungulates represent an important global change phenomenon when viewed from a more holistic, ecological perspective. In addition to slowing rates of forest regeneration, damaging crops, and homogenizing plant communities, forest ungulates, like their grassland counterparts (McNaughton 1985; Augustine et al. 2003), interact with ecosystem processes. In grassland ecosystems, grazing ungulates function within the $\mathrm{N}$ cycle by consuming $\mathrm{N}$ in 
plant tissues and then excreting nitrogenous wastes in patches, often referred to as biogeochemical hotspots (Steinauer and Collins 1995; Augustine and Frank 2001). In forested ecosystems, browsing ungulates are generally thought to slow the rate of $\mathrm{N}$ cycling by selectively consuming the most palatable plant species, causing species that produce recalcitrant litter to increase (Pastor et al. 2006). Based on this grazer-browser dichotomy, studies of white-tailed deer ecology tend to focus on the consumptive effects rather than direct effects on ecosystem processes (cf. Seagle 2003; Jensen et al. 2011; Abbas et al. 2012).

\subsection{Conclusions}

The current study demonstrates that a generalist, wide-ranging species like whitetailed deer cannot be expected to function within each ecosystem in the same manner. With respect to the $\mathrm{N}$ cycle, herbivores function directly as recyclers of $\mathrm{N}$ from plant tissues to the soil $\mathrm{N}$ pool. Several indirect factors including deer population density, aggregative effects, seasonal or diel patterns in habitat use, and the ambient rate of $\mathrm{N}$ cycling can modify the outcome of this function. In the northern hardwood-hemlock forest mosaic where we conducted our study, deer migrate annually between productive warm season habitats and less productive cold season habitats that primarily function as cover (Verme 1973; Euler and Thurston 1980; Van Deelen et al. 1998). When winter weather is not too severe, deer move between conifer patches and deciduous forage habitats on a daily basis. This seasonal and diel coupling of habitat types likely results in a net influx of $\mathrm{N}$ into the less productive conifer stands, which is likely to increase the rate of $\mathrm{N}$ cycling. Such a transfer of nutrients by deer across a habitat boundary has been observed in agricultural landscapes where deer forage in crop fields and rest in adjacent woodlots (Seagle 2003; Abbas et al. 2012). Our study suggests that such a transfer can occur in landscapes that are less productive overall, but where there are clear boundaries between rates of ecological processes between different habitat types that are used by deer for different purposes. Deer and other ungulates certainly pose a number of management challenges for wildlife ecologists. Understanding ungulate ecology and developing effective management strategies depends in part on understanding the ecology 
of the whole ecosystem in addition to the ecology of the organism targeted by management. 


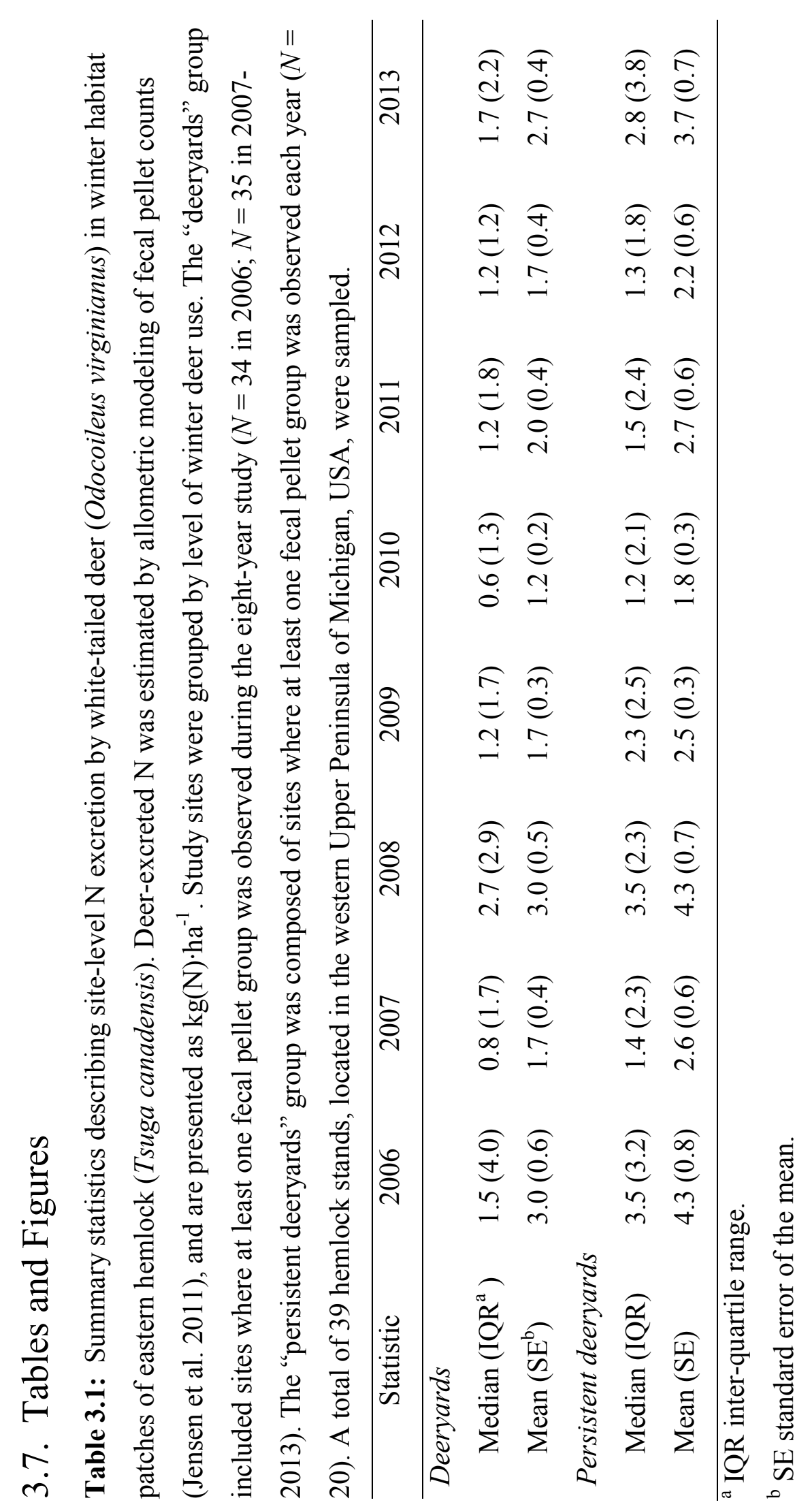




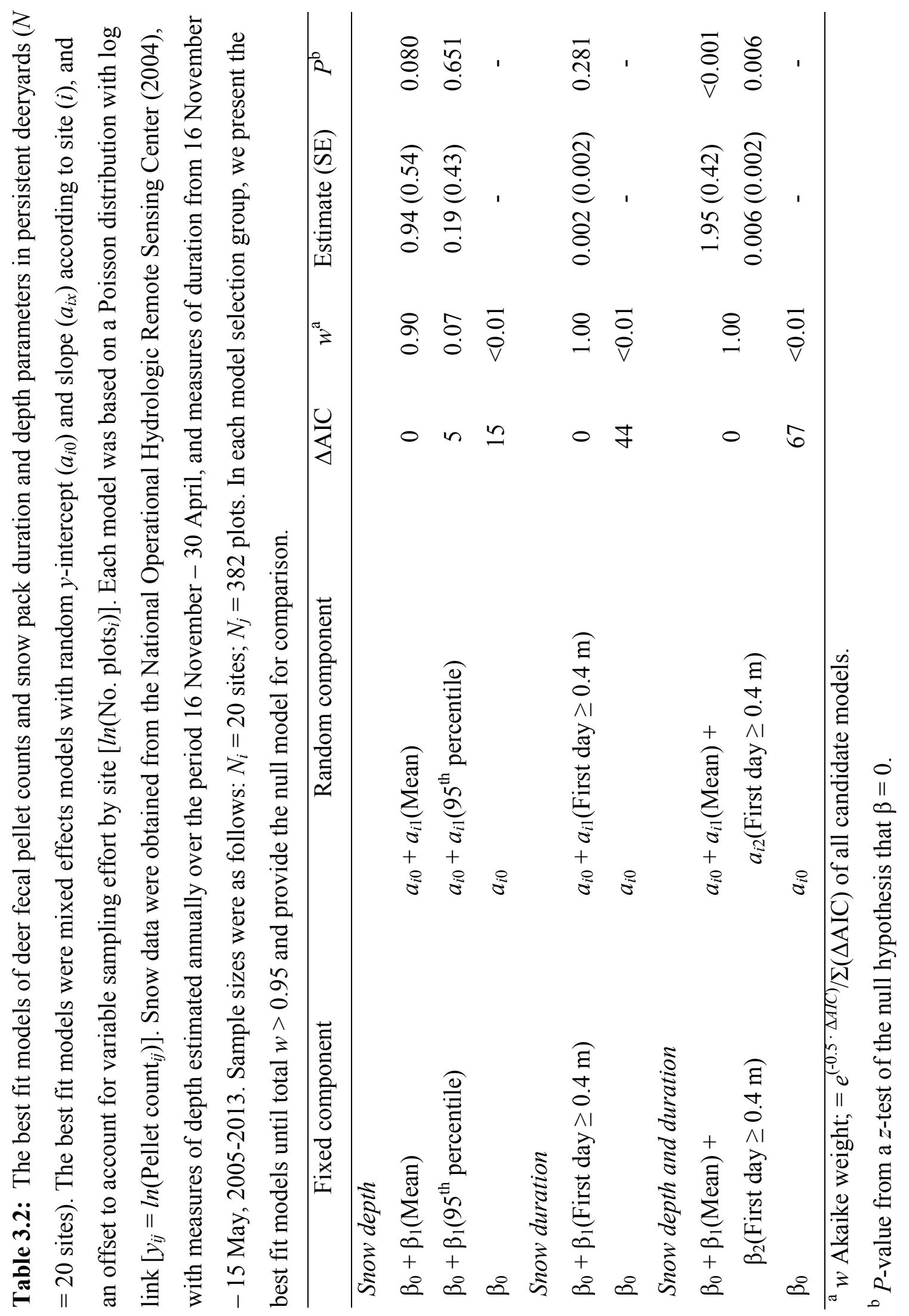



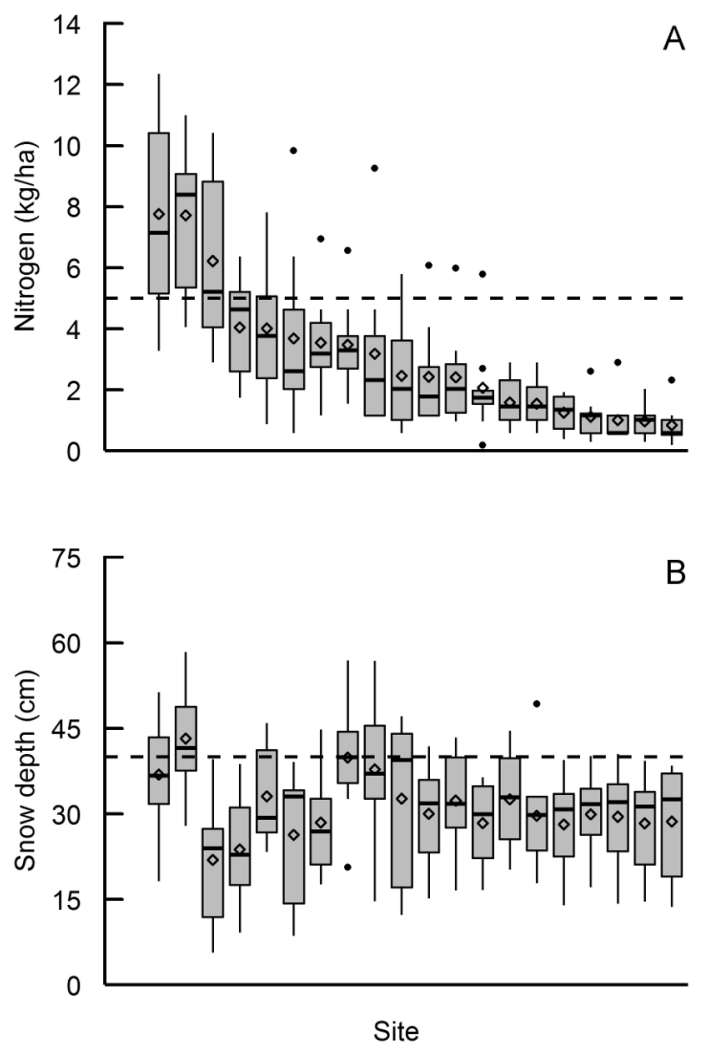

Figure 3.1: Boxplots depicting relationships between white-tailed deer (Odocoileus virginianus) excreted $\mathrm{N}$ flux (a) and mean annual snow depth, grouped by study site, during the potential winter deer yarding period (1 December - 30 April) (b). Deerexcreted $\mathrm{N}$ was estimated based on annual spring fecal pellet group counts conducted in 20 eastern hemlock (Tsuga canadensis) deeryards in the Upper Peninsula of Michigan, USA, over eight years (2006-2013). Snow data was obtained from the National Operational Hydrologic Remote Sensing Center (2004). The dashed line in plot $a$ shows annual $\mathrm{N}$ deposition from total wet and dry atmospheric sources during 2009-2011 (http://epa.gov/castnet), whereas the dashed line in plot $b$ represents the depth at which snow typically begins to increase the energetic cost of walking for deer $(40 \mathrm{~cm}$; Verme 1973). 


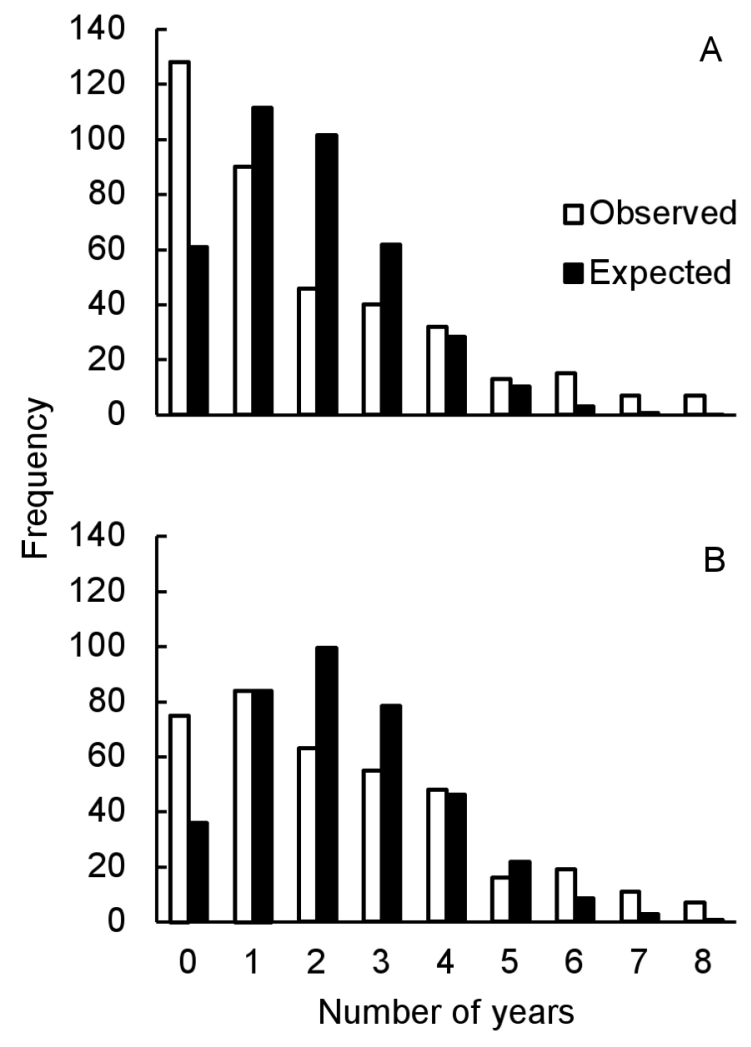

Figure 3.2: Frequency distributions based on the numbers of years in which one or more white-tailed deer (Odocoileus virginianus) fecal pellet groups were observed in the same sample plot. Expected values were estimated based on a Poisson distribution. A total of 39 eastern hemlock (Tsuga canadensis) stands were sampled annually from 2006-2013 using a network of 590, $9.29 \mathrm{~m}^{2}$ circular plots. The data presented in graph $(a)$ includes the stands where at least one pellet group was found during the eight-year sampling period ( $N=35$ stands; $n=$ plots), and graph $(b)$ includes stands where at least one pellet group was observed each year ( $N=20$ stands; $n=378$ plots $)$. 


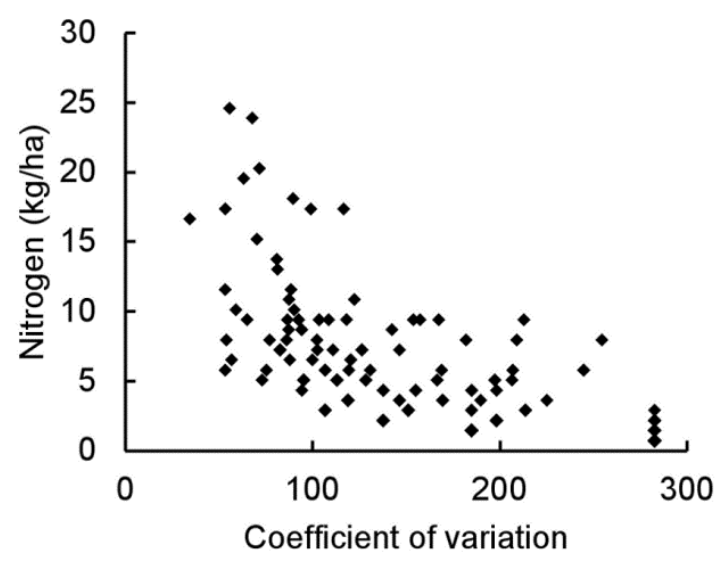

Figure 3.3: Within persistent eastern hemlock (Tsuga canadensis)-dominated deeryards, inter-annual consistency of white-tailed deer (Odocoileus virginianus) use at the plot level (pellet count coefficient of variation: $C V=100 \cdot($ standard deviation/mean)) was negatively correlated with deer-excreted N (Pearson's $r=-0.66 ; P<0.001 ; n=303$ ). Unused plots were excluded because $C V$ is undefined. 


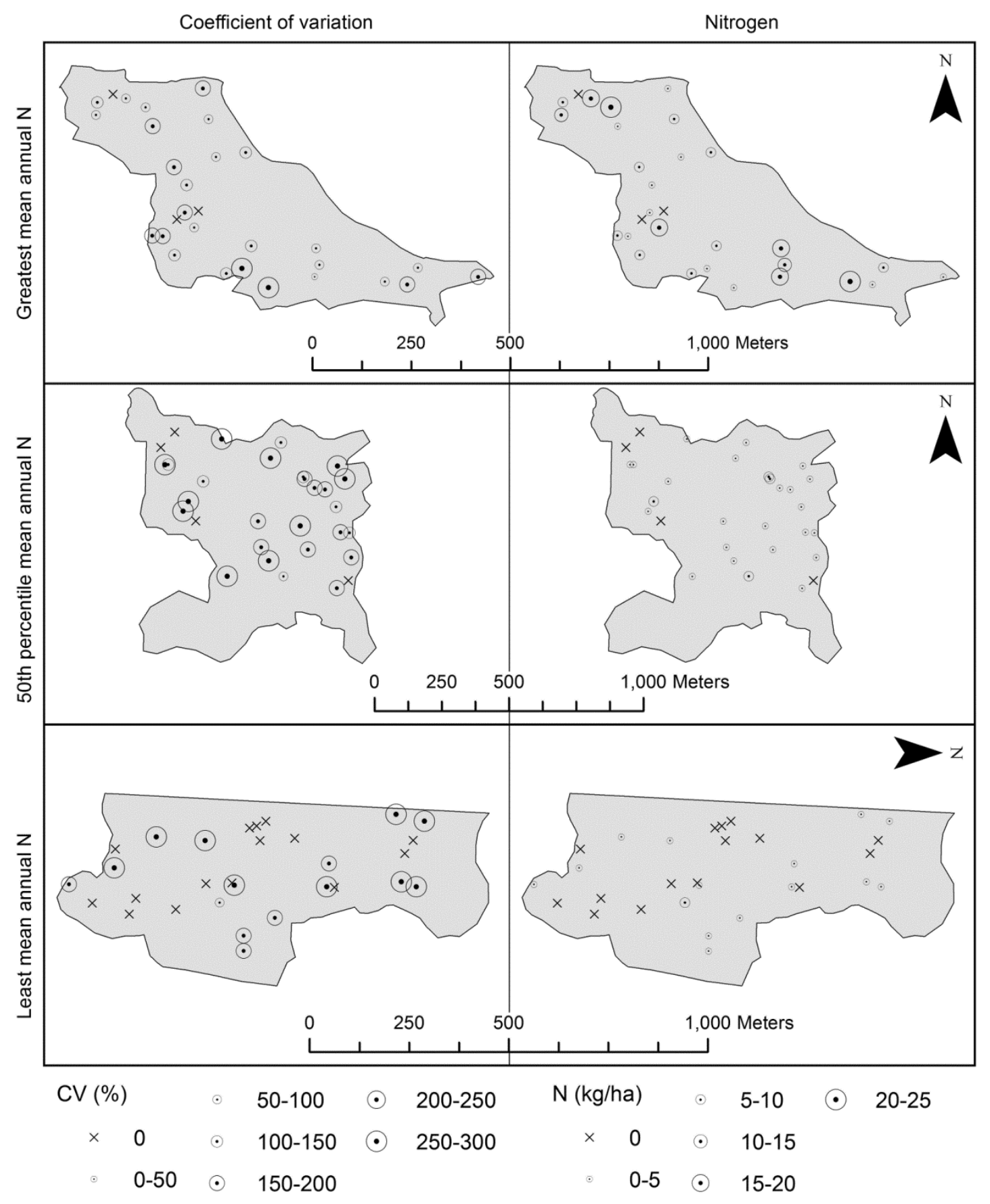


Figure 3.4: (page 50) Maps of three eastern hemlock (Tsuga canadensis) stands depicting the coefficient of variation of white-tailed deer (Odocoileus virginianus) fecal pellet group counts $(C V=100 \cdot($ standard deviation/mean) over the eight-year study at the plot level (left panel) and mean annual plot-level deer-excreted $\mathrm{N}$ (right panel). The stands displayed, from top to bottom, are those of greatest mean annual deer use, intermediate deer use, and lowest deer use among the persistent deeryards group. On the left, smaller circles represent consistent deer use at the plot level, larger circles represent more variable deer use over time, and an "X" denotes a plot where no pellet groups have been observed. 


\section{Interactions of forage preference and foliar chemistry: implications for forest structure and composition ${ }^{3}$}

\subsection{Abstract}

Browsing ungulates can alter the structure and composition of forests through selective foraging. However, the strength of herbivore impacts may vary greatly at the landscape scale according to abiotic resource availability. In Isle Royale National Park, Michigan, USA, moose (Alces alces) inhabit a range of habitat types from southern boreal to northern hardwood forest. Landscape-level patterns in forage quality and availability appear to be driven by soil conditions that are related to glacial history. We examined the hypothesis that the impact of browsing mammals on winter forage varies spatially at landscape scales according to spatial patterns in abiotic resource availability that affect the palatability of food sources. Ninety balsam fir (Abies balsamea) saplings (0.5-3.0 m height) were destructively sampled from 30 boreal forest sites located on Isle Royale. For each sapling, we determined the dry mass of foliage, branch, and stem tissues, estimated minimum age by counting annual growth rings, and analyzed foliar tissue for $\mathrm{C}, \mathrm{N}$, and ${ }^{13} \mathrm{C}$ composition on a mass basis. Forest structure and composition, as well as the density of understory vegetation, was also measured at each site. Moose browsing impacts on fir sapling allometry corresponded with the gradient in soil type. Saplings growing on deeper soils were older and contained less foliage compared to saplings of similar diameter growing in shallower, deglaciated soils. Foliar chemistry also varied along the soil depth gradient, with saplings on deeper soil exhibiting lower tissue $\mathrm{C}: \mathrm{N}$ and greater in $\Delta$ (discrimination against $\left.\delta^{13} \mathrm{C}\right)$. Saplings growing in forests of greater overstory basal area and stem density were also lower in $\mathrm{C}: \mathrm{N}$ and greater in $\Delta$. The $\Delta$ values increased with sapling minimum age, while $\mathrm{C}: \mathrm{N}$ did not vary according to age. The density of understory vegetation was unrelated to foliar $\mathrm{C}: \mathrm{N}$ and $\Delta$. Fir saplings growing in deeper soils tended to be more photosynthetically active (greater $\Delta$ ), but were more likely to be browsed by moose due to their higher forage quality (lower C:N). The

\footnotetext{
${ }^{3}$ This chapter is in preparation for submission to the peer-reviewed journal Oecologia. Authors include B. D. Murray, C. R. Webster, J. A. Vucetich, J. K. Bump, and E. A. Lilleskov.
} 
presence of moose browsing makes fir saplings more likely to reproduce and recruit into the canopy on poorer sites. Consequently, balsam fir is a greater component of the overstory on these sites.

\subsection{Introduction}

The ecological impacts of browsing ungulates are of concern to a broad range of natural resource interest groups (Côté et al. 2004). Browser impacts include leaf and shoot cropping of woody plants, browsing herbaceous vegetation, direct and indirect effects on nutrient availability, and soil compaction via trampling (Persson et al. 2000; Rooney and Waller 2003; Hobbs et al. 2006). These impacts function as disturbances within forest ecosystems, but they can lead to undesirable ecosystem change when browsers increase in density or are introduced to a new location (Ripple et al. 2010). In these settings browsing mammals can function as a perturbation, initiating a positive feedback which shifts the forest plant community to an alternate state (Stromayer and Warren 1997; Côté et al. 2004).

Although focus is often placed on the impacts of the browser, characteristics of the system will also influence the outcome of the interaction (Schmitz et al. 1997). According to optimal foraging theory, browsers select food sources that allow them to maintain a positive energy balance (Schoener 1971; Moen et al. 1997). Browsers choose to forage on some species more than others due to variation in palatability, and preferred species can vary over time and space with browser abundance and plant community composition (Pastor and Naiman 1992). For example, in riparian habitats moose (Alces alces) prefer to browse willow (Salix sp.) shoots because of their palatability (Butler and Kielland 2008). In upland areas moose will select birch (Betula sp.) and aspen (Populus sp.) shoots, but may browse conifers such as fir (Abies sp.) and pine (Pinus sp.), in order of decreasing palatability. Spruces (Picea sp.) have highly lignified and defended shoots, so that they are much less preferred (Peek et al. 1976; Belovsky 1981).

Leaf and shoot chemistry, and therefore palatability, can vary within individuals

of the same species growing under different environmental conditions. Plant species exist within a range of environmental conditions that supply the appropriate amount of 
resources for their growth and survival (Whittaker 1956). Within this range, the chemistry of plant tissues can vary enough to make them more or less preferred by herbivores (Burney and Jacobs 2011). Fertilization of Pacific Northwest conifers (Burney and Jacobs 2011) and northern hardwood forest tree species (Tripler et al. 2002) can increase foliar nitrogen, making these trees more preferred by cervids. Nitrogen tends to be a limiting element in boreal forests (Bryant et al. 1983), so that changes in soil nitrogen availability or a plant's ability to take it up may alter foliar C:N.

We hypothesized that the impact of browsing mammals on winter forage varies spatially at landscape scales according to spatial patterns in abiotic resource availability that affect the palatability of food sources. We used the moose (Alces alces) population of Isle Royale National Park, Michigan, USA, as a study system. The nutrient content and rooting depth of soils on Isle Royale vary along an east-west gradient due to the glacial history of the region (Huber 1973). As the most recent continental glacier in North America retreated, it paused briefly in the middle of what later became Isle Royale. Glacial debris was deposited on the west side of the main island, whereas the east side was scoured as the glacier retreated rapidly over this area (Huber 1973). Moose arrived on the island circa 1910 and have greatly affected the structure and composition of Isle Royale's boreal forests (Snyder and Janke 1976). However, these impacts are not uniform across the island. Specifically, moose likely reduced the abundance of balsam fir (Abies balsamea), a moderately preferred winter forage plant, to a greater extent in areas of deeper, glacial-source soils. To test our hypothesis, we examined the tissue allometry (a cumulative measure of browse impact on growth form), leaf carbon and nitrogen composition (a measure of palatability), and photosynthetic discrimination $(\Delta)$ against ${ }^{13} \mathrm{C}$ (the heavy $\mathrm{C}$ stable isotope) of balsam fir saplings grown on different soil types. We expected fir saplings growing in deeper, glacial-source soils to be more impacted by moose browsing due to higher leaf nitrogen content compared to carbon content. We expected to find the opposite for saplings growing in deglaciated soils. This hypothesis represents a test of the general question: does landscape level spatial heterogeneity in abiotic resource availability drive spatial patterns in browser impacts on forest structure and composition? 


\subsection{Methods}

\subsubsection{Site description}

Isle Royale National Park, Michigan, USA, is a $544 \mathrm{~km}^{2}$ island in Lake Superior that is approximately $20 \mathrm{~km}$ from mainland Ontario. The main island consists of a series of long ridges with a northeast-to-southwest orientation. The spatial distribution of forest types on Isle Royale is strongly influenced by Lake Superior. East side forests are dominated by boreal forest trees such as balsam fir, white spruce (Picea glauca), black spruce (Picea mariana), quaking aspen (Populus tremuloides), and paper birch (Betula papyrifera). West side boreal forest habitats are located along the lakeshore, while inland forests are composed of species more indicative of northern hardwood forests, such as sugar maple (Acer saccharum), northern red oak (Quercus rubra), and yellow birch (Betula alleghaniensis). The structure and composition of Isle Royale's boreal forests vary considerably from the east to the west ends of the island. The east side tends to contain dense boreal conifer forests of lower basal area and higher stem density, whereas western forests contain larger trees at lower densities (Table 4.1). The size structure of east-side balsam fir suggests that sapling recruitment is common over a large area. On the west side, balsam fir size structure is divided between small saplings ( $<2 \mathrm{~m}$ tall) and large trees $(>25 \mathrm{~cm}$ diameter at breast height $(\mathrm{DBH} ; 1.37 \mathrm{~m}))$, suggesting that widespread recruitment has occurred infrequently in recent decades.

\subsubsection{Sampling methods}

Study site locations were chosen randomly within boreal forest habitat types. Fifteen sites were placed on each side of Isle Royale for a grand total of 30 sites. First, the study area was divided into 1x1 km grid cells, and cells were selected for sampling using a random number generator ( $\mathrm{R} 2009$ ). The specific sampling location within each cell was identified by generating a random point using R. Site locations were constrained to be greater than $2 \mathrm{~km}$ from another site and located within a boreal forest habitat type. Before field work began, two sites on the west side were placed randomly in locations of interest that random sampling failed to capture. These locations included Beaver Island because it resembles the east side in forest attributes, and the Washington Creek Gauging 
Station because of its high density of balsam fir saplings. Sites were required to contain at least three balsam fir saplings greater than $0.5 \mathrm{~m}$ in height, or a replacement site was chosen. This occurred at three sites on the west side.

Ten sampling stations were established at $10 \mathrm{~m}$ intervals along a $100 \mathrm{~m}$ transect which paralleled the long axis of the island $\left(60^{\circ} \mathrm{NE}\right.$ and $\left.240^{\circ} \mathrm{SW}\right)$. Detailed forest measurements were taken at stations $1,3,5,7$, and 9. Overstory trees were inventoried using a variable radius plot with $10-\mathrm{ft}^{2} \mathrm{ac}^{-1}$ basal area factor (Avery and Burkhart 2002). The species and DBH were recorded for each live and dead standing tree in the plot so that site-level basal area $\left(\mathrm{m}^{2} \mathrm{ha}^{-1}\right)$ and stem density $\left(\right.$ trees $\left.\mathrm{ha}^{-1}\right)$ could be computed for each species

Three balsam fir saplings (0.5-3.0 $\mathrm{m})$ were collected from each Isle Royale site, for a grand total of 90 saplings. One sapling from each of three height classes (0.51-1.00 $\mathrm{m}, 1.01-2.00 \mathrm{~m}$, and 2.01-3.00 m) was selected randomly for sampling. If a height class was missing, then a replacement sapling was selected from the next largest class. Each sapling was cut at ground level and collected for both allometric and dendrochronological analysis. The main stem was weighed in the field, cut into $0.5 \mathrm{~m}$ sections, and air-dried prior to storage. All branches and leaves were weighed together in the field and collected in 1-gal polyurethane bags. For the larger saplings, branches and leaves were subsampled evenly from the top, middle, and bottom portions of the stem. At least $20 \%$ of the total weight was collected. To assess environmental conditions at the site of each sapling, the overstory was sampled using a $10-\mathrm{ft}^{2} \mathrm{ac}^{-1} \mathrm{BAF}$ variable radius plot while the density of understory plant competitors (stems $<3.0 \mathrm{~m}$ height) was measured within a $10 \mathrm{~m}^{2}$ circular plot centered on the sapling.

Increment cores were collected from seven dominant or subdominant canopy trees including three balsam fir, three white spruce, and one stand history tree at each site. Sampling of the trees occurred by randomly selecting one balsam fir tree in each of three DBH classes: $10-15 \mathrm{~cm}, 15-20 \mathrm{~cm}$, and $>20 \mathrm{~cm}$. The nearest white spruce tree within the same DBH class was also cored. Two cores were collected from each tree at a height of $0.25 \mathrm{~m}$ from the base of the tree. This height generally corresponds with the height at which a stem becomes vulnerable to moose browsing. If the bole was unsuitable for coring at that height, then the cores were taken at $1.37 \mathrm{~m}$ height. The stand history cores 
were collected from the largest (in DBH) overstory tree that was not hollow, and they were taken at $1.37 \mathrm{~m}$ height.

\subsubsection{Balsam fir allometry and leaf composition}

In the laboratory, the total dry mass of each sapling component (stem, branches, and leaves) was measured after drying at $60^{\circ} \mathrm{C}$ for 48 hours (or constant weight). Leaf tissues were subsequently ground and homogenized in a coffee grinder and analyzed for $\mathrm{C}(\%), \mathrm{N}(\%), \delta^{13} \mathrm{C}(\%)$, and $\delta^{15} \mathrm{~N}(\%)$ content on a mass basis. Elemental and isotopic analyses were conducted using a ThermoFinnigan Delta ${ }^{\text {plus }}$ Continuous-Flow Mass Spectrometer.

\subsubsection{Dendrochronology}

A $2-5 \mathrm{~cm}$ thick disc was cut from each sapling stem at the base, $0.25 \mathrm{~m}$ height, $0.50 \mathrm{~m}$ height, and then every $0.50 \mathrm{~m}$ thereafter. The surface of each disc was sanded before measuring the increment growth rings on a binocular microscope and stage micrometer with a linear encoder (Stokes and Smiley 1996, Speer 2010). Tree cores were mounted, sanded, and measured in the same manner. Attempts to cross-date sapling stem discs with overstory trees were unsuccessful because they did not meet the minimum recommended cross-correlation (Speer 2010). This is a common problem for saplings growing in the understory exposed to variable light conditions and browsing (Lorimer et al. 1999).

\subsubsection{Statistical analysis}

The long-term impacts of moose browsing on balsam fir saplings were assessed using whole-tree allometric and dendrochronological methods. These techniques were chosen rather than more direct methods (e.g. counting browsed shoots) because many fir saplings established several decades ago, and our goal was to integrate the impact of browsing over the lifetime of a sapling. We developed linear allometric equations relating stem diameter ( $0.25 \mathrm{~m}$ height) to leaf and aboveground shoot (sum of branches and main stem) mass individually. Leaf mass and shoot mass were log transformed to meet the 
normality assumption of linear regression. One and three statistical outliers were removed from the leaf mass and shoot mass equations, respectively, so that the residuals of the linear regression would be normally distributed. However, their removal did not alter the outcome of the analyses.

Next, we tested the expectation that leaf elemental content and photosynthetic capacity would vary according to soil type using one-tailed $t$-tests. One-tailed tests were appropriate because we hypothesized that $\mathrm{N}$ and $\Delta$ would be greater for saplings growing in deeper soils, while $\mathrm{C}: \mathrm{N}$ would be greater in shallower soils. To determine if $\mathrm{C}: \mathrm{N}, \mathrm{N}$, and $\Delta$ were influenced by other environmental factors we conducted a backward stepwise linear regression procedure using the "stepAIC" function in the R (R 2012) package MASS (Venables and Ripley 2002). The predictor variables in the starting model for C:N and $\mathrm{N}$ included minimum age (square root-transformed), overstory index ((relative basal area + relative stem density)/2; relative to maximum; square root-transformed), competitor density (log-transformed), and a categorical variable for soil type (deep and scoured). The starting model for $\Delta$ included $\mathrm{N}$ in addition to these variables.

We assessed the effect of forage quality $(\mathrm{C}: \mathrm{N})$ and photosynthetic capacity $(\Delta)$ on the impact of moose browsing on sapling allometry (leaf mass:stem diameter) using linear regression equations. We tested whether the intercepts and slopes of each regression model differed by the soil categorical variable.

\subsection{Results}

Balsam fir saplings growing in deeper soils, common on the west side of Isle Royale, exhibited considerable signs of chronic moose browsing through allometry and dendrochronology compared to those growing in shallower soils on the east side (Fig. 4.1). Sapling height and minimum age were significantly related $\left(R^{2}=0.32 ; N=90 ; P<\right.$ $0.001)$ and saplings of similar age growing in deeper soils were shorter in height $(t=$ 2.27; $d f=87 ; P=0.026$ ) (Fig. 4.1A). Leaf mass increased with stem diameter in both soil types $\left(R^{2}=0.65 ; N=88 ; P<0.001\right)$, although saplings growing in deeper soils had less leaf mass at a given diameter $(t=3.01 ; d f=86 ; P=0.003)$ (Fig. 4.1B). Aboveground shoot mass also increased with stem diameter $\left(R^{2}=0.90 ; N=86 ; P<0.001\right)$, and deep 
soil saplings were composed of more shoot mass than shallow soil saplings of similar diameter $(t=3.33 ; d f=88 ; P<0.001)$ (Fig. 4.1C). Taken together, these results confirm quantitatively that fir saplings growing in deeper soil were browsed more intensely than those growing in shallower soils (Fig. 4.2).

$\mathrm{C}: \mathrm{N}$ and $\mathrm{N}$ content, general indicators of browse quality, suggested that fir saplings growing in deeper soil are likely to be more preferred by moose compared to those growing in shallower soils. $\mathrm{C}: \mathrm{N}$ was significantly lower and $\mathrm{N}$ significantly greater in deeper soil types (Table 4.2). Although this measure of $\mathrm{C}: \mathrm{N}$ represents the mean of all leaves from a sapling other than current year's growth, the current year's growth of fir saplings, collected during winter, varies in the same manner (J.A. Vucetich, unpublished data). Leaf $\mathrm{N}$ content was not influenced by overstory conditions, age, or competitor density, while the intercept varied by soil type (Table 4.3). Leaf C:N decreased with increasing overstory index and was significantly greater in scoured-soil sites (Table 4.3; Table 4.4).

Discrimination against ${ }^{13} \mathrm{C}(\Delta)$ was significantly greater for deep-soil saplings (Table 4.2), suggesting lower water use efficiency. The best linear regression model for $\Delta$ included overstory, $\mathrm{N}$, and minimum age (Table 4.3). $\Delta$ increased with the overstory index and $\mathrm{N}$ content, and decreased with minimum tree age at the time of sampling (Table 4.5). Although the soil type parameter was not included in the final model, $\Delta$ was significantly greater for deep-soil saplings (Table 4.2). This discrepancy occurred because $\mathrm{N}$, which also varied according to soil type, was included in the regression model.

Leaf $\mathrm{C}: \mathrm{N}$ and $\Delta$ were significantly related to the leaf mass:stem diameter ratio (a measure of browse impact) in a manner consistent with foraging theory. Fir saplings that were greater in $\mathrm{N}$ relative to $\mathrm{C}$ (lower $\mathrm{C}: \mathrm{N}$ ) contained less leaf mass per stem diameter compared to saplings of greater C:N (Fig. 4.3A). Fir saplings with greater photosynthetic capacity (greater $\Delta$ ) also exhibited a lower leaf mass:stem diameter than those of lower $\Delta$ (Fig. 4.3B). 


\subsection{Discussion}

The current state of Isle Royale's boreal forests represents two divergent ecosystem states that include the same browser and similar plant communities. Balsam fir saplings that are greater in foliar $\mathrm{N}$ content are chronically suppressed by browsing, but they are able to survive for decades. They are more photosynthetically active on a leaf mass basis although they contain less overall leaf mass at a given size. However, chronic browsing will inhibit them from reaching a mature height and reproducing.

Previous studies from Isle Royale and elsewhere have reported that moose browsing hastens succession in boreal forests. Aspens, birches, and willows are fastgrowing, shade-intolerant deciduous trees that establish following disturbance. The rate at which these forests transition to late-successional, shade-tolerant conifers such as spruce is increased if moose browsing is intense (Frelich 2002; Butler and Kielland 2008). Balsam fir holds an interesting, intermediate position within the successional sequence as being a mid-successional, shade-tolerant conifer that is preferred by moose as winter forage (Bergerud and Manuel 1968; Belovsky 1981). After the arrival of moose on Isle Royale circa 1910, fir abundance declined considerably in response to browsing (Snyder and Janke 1976). Our results suggest that fir continues to persist, but not necessarily thrive, under two contrasting scenarios with differing life-history strategies.

First, on sites with deeper, glacial-origin soils, fir saplings are often selected for foraging by moose due in part to lower $\mathrm{C}: \mathrm{N}$ of foliar tissues. Growth suppression due to moose browsing is intense (e.g. Fig. 4.1; Fig. 4.2). Lower foliar $\mathrm{C}: \mathrm{N}$ is likely to be the combined result of greater soil $\mathrm{N}$ availability in glacial-origin soils as well as greater overstory cover. Balsam fir saplings growing in shaded environments produce leaves lower in C:N (Richardson 2004). In shrub tundra habitats of Denali National Park, Alaska, moose preferred to forage on the more nutritious shade leaves of willow, rather than sun leaves (Molvar et al. 1993). Among deciduous species, ungulate browsing can increase leaf tissue $\mathrm{N}$ content as the tree attempts to compensate for herbivory (Scogings et al. 2011). However, compensatory growth is not a common response of conifers to herbivory (Bryant et al. 1983; Danell et al. 1991; Edenius et al. 1993), suggesting that this is an unlikely response from fir saplings. This ecosystem state is unlikely to provide 
increased energy or nutrition to moose. Although fir tissues are higher in $\mathrm{N}$ content, there is less biomass available for browsing (McLaren 1996).

The second ecosystem state is driven by shallower, glacially-scoured soils of generally lower nutrient availability and lower rooting depth, which characterize the east side of the main island and many outlying smaller islands (Huber 1973). Available balsam fir forage is higher in $\mathrm{C}: \mathrm{N}$ and generally less nutritious and palatable to moose. Boreal forest canopies are more open, and fir saplings growing in sun tend be higher in C:N (Richardson 2004). McLaren (1996) also reported that fir saplings on the east side were less suppressed from browsing than those in the west. East side saplings were also more likely to die from simulated moose browsing compared to west side saplings, especially those growing in shade (McLaren 1996). Despite being rooted in poorer soils, these saplings grow faster than those rooted in richer soils (Fig. 4.1A), but with greater browsing pressure.

Our results represent a link between optimal foraging theory and landscape-level heterogeneity in abiotic resources. Foraging ungulates should select foraging patches and spend an appropriate amount of time in them to maintain a positive energy balance (Schoener 1971; Moen et al. 1997). Intuitively, this would suggest that ungulates would congregate in foraging patches that are more productive from the bottom up. With respect to balsam fir, a preferred winter forage (Belovsky 1981), moose on Isle Royale face an optimal foraging conundrum. A moose foraging on more nutritious fir saplings will find less to eat overall, whereas a moose foraging where there is plenty of fir would be eating lower quality food. This conundrum has implications for feedbacks between ungulate populations, forage availability, and habitat sustainability. We acknowledge that our inference is limited to one species, balsam fir, and that other moose forage species vary in abundance across Isle Royale. Future studies could build on this work by building a multi-species conceptual model.

Concentrations of chemical defenses, such as plant secondary metabolites, can vary within species and may be a future factor to consider. Plant secondary metabolites decrease a plant's desirability to herbivores, but have no physiological purpose. They incur a production cost, and some studies have suggested that individuals with more resource availability are more able to defend themselves against herbivory (Coley et al. 
1985). The winter forage intake rate of moose and other boreal forest herbivores may be limited by the amounts of secondary metabolites that they are able to detoxify, as suggested by the detoxification limitation hypothesis (Sauvé and Côté 2006; Marsh et al. 2006).

From an evolutionary perspective, it is advantageous to be a sapling growing on a poorer site where the risk of browsing is less. Although growth might occur at a slower rate, they are more likely to reach reproductive maturity. On nutrient-rich sites, saplings likely have a greater potential growth rate, but they fail to realize it due to their preference by browsers as a forage item. They may survive in a pollarded state for decades, but they will fail to reproduce unless they grow beyond the reach of browsers. The paucity of overstory-size fir trees (Table 4.1) and fir saplings $>2.0 \mathrm{~m}$ tall on nutrientrich sites compared to nutrient-poor sites provides preliminary support for this hypothesis.

In conclusion, the impacts of browsing ungulates may exaggerate differences in forest structure and composition due to spatial heterogeneity in resource availability. Selective herbivory by ungulates affects plant community composition and ecosystem processes (Augustine and McNaughton 1998). Our study demonstrates how a single species can vary in tissue quality according to a spatial gradient in resource availability, which was ultimately set in place by an idiosyncrasy of glacial history. 


\subsection{Tables and Figures}

Table 4.1: The structure and composition of boreal forests in Isle Royale National Park, Michigan USA, varies from the east to the west sides of the main island. This pattern corresponds with the soil types found in each location, with deeper glacial-origin soils located in the west and shallower, glacially-scoured soils in the east. Boreal forests located in deep-soil areas were greater in basal area and lower in stem density compared to those located on glacially scoured soils. Data were obtained by sampling 30 sites on Isle Royale: 13 in deep soil types and 17 in shallow soil types (Fig. 4.2).

\begin{tabular}{lcccc}
\hline \multirow{2}{*}{\multicolumn{1}{c}{ Species }} & \multicolumn{2}{c}{ Basal area $\left(\mathrm{m}^{2} \cdot \mathrm{ha}^{-1}\right)$} & \multicolumn{2}{c}{ Stem density $\left(\mathrm{stems}^{-1} \mathrm{ha}^{-1}\right)$} \\
\cline { 2 - 5 } & Deep & Scoured & Deep & Scoured \\
\hline Abies balsamea & $0.92(0.22)$ & $1.81(0.51)$ & $12.0(3.0)$ & $121.8(40.8)$ \\
Acer saccharum & $1.06(0.81)$ & - & $20.1(16.5)$ & - \\
Betula alleghaniensis & $3.53(1.65)$ & $0.14(0.14)$ & $30.6(11.3)$ & $0.5(0.5)$ \\
Betula papyrifera & $4.17(0.92)$ & $4.24(0.84)$ & $52.3(16.2)$ & $81.0(20.1)$ \\
Fraxinus nigra & $0.04(0.04)$ & - & $1.6(1.7)$ & - \\
Picea glauca & $5.62(1.01)$ & $3.62(0.73)$ & $123.2(28.1)$ & $90.5(22.4)$ \\
Picea mariana & $0.25(0.16)$ & $1.11(0.53)$ & $7.5(5.7)$ & $45.1(24.3)$ \\
Pinus resinosa & - & $0.05(0.06)$ & - & $0.7(0.7)$ \\
Pinus strobus & $0.11(0.11)$ & $0.22(0.14)$ & $0.2(0.2)$ & $0.8(0.5)$ \\
Populus tremuloides & $2.19(1.37)$ & $4.29(1.09)$ & $17.6(12.3)$ & $47.1(13.7)$ \\
Thuja occidentalis & $3.81(1.07)$ & $0.54(0.26)$ & $48.1(14.8)$ & $10.8(5.0)$ \\
\hline
\end{tabular}


Table 4.2: Results of one-tailed $t$-tests of the hypothesis that each leaf tissue variable is significantly greater $(\mathrm{N}$ and $\Delta)$ or less $(\mathrm{C}: \mathrm{N})$ for balsam fir (Abies balsamea) saplings collected from deep-soil sites in Isle Royale National Park, Michigan, USA.

\begin{tabular}{lccc}
\hline & \multicolumn{2}{c}{ Soil type $^{\mathrm{b}}$} & \multirow{2}{*}{$P$} \\
\cline { 2 - 3 } Variable $^{\mathrm{a}}$ & Deep & Scoured & \\
\hline $\mathrm{C}: \mathrm{N}$ & $39.00(1.21)$ & $51.02(1.26)$ & $<0.001$ \\
$\mathrm{~N}(\%)$ & $1.32(0.04)$ & $1.01(0.03)$ & $<0.001$ \\
$\Delta(\%)$ & $24.1(0.2)$ & $23.1(0.2)$ & $<0.001$
\end{tabular}

$\overline{{ }^{a}}$ Sample size $N=89$ saplings (Deep $n=39$; Scoured $n=50$ ) for each variable; one leaf tissue sample was lost.

${ }^{\mathrm{b}}$ Mean (standard error). 
Table 4.3: Model selection results for C:N, N (\%), and $\Delta(\%)$. "Soil" is a categorical variable for soil type (deep; scoured). "Overstory" is an importance value ((relative basal area + relative stem density) 2 ; relative to maximum value) that represents an index of overstory cover, with a greater value suggesting greater cover and less understory light availability. The "Competitors" variable is the density of vegetation (0.25-3.00 m height) within $1.78 \mathrm{~m}$ of the fir sapling $\left(10 \mathrm{~m}^{2}\right.$ circular plot). "Age" represents the minimum age of the fir sapling, measured by counting growth increment rings at a height of $0.25 \mathrm{~m}$. " $\mathrm{N}$ " is the $\mathrm{N}$ content (\% on a mass basis) of the fir sapling's leaf tissues. Overstory and Age values were square root-transformed, and competitor densities were log-transformed to satisfy linear modeling assumptions.

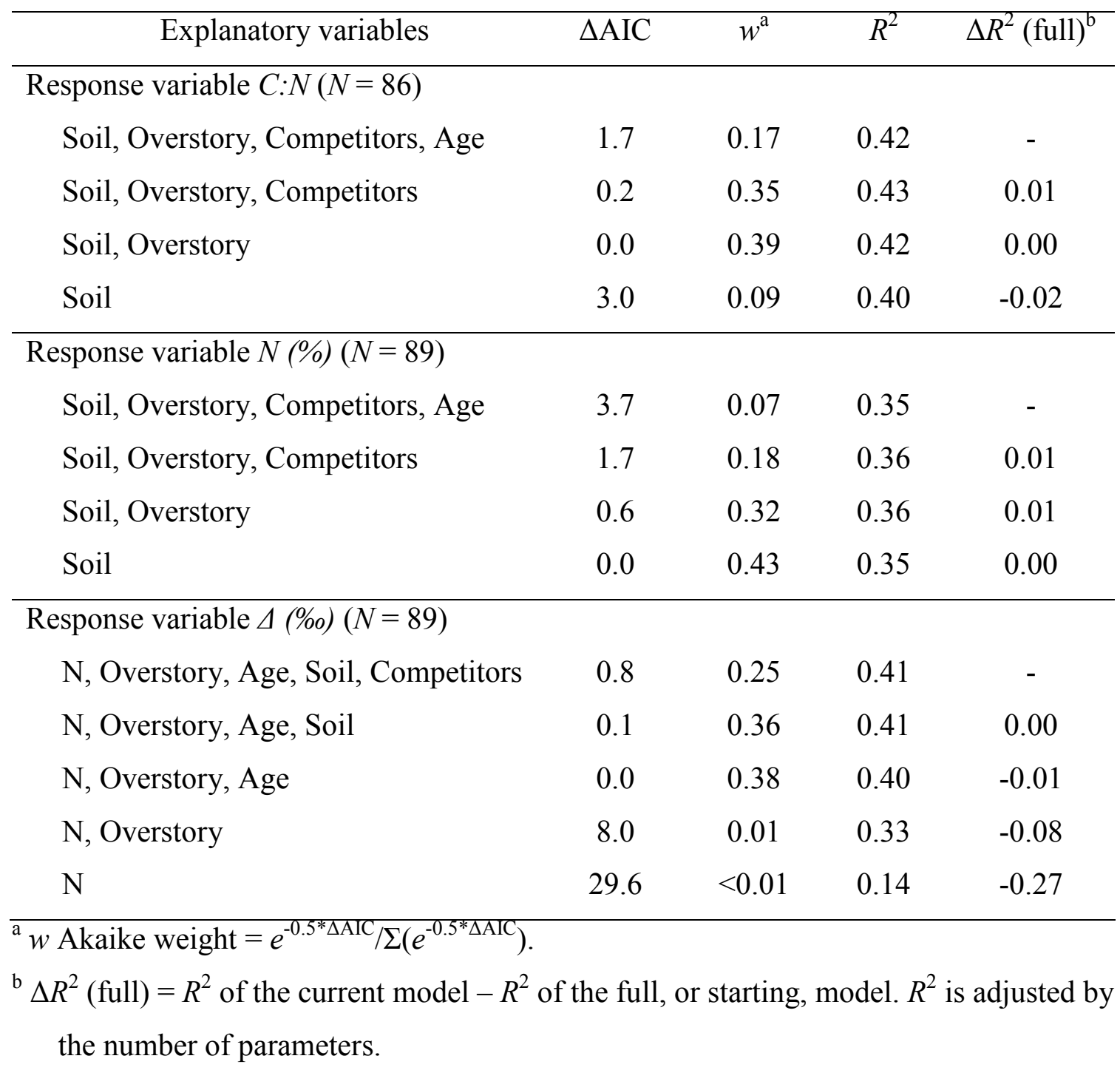


Table 4.4: Parameter estimates for the most parsimonious (lowest AIC within 2 units; fewest parameters) model of $\mathrm{C}: \mathrm{N}\left(R^{2}=0.42 ; P<0.001\right)$. "Overstory" is an importance value ((relative basal area + relative stem density) $/ 2$; relative to maximum value) that represents an index of overstory cover, with a greater value suggesting greater cover and less understory light availability.

\begin{tabular}{lccc}
\hline Variable $^{\mathrm{a}}$ & Parameter estimate $^{\mathrm{b}}$ & $t$ & $P$ \\
\hline Soil & $11.73(1.53)$ & 7.66 & $<0.001$ \\
Overstory $^{\mathrm{c}}$ & $-1.08(0.48)$ & 3.61 & $<0.001$ \\
\hline
\end{tabular}

${ }^{a}$ Sample size $N=86$ saplings and associated data; three outliers were removed to satisfy the assumption of linear regression that $\varepsilon \sim N(0, \sigma)$; one leaf tissue sample was lost.

${ }^{\mathrm{b}}$ Standard error in parentheses.

${ }^{\mathrm{c}}$ Square root-transformed. 
Table 4.5: Parameter estimates for the most parsimonious (lowest AIC within 2 units; fewest parameters) model of $\Delta\left(R^{2}=0.40 ; P<0.001\right)$. "Soil" is a categorical variable for soil type (deep; scoured). "Overstory” is an importance value ((relative basal area + relative stem density)/2; relative to maximum value) that represents an index of overstory cover, with a greater value suggesting greater cover and less understory light availability. " $\mathrm{N}$ " is the $\mathrm{N}$ content (\% on a mass basis) of the fir sapling's leaf tissues. "Age" represents the minimum age of the fir sapling, measured by counting growth increment rings at a height of $0.25 \mathrm{~m}$.

\begin{tabular}{lccc}
\hline Variable $^{\mathrm{a}}$ & Parameter estimate $^{\mathrm{b}}$ & $t$ & $P$ \\
\hline Overstory $^{\mathrm{c}}$ & $0.39(0.08)$ & 5.10 & $<0.001$ \\
$\mathrm{~N}$ & $1.73(0.48)$ & 3.61 & $<0.001$ \\
Age $^{\mathrm{c}}$ & $-0.30(0.09)$ & -3.26 & $<0.001$
\end{tabular}

${ }^{a}$ Sample size $N=89$ saplings and associated data; one leaf tissue sample was lost.

${ }^{\mathrm{b}}$ Standard error in parentheses.

${ }^{\mathrm{c}}$ Square root-transformed. 

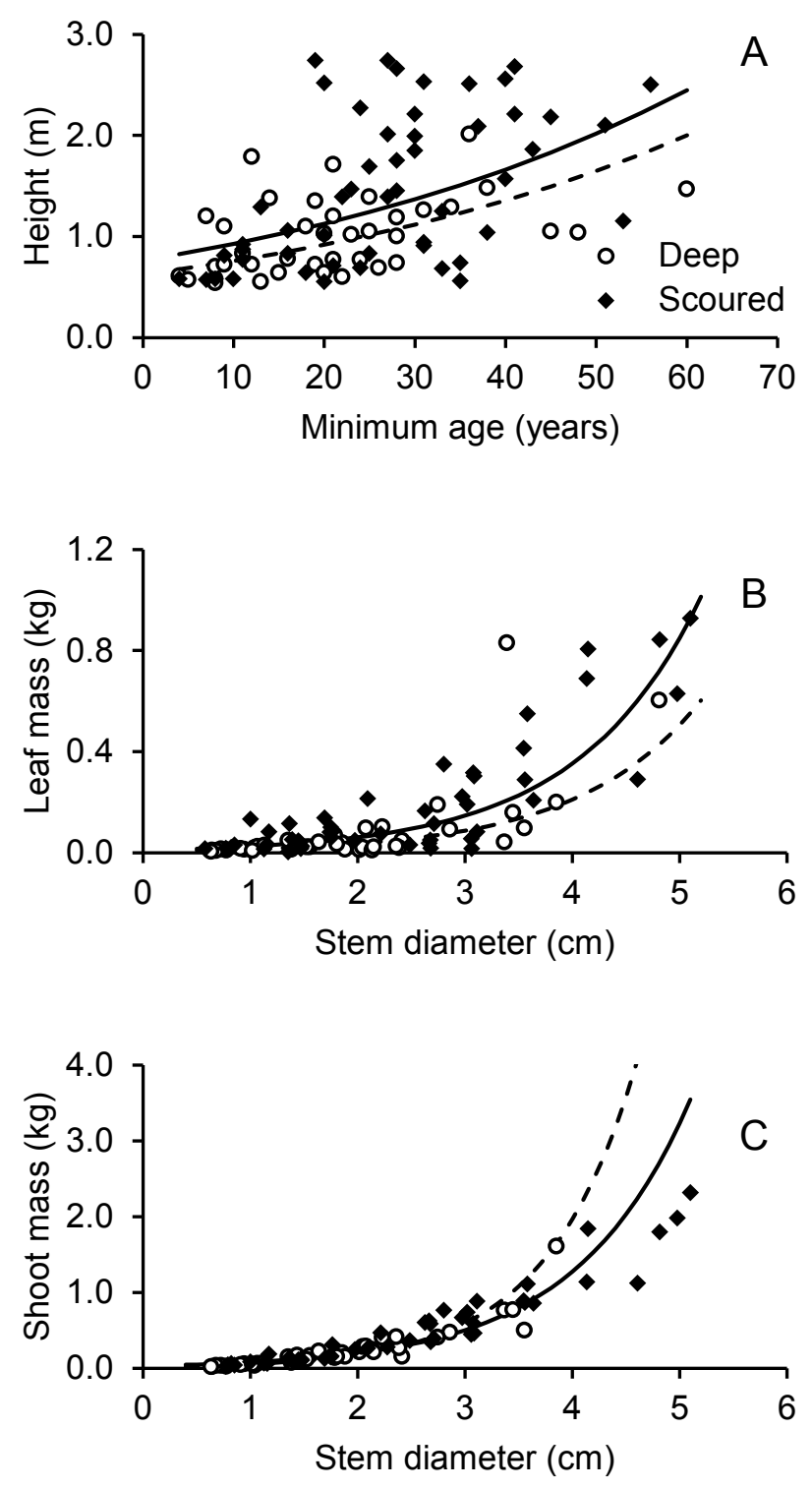
Figure 4.1: (page 68) The impact of moose (Alces alces) browsing on balsam fir (Abies balsamea) saplings differed according to soil type in Isle Royale National Park, Michigan, USA. Linear regression analyses revealed significant relationships between minimum age and height $\left(R^{2}=0.32 ; N=90 ; P<0.001\right)$, stem diameter and leaf mass $\left(R^{2}\right.$ $=0.65 ; N=88 ; P<0.001 ; 1$ outlier removed prior to analysis), and stem diameter and aboveground shoot mass (branches + main stem) $\left(R^{2}=0.90 ; N=86 ; P<0.001 ; 4\right.$ outliers removed prior to analysis). Saplings growing in deeper, glacial-origin soil types tended to be shorter than saplings of similar age and rooted in shallower, glacially-scoured soils $(t$ $=2.27 ; d f=87 ; P=0.026)(a)$. Also, saplings found in deeper soils exhibited less leaf mass than those of similar diameter growing in shallower soils $(t=3.01 ; d f=86 ; P=$ $0.003)(b)$. (Note: in $b$, one outlier (diameter $=8.2 \mathrm{~cm}$; leaf mass $=2.32 \mathrm{~kg}$ ) was excluded from the figure and linear regression). In $(c)$, deep-soil saplings were composed of greater aboveground shoot tissue compared to shallow-soil saplings $(t=3.33 ; d f=88 ; P<$ 0.001). The solid lines represent predicted values for shallow soil sites, and the dashed lines represent predicted values for deep soil sites. 


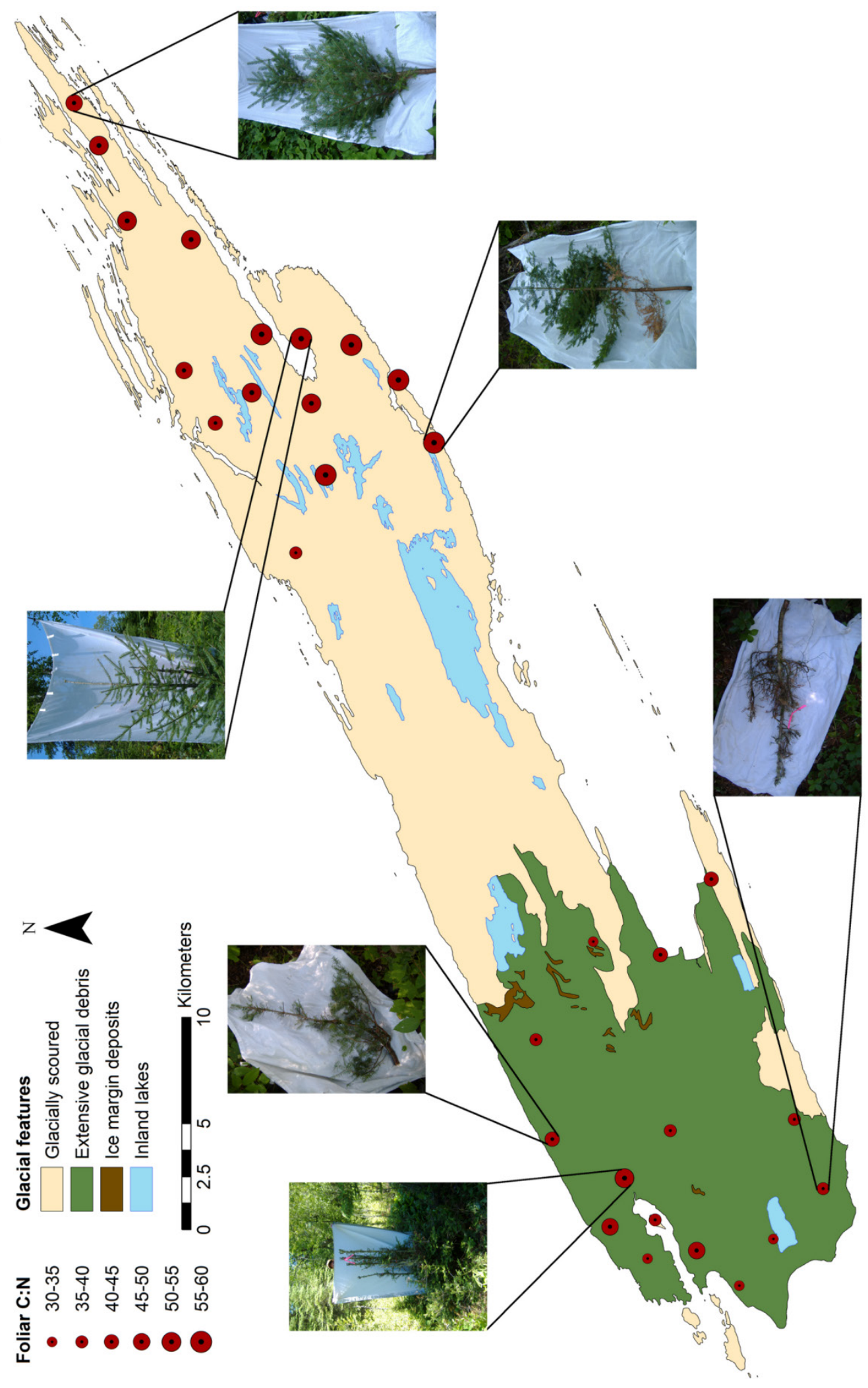


Figure 4.2: (page 70) Balsam fir (Abies balsamea) saplings growing on the west side of Isle Royale National Park, Michigan, USA, showed greater architectural signs of browsing compared to those growing on the east side of the island. Study site locations are represented with red circles, and the size of each circle represents average leaf $\mathrm{C}: \mathrm{N}$ content, measured on a mass basis, at each site. Saplings that were growing in deeper soils of glacial origin had significantly lower $\mathrm{C}: \mathrm{N}$ (more $\mathrm{N}$ relative to $\mathrm{C}$ ) compared to those growing in shallower, glacially-scoured soils. These architectural and chemical differences between saplings growing under different environmental conditions suggest differences in browse preference for moose. Soil data are from Huber 1973. 

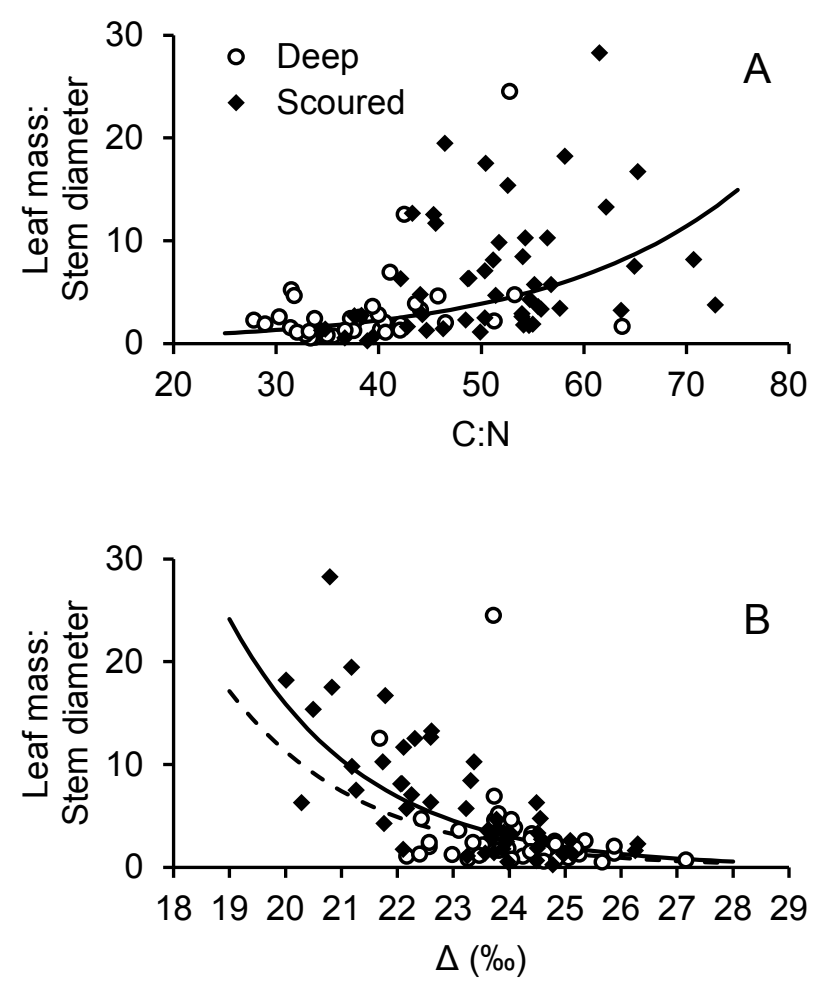

Figure 4.3: The relationship between moose (Alces alces) browsing impact (ratio of leaf mass $(\mathrm{g})$ to stem diameter $(\mathrm{mm})$ ) varied according to foliar chemistry in terms of massbased C:N $\left(R^{2}=0.29 ; N=89 ; P<0.001\right)(a)$ and discrimination against $\delta^{13} \mathrm{C}(\Delta)\left(R^{2}=\right.$ $0.45 ; N=89 ; P<0.001)(b)$ among balsam fir (Abies balsamea) saplings in Isle Royale National Park, Michigan, USA. The relationship between browse impact and C:N did not differ by soil type $(t=0.69 ; d f=87 ; P=0.492)$. For $\Delta$, browse impact was greater (less leaf mass at a given diameter) for saplings growing in deeper soil $(t=2.02 ; d f=87 ; P<$ $0.001)$. In $(b)$, the solid line represents predicted values for shallow soil sites, and the dashed line represents predicted values for deep soil sites. 


\section{Post-disturbance plant community dynamics following a rare natural-origin fire in a Tsuga canadensis forest ${ }^{4}$}

\subsection{Abstract}

Opportunities to directly study infrequent forest disturbance events often lead to valuable information about vegetation dynamics. In mesic temperate forests of North America, stand-replacing crown fire occurs infrequently, with a return interval of 20003000 years. Rare chance events, however, may have profound impacts on the developmental trajectories of forest ecosystems. For example, it has been postulated that stand-replacing fire may have been an important factor in the establishment of eastern hemlock (Tsuga canadensis) stands in the northern Great Lakes region. Nevertheless, experimental evidence linking hemlock regeneration to non-anthropogenic fire is limited. To clarify this potential relationship, we monitored vegetation dynamics following a rare lightning-origin crown fire in a Wisconsin hemlock-hardwood forest. We also studied vegetation in bulldozer-created fire breaks and adjacent undisturbed forest. Our results indicate that hemlock establishment was rare in the burned area but moderately common in the scarified bulldozer lines compared to the reference area. Early-successional, nonarboreal species including Rubus spp., Vaccinium angustifolium, sedges (Carex spp.), grasses, Epilobium ciliatum, and Pteridium aquilinium were the most abundant post-fire species. Collectively, our results suggest that competing vegetation and moisture stress resulting from drought may reduce the efficacy of scarification treatments as well as the usefulness of fire for preparing a suitable seedbed for hemlock. The increasing prevalence of growing-season drought suggests that silvicultural strategies based on historic disturbance regimes may need to be reevaluated for mesic species.

\footnotetext{
${ }^{4}$ This chapter (C) by Murray et al. 2012. Citation: Murray, B. D., S. A. Holmes, C. R. Webster, and J. C. Witt. 2012. Post-disturbance plant community dynamics following a rare natural-origin fire in a Tsuga canadensis forest. PLoS ONE 7:e43867.
} 


\subsection{Introduction}

Infrequent disturbance events can have a profound effect on forest structure and composition (Foster et al. 1998; Frelich 2002; Turner et al. 2003), but they are difficult to study due to their rarity. In mesic temperate forests, fire return intervals can range from several centuries to millennia (Frelich 2002). Much of our understanding of fire ecology and succession in these forests comes from paleoecological and modeling studies (e.g. Frelich et al. 1993; Davis et al. 1998; He and Mladenoff 1999), or the very limited application of prescribed fire (e.g. Pubanz 1996). Opportunities to directly study post-fire regeneration in unmanaged mesic forest are rare.

The disturbance regime of hemlock-hardwood forests ranges from single-treefall canopy gaps (Runkle 1982; Frelich and Lorimer 1991; Frelich and Graumlich 1994) to intermediate-severity windstorms (Stueve et al. 2011). Stand-replacing crown fires are infrequent events, with a return interval of 2000-3000 years (Frelich 2002). However, even age distributions are common in many eastern hemlock (Tsuga canadensis) stands, suggesting a stand-leveling disturbance origin (Maissurow 1941; Hough and Forbes 1943; Foster 1988). This observation has led several researchers to conclude that the episodic nature of hemlock regeneration is due in part to hemlock's response to infrequent fires, although the evidence is largely anecdotal (Maissurow 1941; Miles and Smith 1960; Goff 1967; Eckstein 1980; Simpson et al. 1990). In contrast, Ziegler et al. (2000) reported that burned hemlock forests in Adirondack Park, New York were dominated by deciduous species 90 years after the fire, although the fires occurred in association with logging. The few studies that are available on this topic have typically examined the effects of fire several decades or centuries after the event. Consequently, our understanding of post-catastrophic disturbance vegetation dynamics in this system is limited, especially with regard to the initial interplay between the resurgent plant community, microsite characteristics, and climate. Given changes in regional species pools, legacy effects, and the increasing role of climate change, it is becoming increasingly important to reevaluate these dynamics in contemporary ecosystems, especially for declining "foundation species" (sensu Ellison et al. 2005). 
Ellison et al. (2005) characterize eastern hemlock as a "foundation species" in northern temperate forests of North America. They define a foundation species as "a single species that defines much of the structure of a community by creating locally stable conditions for other species, and by modulating and stabilizing fundamental ecosystem processes" (Dayton 1972; Ellison et al. 2005). In the northern Lake States, the paucity of hemlock regeneration has been a concern to ecologists, foresters, and wildlife managers for several decades (e.g. Graham 1941; Maissurow 1941; Anderson and Loucks 1979; Frelich and Lorimer 1985; Alverson et al. 1988; Mladenoff and Stearns 1993; Rooney et al. 2000; Witt and Webster 2010). Hemlock is important ecologically because it moderates temperature, moisture, and nutrient availability by forming a dense canopy and producing nutrient-poor litter (Ellison et al. 2005). Maintaining hemlock is important to conserving forest biodiversity because of its close association with several bird (Howe and Mossman 1996), terrestrial vertebrate (Wydeven and Hay 1996), and stream-dwelling (Snyder et al. 2002) species. The structural characteristics of hemlock forests create suitable habitat for white-tailed deer (Odocoileus virginianus), birds, mammalian carnivores, and small mammals (Yamasaki et al. 2000). Hemlock was an abundant canopy dominant in the region prior to settlement, but is currently found on less than $0.5 \%$ of its historic range (Mladenoff and Stearns 1993). Demographic models of existing hemlock-hardwood stands in the Lake States predict that hemlock will lose its status as a canopy dominant over the next several centuries (Mladenoff and Stearns 1993; Salk et al. 2011). In the eastern US, hemlock is also threatened by the hemlock woolly adelgid (Adelges tsugae) (Krapfl et al. 2011).

Low rates of hemlock regeneration in the Lake States have been attributed to several interacting factors including climate change, altered disturbance regimes, hemlock life history traits, ecosystem processes, and past land use practices (Mladenoff and Stearns 1993). Other authors have suggested that a regional increase in white-tailed deer densities during the $20^{\text {th }}$ century is limiting hemlock seedling recruitment into larger size classes (Anderson and Loucks 1979; Frelich and Lorimer 1985; Alverson et al. 1988; Rooney et al. 2000). Rooney et al. (2000) demonstrated that seedling establishment was patchy due to local-scale variation in suitable establishment substrates, but that deer browsing is affecting seedling recruitment at the regional scale. Mladenoff and Stearns 
(1993) hypothesized that widespread hemlock recruitment leading to an even-age stand would require an infrequent, catastrophic disturbance followed by several decades of favorably moist climate conditions.

The herbaceous layer (herbaceous and woody plants $<50 \mathrm{~cm}$ height) is an important component of hemlock forests because it functions as a filter for overstory regeneration (George and Bazzaz 2003) and it contains a large proportion of forest biodiversity (Gilliam and Roberts 2003). Following a stand-replacing disturbance, latesuccessional species like hemlock, which are shade-tolerant and slow-growing, are often precluded from establishment by fast-growing herbaceous species capable of responding quickly to increased light availability. Alternatively, a disturbance which does not impact the forest overstory may increase regeneration of late-successional species by reducing herbaceous competition and exposing mineral soil seedbeds (Roberts and Gilliam 2003).

We used a serendipitous experiment where a lightning-origin, stand-replacing crown fire burned a section of hemlock-hardwood forest in north-central Wisconsin. As a result of suppression efforts a large portion of the stand remained unburned. Lines of mechanically scarified soil were created in the unburned area when firefighters used a bulldozer to establish fire breaks. The adjacent burned, scarified, and undisturbed sites created an opportunity to compare understory regeneration response following a disturbance that removed much of the canopy and understory layers (fire), a disturbance where the organic soil and understory vegetation was removed without greatly increasing under-canopy solar radiation (analogous to scarification), and no disturbance. Our first aim was to compare the regeneration response of hemlock-hardwood tree and shrub species among the two disturbance types and the undisturbed area, with an emphasis on eastern hemlock regeneration. Second, we examined patterns in herbaceous-layer regeneration in each disturbed area over the first three years after disturbance, while identifying differences in environmental conditions that are influential to regeneration dynamics. We hypothesized that post-fire conditions would favor ruderal herbaceous and shrub species, whereas post-scarification conditions would facilitate the regeneration of late-successional tree species. 


\subsection{Methods}

\subsubsection{Ethics statement}

All necessary permits were obtained for the described field studies. Specifically, a permit was issued by the Medford/Park Falls Ranger District, Chequamegon-Nicolet National Forest, United Stated Department of Agriculture Forest Service, Park Falls, Wisconsin, USA.

\subsubsection{Study area}

The study area was located in a second-growth hemlock-northern hardwood forest in the Chequamegon National Forest of northwest Wisconsin, USA $\left(45^{\circ} 58^{\prime} \mathrm{N}, 90^{\circ} 00^{\prime} \mathrm{W}\right)$. This area receives average annual precipitation of $77.9 \mathrm{~cm}$ with mean monthly temperature ranging from $-12.2{ }^{\circ} \mathrm{C}$ in January to $20.1{ }^{\circ} \mathrm{C}$ in July (Western Regional Climate Center 2012). The topography of the study area was moderately variable with slopes ranging from $0^{\circ}$ to $16^{\circ}$. Overstory vegetation was primarily composed of eastern hemlock with lesser amounts of red maple (Acer rubrum), sugar maple (Acer saccharum), paper birch (Betula papyrifera), balsam fir (Abies balsamea), yellow birch (Betula alleghaniensis), and hop-hornbeam (Ostrya virginiana). Other overstory species noted in the vicinity of the study area included white pine (Pinus strobus), red pine (Pinus resinosa), northern red oak (Quercus rubra), and northern white-cedar (Thuja occidentalis $)$. The undisturbed sapling layer $(<10 \mathrm{~cm} \mathrm{DBH}$ and $\geq 50 \mathrm{~cm}$ height $)$ consisted of beaked hazel (Corylus cornuta), red maple, eastern hemlock, yellow birch, sugar maple, and balsam fir. The understory layer in the undisturbed area was sparsely vegetated, and characterized by sugar maple seedlings, sedges (Carex spp.), and Dryopteris ferns.

In late May 2006 a lightning strike to a snag initiated a moderate-severity fire at the study site. The fire burned 28 ha of wetlands and mesic northern hardwood forest, including 4 ha of hemlock-dominated forest (S. Adams and M. Lucas, U.S.D.A. Forest Service, personal communication). A bulldozer was used to create a fire break by clearing vegetation (primarily subcanopy trees and herbaceous vegetation) and organic soil in a line through the forest. Much of the hemlock forest remained unburned. This 
situation allowed us to compare post-disturbance vegetation communities following fire and scarification with those in an undisturbed reference area (Fig. 5.1). The fire was hot enough to kill herbaceous-layer vegetation, saplings, and overstory trees. It affected stand structure, with a lower live basal area in the burned area $\left(10.3 \pm 21.0 ;\right.$ mean $\left.\pm \mathrm{s}^{2}, \mathrm{n}=10\right)$ than in the undisturbed reference area $(45.7 \pm 27.5)$. The bulldozer exposed the mineral soil, displaced coarse woody debris, and removed herbaceous- and sapling-layer vegetation. Basal area in the dozer line plots was intermediate between the fire and undisturbed areas $(30.4 \pm 17.7)$, suggesting that bulldozer operators may have removed some canopy trees and/or avoided dense patches of larger trees. However, the undercanopy light environment was similar in dozer lines and undisturbed plots, whereas it was significantly greater in the burned area (Fig. 5.2). The most recent timber harvest at the study site occurred approximately 30 years ago. Evidence of widespread white-tailed deer herbivory was not observed.

\subsubsection{Field methods}

We used rebar to permanently mark 10 circular plots of $100 \mathrm{~m}^{2}$ area in each of the fire, scarification, and undisturbed areas for a total of 30 plots. Plot locations in the burned and undisturbed areas were selected randomly using ArcView 3.1 Random Point Generator extension (Jenness Enterprises, Flagstaff, AZ, USA) prior to field work. Plots were randomly placed along the center of the dozer line at a minimum of $30 \mathrm{~m}$ separation distance. In each plot we measured the diameter of overstory trees $\geq 10 \mathrm{~cm}$ diameter at breast height (DBH; $1.37 \mathrm{~m})$. To measure sapling density, three $3.14 \mathrm{~m}^{2}$ circular subplots were nested within each $100 \mathrm{~m}^{2}$ plot. In the burned and unburned areas, subplots were placed $3.5 \mathrm{~m}$ from the plot center at azimuths of $0^{\circ}, 120^{\circ}$, and $240^{\circ}$. Dozer line subplots were centered on the dozer line $1 \mathrm{~m}, 3.5 \mathrm{~m}$, and $4.5 \mathrm{~m}$ from the plot center, with the $3.5 \mathrm{~m}$ plot opposite the others. The percent cover of herbaceous-layer species, including woody seedlings, was measured in a $1 \mathrm{~m}^{2}$ quadrant placed within each subplot. We also measured seedling density by species in the $1 \mathrm{~m}^{2}$ quadrants. We defined saplings and seedlings as woody stems $<10 \mathrm{~cm} \mathrm{DBH}$ but $\geq 50 \mathrm{~cm}$ in height, and $<50 \mathrm{~cm}$ in height, respectively. Plants were identified to species with the exception of sedges, grasses, and 
mosses. Botanical nomenclature followed Kartesz (1999). Authorities and common names are provided in Appendix 5.A; Table 5.A.1. In the $1 \mathrm{~m}^{2}$ quadrants, we measured percent cover of exposed mineral soil and coarse woody debris. The decay stage of coarse woody debris segments was ranked on a scale from 1 (no decay) to 5 (highly decayed) according to Jenkins et al. (2004). Light availability was measured in each $1 \mathrm{~m}^{2}$ herbaceous-layer plot by taking a hemispheric fisheye photograph at $1.37 \mathrm{~m}$ height directly above the quadrant center. We computed diffuse and direct under canopy radiation (mean direct and diffuse photosynthetically active flux density; $\mathrm{mol} \mathrm{m}^{-2} \mathrm{day}^{-1}$ ) from the fisheye photographs using the computer software WinSCANOPY (2005). Stand structure and light environment were measured one year after disturbance (July 2007), while understory vegetation was sampled for three consecutive years (July 2007, 2008, and 2009).

\subsubsection{Data Analyses}

Kruskal-Wallis tests were used to examine differences in environmental variables between disturbance types and the undisturbed area one year after disturbance (July 2007). Environmental variables included aspect (after cosine transformation), overstory basal area, coarse woody debris decay classes 1-3 (low decay coarse woody debris) and 4-5 (high decay coarse woody debris), diffuse under-canopy radiation, direct undercanopy radiation, exposed mineral soil, percent slope, and sapling density. If a significant difference was found $(p<0.05)$ then we conducted post-hoc pairwise comparisons using Mann-Whitney tests, where significance was determined using Bonferroni-adjusted $P$ values. We used nonparametric statistical tests because most of the environmental variables did not meet the assumption of normality after Box-Cox transformation. Kruskal-Wallis and Mann-Whitney tests were also used to examine differences in seedling density between disturbance types as well as adjacent years. Statistical tests were conducted in Minitab Release 16 (Minitab Inc. 2010).

We used a nonmetric multidimensional scaling ordination (NMDS) to examine complex patterns in herbaceous-layer vegetation (McCune and Grace 2002). NMDS is a non-parametric method that is useful for examining patterns in multivariate plant 
community data (Clarke 1993; McCune and Grace 2002). We conducted the NMDS using Sørensen's (Bray-Curtis) distance measure in autopilot mode in PC-ORD 5 (McCune and Mefford 2006). Within each $100 \mathrm{~m}^{2}$ plot, we calculated the mean percent cover of each species between the three $1 \mathrm{~m}^{2}$ quadrants in each year. Percent cover data were arcsine square root-transformed to reduce the stress and improve the interpretability of the NMDS ordination (McCune and Grace 2002). Rare species with a frequency of $<$ $5 \%$ were excluded from the analysis. The arcsine square root transformation and removal of rare species reduced the stress of the best solution from 25.0 to 14.2, which is an improvement from an unacceptable to acceptable level of stress (Clarke 1993). Kendall's $\tau$ rank correlation coefficient was used to examine relationships between each axis and each species as well as the environmental variables listed previously.

A Multiple Response Permutation Procedure (MRPP) was used to test for differences in species composition between disturbance types. MRPP compares withingroup to between-group distances between sample units (Miekle and Berry 2001; McCune and Grace 2002). The analysis is carried out by first computing a distance matrix, and then an effect size (chance-corrected within-group agreement, $A$ ) that describes the observed within-group homogeneity compared to expected homogeneity due to chance. Values of $A$ range from 1 when there is complete agreement within groups, to 0 when within-group heterogeneity equals random expectation, and can be less than 0 if within-group agreement is less than random expectation. We used Sørensen's distance measure to maintain consistency with the NMDS. We carried out three separate MRPP analyses to test for compositional changes between disturbance types each year after disturbance. If a difference was found, we conducted an indicator species analysis (ISA) (Dufrêne and Legendre 1997) to determine which herbaceous-layer species were more prevalent in a given disturbance type. In ISA, an indicator value $(I V)$ is computed for each species in each disturbance type by multiplying relative abundance by relative frequency and multiplying by 100 . To determine if a species' maximum $I V$ was significant, we conducted a Monte Carlo test of significance with 10,000 randomizations (McCune and Grace 2002). We used an alpha level of 0.05 and minimum $I V$ of 25 to determine significance (Dufrêne and Legendre 1997). We used PC-ORD 5 (McCune and Mefford 2006) to conduct all multivariate statistical analyses. 
We examined differences in the rates of species change over time by computing directional vectors between plot-level NMDS ordination scores from each year of the study. Vectors were standardized by subtracting the tail score from both the head and tail scores, which shifts the tails of all vectors to the plot origin and allows direct comparison between head scores (McCune and Grace 2002). We used MRPP with Bonferroniadjusted pairwise comparisons to test for differences in species compositional change between disturbance types from one to two and two to three years after disturbance. Euclidean distance was used because NMDS scores can be less than 0 .

\subsection{Results}

\subsubsection{Environmental Variables}

The fire affected both the overstory and ground-layer environment, while dozer scarification primarily affected environmental variables on the ground (Fig. 5.2). Direct under-canopy radiation was greater in the burned area than either the scarified or undisturbed areas $(H=19.05 ; d f=2 ; P<0.001$; Fig. 5.2A). Diffuse under-canopy radiation was greatest in the burned area, intermediate in the scarified area, and lowest in the undisturbed area $(H=24.29 ; d f=2 ; P<0.001$; Fig. 5.2B $)$. Live basal area was greater in the undisturbed and scarified areas than in the burned area $(H=11.68 ; d f=2 ; P$ $=0.003$; Fig. $5.2 \mathrm{C}$ ). Soil scarification resulted in more exposed mineral soil than burning $(H=18.50 ; d f=2 ; P<0.001 ;$ Fig. 5.2D). Percent cover of low decay coarse woody debris did not differ by disturbance type $(H=1.34 ; d f=2 ; P=0.512)$, although variance appeared to be greater in the undisturbed area (Fig. 5.2E). Percent cover of high decay coarse woody debris was greater in the burned area compared to the scarified area, and was intermediate in the undisturbed area $(H=7.57 ; d f=2 ; P=0.023$; Fig. 5.2F $)$. High decay coarse woody debris was absent from the scarified area. Scarification also removed all woody saplings, although post-fire sapling density did not differ from the undisturbed understory $(H=16.05 ; d f=2 ; P<0.001$; Fig. 5.2G).

The disturbed areas had greater slopes than the undisturbed area $(H=10.26 ; d f=$ $2 ; P=0.006$; Fig. 5.2H $)$ although aspect did not differ $(H=2.89 ; d f=2 ; P=0.236$; Fig. 
5.2I). Patterns in under-canopy radiation were more similar to basal area than slope (Fig. 5.2), implying that basal area had a greater influence on radiation.

\subsubsection{Seedling density}

Soil scarification by bulldozer facilitated the greatest eastern hemlock seedling density of the two disturbance types and the undisturbed forest during each year of the study ( 1 year: $H=12.9, d f=2 ; P=0.002 ; 2$ years: $H=20.9, d f=2 ; P<0.0001 ; 3$ years: $H=19.8, d f=2 ; P<0.0001$; Kruskal-Wallis test results) (Fig. 5.3). In the scarified area, hemlock seedling density increased from the first to second years after disturbance ( $W=$ 73.5; $P=0.037$; Mann-Whitney test results), but did not increase from the second to third years ( $W=120 ; P=0.542)$ (Fig. 5.3B). In the burned and undisturbed areas, hemlock seedling density remained consistently lower over the three-year study (Fig. 5.3A, 5.3C). Hemlock was also a significant indicator species of the scarification disturbance during all three years of the study, based on percent cover (Table 5.1). In addition to hemlock, red maple was also a significant indicator species of soil scarification (Table 5.1). Red maple seedling density was greatest in the scarified area throughout the study (1 year: $H$ $=21.1, d f=2, P<0.0001 ; 2$ years: $H=21.2, d f=2 ; P<0.0001 ; 3$ years: $H=19.0, d f=$ 2; $P<0.0001)$. Compared to hemlock seedling density, red maple was 16 times more abundant in the first year after disturbance and 2.5 times more abundant in the second and third years. Changes in red maple seedling density over time were not statistically significant (1-2 years: $W=127 ; P=0.208,2-3$ years: $W=127.5 ; P=0.192)$. Northern white-cedar became a significant indicator species of scarification by the third year of the study (Table 5.1), with a seedling density of 32,667 $\pm 58,348$ seedlings ha ${ }^{-1}$.

In the burned area, paper birch and red maple seedlings were the most abundant trees (Fig. 5.3A). Both of these species are often associated with post-fire vegetation, especially paper birch. However, paper birch was not a significant indicator of fire even by the third year of the study $(I V=15.6 ; P=0.86)$. Red maple seedling density remained relatively constant over the three-year study, from 7,000 $\pm 12,217$ seedlings ha $^{-1}$ in the first year to $5,333 \pm 3,583$ seedlings ha ${ }^{-1}$ in the third year. Rubus spp. shrubs composed most of the woody seedling community by the second $\left(47,333 \pm 42,855\right.$ seedlings ha $\left.{ }^{-1}\right)$ 
and third (82,667 $\pm 66,198$ seedlings $\left.\mathrm{ha}^{-1}\right)$ years after disturbance (Fig. 5.3A). Rubus spp. was also a significant indicator of fire each year of the study (Table 5.1).

Sugar maple and red maple were the most abundant seedlings in the undisturbed reference plots based on seedling density (Fig. 5.3C), but neither species was a significant indicator based on cover. Sugar maple seedling density was highly variable and decreased by half from the first year $\left(97,000 \pm 222,813\right.$ seedlings $\left.\mathrm{ha}^{-1}\right)$ to the second year $\left(41,667 \pm 89,708\right.$ seedlings $\left.\mathrm{ha}^{-1}\right)$ of the study, and leveled off by the third year $(48,333 \pm$ 110,680 seedlings $\mathrm{ha}^{-1}$ ). Red maple seedling density remained similar from the first $\left(28,667 \pm 31,903\right.$ seedlings $\left.\mathrm{ha}^{-1}\right)$ to the second year $\left(24,667 \pm 36,589\right.$ seedlings $\left.\mathrm{ha}^{-1}\right)$, but declined by the third year $\left(9,333 \pm 14,212\right.$ seedlings $\left.\mathrm{ha}^{-1}\right)$. High inter-annual variability in seedling density is common, and may be due to fluctuations in seed production (Houle 1999). Both species exhibited a clumped spatial distribution as demonstrated by large standard deviations relative to the mean density, which may explain why sugar maple was not a significant indicator species despite its high mean abundance. There were no indicator species from the undisturbed plots.

\subsubsection{Herbaceous-layer plant communities}

The NMDS ordination resulted in a three-axis solution explaining $82 \%$ of the variation in the data structure, and with a final stress of 14.2 and an instability $<0.001$ in 380 iterations. The three axes explained $30 \%, 20 \%$, and $32 \%$ of the variation, respectively. Among the environmental variables, diffuse and direct under-canopy radiation were generally the most correlated with NMDS axes. Axis 1 was most positively correlated with basal area $(\tau=0.211)$ and negatively correlated with diffuse under-canopy radiation $(\tau=-0.505)$, direct under-canopy radiation $(\tau=-0.397)$, and slope $(\tau=-0.251)$. Axis 2 was most positively correlated with slope $(\tau=0.323)$ and diffuse under-canopy radiation $(\tau=0.234)$ and negatively correlated with high decay coarse woody debris $(\tau=-0.212)$. Similarly to axis 1 , axis 3 was most positively correlated with basal area $(\tau=0.215)$ and negatively correlated with diffuse under-canopy radiation $(\tau=$ $0.424)$ and direct under-canopy radiation $(\tau=-0.295)$. 
Based on the MRPP, plant communities varied significantly by treatment type during each year of the study ( 1 year: $A=0.201, P<0.001$; 2 years: $A=0.289, P<$ $0.001 ; 3$ years: $A=0.265, P<0.001)$. Pairwise comparisons using Bonferroni-adjusted $P$-values indicated that the disturbance types differed from one another and the control one year (2007) and two years (2008) after the burn, but by year three (2009) plant communities in the scarified area did not differ from those in the undisturbed area $(A=$ $0.050 ; P=0.105)$. The ISA revealed different dominant species in each disturbance type, with all indicators of the fire being graminoids, forbs, shrubs, and ferns while the scarified area was experiencing significant tree seedling regeneration. In the first year after the burn, four species were more abundant and frequent in the burned area: grasses, the forb Polygonum cilinode, the fern Pteridium aquilinium, and the shrubs Rubus spp. (Table 5.1). In the second year four additional species became significant indicators of the burned area and remained so in the third year: Carex spp., the forbs Cirsium spp. and Epilobium ciliatum, and the shrub Vaccinium angustifolium (Table 5.1). In the scarified area, red maple and eastern hemlock seedlings were the only significant indicators one and two years after disturbance, and northern white-cedar became an indicator in the third year (Table 5.1). There were no significant indicator species in the undisturbed area during any year (Table 5.1). Species that were indicators of fire tended to be the most negatively correlated with NMDS axes 1 and 3, which were also negatively correlated with direct and diffuse under-canopy radiation and positively correlated with basal area. Eastern hemlock, an indicator species in the scarified area, was the most positively correlated species with axis 3 , which was negatively correlated with under-canopy radiation and positively correlated with basal area.

Species composition changed more rapidly in the burned area than the scarified or undisturbed areas in the first two years after disturbance, but this change decreased by the third year. The MRPP of standardized NMDS scores revealed significant differences between treatments in species change from one to two years $(A=0.099 ; P<0.001)$ and from two to three years $(A=0.056 ; P=0.012)$ after disturbance. However, an examination of trends in pairwise comparisons and vector plots (Fig. 5.4) suggests that the significant result from years two to three is due in large part to an outlier in the reference area. Based on pairwise comparisons of Bonferroni-adjusted $P$-values, the 
change in community composition from years one to two was greater in the burned area than the scarified $(A=0.090 ; P=0.009)$ or undisturbed $(A=0.089 ; P=0.012)$ area, while the scarified and undisturbed area did not differ from one another $(A=0.048 ; P=$ $0.135)$. From years two to three, the burned area did not differ from the scarified area $(A$ $=0.007 ; P=0.888)$ or the undisturbed area $(A=0.028 ; P=0.283)$, but the scarified and undisturbed areas were significantly different $(A=0.083 ; P=0.010)$. Due to the single outlier in the reference area and the relatively low $A$, we conclude that differences in NMDS vectors from years two to three are not likely ecologically significant even if they are significant statistically.

\subsection{Discussion}

Eastern hemlock regeneration was more likely to occur following an understory disturbance that exposed mineral soil and reduced herbaceous-layer competition compared to either canopy removal by fire or a lack of disturbance. In our study, soil scarification by a bulldozer increased exposure of the mineral soil and eliminated competition from the sapling layer without substantially altering understory light levels. This combination of environmental factors allowed hemlock seedlings to establish more readily compared to burning and lack of disturbance. Red maple seedlings established rapidly after scarification, but were decreasing in abundance by the third year after disturbance. Paper birch seedlings were not among the most abundant species in the burned area as we expected. Herbaceous and shrub species that are often associated with crown fire and other canopy disturbances increased in cover during the 3-year study period. In the adjacent undisturbed area, no herbaceous-layer species was consistently abundant enough to be considered a significant indicator. Although we recorded several species commonly associated with hemlock forest, including Maianthemum canadense, Trientalis borealis, Dryopteris sp., Oxalis sp., Coptis trifolia, Lycopodium spp., and Carex spp. (Godman and Lancaster 1990), they were present in low abundance and frequency (Table 5.A.1).

Our results corroborate and augment previous silvicultural recommendations for hemlock, based on hemlock life history and case studies. Hemlock is a long-lived (up to 
800 years), slow-growing (up to 250-300 years to reach maturity), and highly shadetolerant conifer (Godman and Lancaster 1990). A mature tree produces copious amounts of seed annually, but successful seedling establishment is rare (Godman and Lancaster 1990). Soil conditions that increase the success of establishment are warm temperatures $\left(7^{\circ}-18^{\circ} \mathrm{C}\right)$, high moisture content (Godman and Lancaster 1990), and a suitable germination substrate of exposed mineral soil or coarse woody debris (Rooney and Waller 1998; Marx and Walters 2008; Witt and Webster 2010). Hemlock seedlings rarely germinate through thick, dense litter layers (Rooney and Waller 1998; Witt and Webster 2010). Natural hemlock regeneration is increased by single treefall events that disturb the soil and create a small canopy opening (Eckstein 1980; Mladenoff and Stearns 1993). Silvicultural recommendations for germinating hemlock include soil preparations of mixing the organic and upper mineral horizons or burning with a surface fire (Godman and Lancaster 1990). Greater seedling densities have been observed where the soil was mechanically scarified by a bulldozer and rock rake (Becker et al. 1996), and following a prescribed burn (Pubanz 1996). In a greenhouse experiment using excavated soil monoliths, seedling emergence was greatest when the organic layer was removed compared to burning or retaining the organic layer (Duchesne et al. 1999).

Although hemlock seedling establishment occurred in the scarified area, successful hemlock regeneration may be tempered by drought. Mladenoff and Stearns (1993) hypothesized that successful hemlock regeneration after a disturbance event depends on climatic conditions in the decades after disturbance. Paleoecological studies have indicated that hemlock's range expanded and contracted with changes in temperature and precipitation in the northern United States and southern Canada during the Holocene epoch (Calcote 2003; Foster et al. 2006). For example, prior to 3500-3000 years before present, sites currently occupied by hemlock in the northern Lake States were likely dominated by white pine (Frelich et al. 1993; Davis et al. 1998). The transition to hemlock dominance corresponded with increased moisture availability and decreased fire frequency across the region. During our 3-year study, northern Wisconsin experienced growing-season drought conditions as demonstrated by the Palmer Drought Severity Index (PDSI) (National Climatic Data Center 2012) during all but the second year (2008), which was near average (Fig. 5.5). The second year corresponded with an 
increase in hemlock seedling density as well as northern white-cedar, another species whose seedlings are sensitive to desiccation (Johnston 1990). Seedling density of these species did not continue to increase in the third year when drought conditions returned. Although our study occurred over a short time scale of 3 growing seasons, our results corroborate other studies that suggest hemlock's range may contract if drier growingseason conditions accompany warming temperatures (Iverson et al. 2008). Recent climate models predict increased growing season temperatures in the northern Great Lakes region over the next century, with high uncertainty for precipitation (Hayhoe et al. 2010). If consistently moist growing season conditions become less frequent in hemlock-hardwood forests, then species whose seedlings are less susceptible to desiccation are likely to capture disturbed sites at the expense of hemlock.

Red maple is one species that could potentially increase in response to drought and disturbance in hemlock-hardwood forests, at least in the immediate future. Red maple is a habitat generalist that has thrived in North America following European settlement, due in part to increased rates of forest disturbance (Abrams 1998). Hibbs (1982) reported that red maple seedlings grew faster than hemlock seedlings in hemlock-hardwood forest canopy gaps. Although red maple often fails to dominate the canopy due to decreasing shade tolerance with tree size, Walters and Yawney (1990) report cases of overstory red maple density increasing following disturbance. In the current study, red maple seedlings established at high densities in the scarified plots even during the drought year of 2007. Red maple seedling density was similar to that of paper birch in the burned area, suggesting that red maple trees may eventually be present in the burned area as well. An important caveat of our hypothesis is that areas with high white-tailed deer populations may not see an increase in red maple because it is a preferred browse species (Salk et al. 2011). We did not observe a great amount of browse damage at our study site, and the seedlings we censused were not yet tall enough to be browsed by deer.

Forest herbaceous-layer vegetation functions as a filter for overstory regeneration. Initial post-disturbance vegetation communities greatly affect both the future overstory composition and rate of succession (George and Bazzaz 2003). In the burned area of our study, the establishment of low-stature ferns, shrubs, and graminoids may be slowing the establishment of tree seedlings. George and Bazzaz (1999) observed significantly 
reduced seedling germination and establishment of sweet birch (Betula lenta) and yellow birch in the presence of ferns, whereas red maple seedlings were not negatively impacted by ferns. Rubus spp. is known to rapidly increase in cover in post-fire forest understories, reducing the rate of seedling establishment (Donoso and Nyland 2006). In the burned area of our study, it is conceivable that Rubus spp. suppressed tree seedling establishment given that it was 11 times more abundant than the most abundant tree seedling paper birch. However, Rubus spp. may eventually facilitate tree regeneration by protecting seedlings from desiccation and increasing nitrogen availability (Donoso and Nyland 2006). At three years after fire, it is unclear which tree species will achieve canopy dominance in our study site, but rapid increases in herbaceous and shrub densities are likely slowing the rate of succession.

\subsection{Conclusions}

Our results suggest that soil scarification is a useful method of regenerating eastern hemlock in hemlock-hardwood forests, but the climatic conditions that follow soil disturbance may modulate regeneration success. Although fire is not facilitating immediate hemlock re-establishment in the current study, several cases of fire-origin hemlock stands have been observed. Although we cannot test this hypothesis with our current data, we suggest that these stands may have regenerated when wetter climate conditions followed a fire. Therefore, hemlock and other late-successional temperate tree species may be difficult to regenerate, especially if the climate in temperate regions becomes warmer as predicted. Where hemlock regeneration is desired, planting of saplings and/or removal of competitors may help to circumvent the potential consequences of drought.

Forest management actions that focus on foundation species such as hemlock are more likely to achieve broad success by preserving the ecological interactions associated with the focal species. In unmanaged forest of the upper Great Lakes region, current rates of hemlock regeneration are insufficient to maintain regional hemlock dominance (Frelich and Lorimer 1985; Salk et al. 2011), although regeneration may be abundant in select locations (Witt and Webster 2010). Past extirpations of foundation species, such as 
American chestnut (Castanea dentata), have led to widespread and unpredictable ecosystem change (Ellison et al. 2005). Therefore, appropriate management of existing foundation species is important to conservation of forest ecosystem function. 


\subsection{Tables and Figures}

Table 5.1: Significant indicator species by disturbance type after one, two, and three years since disturbance.

\begin{tabular}{|c|c|c|c|c|c|}
\hline Species & $\begin{array}{c}\text { Taxonomic } \\
\text { group }\end{array}$ & $\begin{array}{c}\text { Disturbance } \\
\text { type }^{\mathrm{a}}\end{array}$ & $\begin{array}{l}\text { Obs. } \\
I V^{\mathrm{b}}\end{array}$ & $\begin{array}{l}\text { Rand. } \\
I V^{\mathrm{c}}\end{array}$ & $P$ \\
\hline \multicolumn{6}{|c|}{ 2007; one year after disturbance } \\
\hline Pteridium aquilinium & Cryptogam & $\mathrm{F}$ & 57.1 & $22.6(7.78)$ & 0.002 \\
\hline Grasses & Graminoid & $\mathrm{F}$ & 54.9 & $18.9(7.61)$ & 0.003 \\
\hline Rubus spp. & Shrub & $\mathrm{F}$ & 49.4 & $25.9(7.45)$ & 0.013 \\
\hline Polygonum cilinode & Forb & $\mathrm{F}$ & 40.6 & $23.6(7.57)$ & 0.034 \\
\hline Acer rubrum & Tree & S & 53.2 & $34.9(4.61)$ & $<0.001$ \\
\hline Tsuga canadensis & Tree & $\mathrm{S}$ & 48.6 & $29.3(6.48)$ & 0.013 \\
\hline \multicolumn{6}{|c|}{ 2008; two years after disturbance } \\
\hline Polygonum cilinode & Forb & $\mathrm{F}$ & 78.9 & $24.1(7.86)$ & $<0.001$ \\
\hline Rubus spp. & Shrub & $\mathrm{F}$ & 75.3 & $26.4(7.77)$ & $<0.001$ \\
\hline Grasses & Graminoid & $\mathrm{F}$ & 67.2 & $26.6(8.14)$ & 0.001 \\
\hline Pteridium aquilinium & Cryptogam & $\mathrm{F}$ & 57.0 & $21.3(7.77)$ & 0.002 \\
\hline Carex spp. & Graminoid & $\mathrm{F}$ & 52.5 & $40.2(5.94)$ & 0.037 \\
\hline Cirsium sp. & Forb & $\mathrm{F}$ & 40.0 & $14.0(6.76)$ & 0.022 \\
\hline Epilobium ciliatum & Forb & $\mathrm{F}$ & 40.0 & $14.0(6.89)$ & 0.025 \\
\hline Vaccinium angustifolium & Shrub & $\mathrm{F}$ & 40.0 & $14.4(7.09)$ & 0.019 \\
\hline Tsuga canadensis & Tree & $\mathrm{S}$ & 52.7 & $30.8(6.56)$ & 0.004 \\
\hline Acer rubrum & Tree & $\mathrm{S}$ & 43.2 & $36.7(2.23)$ & 0.002 \\
\hline
\end{tabular}


Table 5.1 (continued)

\begin{tabular}{lllccc}
\hline \multicolumn{1}{c}{ Species } & $\begin{array}{c}\text { Taxonomic } \\
\text { group }\end{array}$ & $\begin{array}{c}\text { Disturbance } \\
\text { type }^{\mathrm{a}}\end{array}$ & $\begin{array}{c}\text { Obs. } \\
I V^{\mathrm{b}}\end{array}$ & $\begin{array}{c}\text { Rand. } \\
I V^{\mathrm{c}}\end{array}$ & $P$ \\
\hline 2009; three years after disturbance & & & & \\
$\begin{array}{l}\text { Polygonum cilinode } \\
\text { Rubus spp. }\end{array}$ & Forb & $\mathrm{F}$ & 82.3 & $24.0(8.00)$ & $<0.001$ \\
Grasses & Shrub & $\mathrm{F}$ & 78.0 & $26.6(8.25)$ & $<0.001$ \\
Epilobium ciliatum & Graminoid & $\mathrm{F}$ & 70.5 & $25.3(8.08)$ & 0.001 \\
Carex spp. & Forb & $\mathrm{F}$ & 70.0 & $18.4(7.39)$ & 0.001 \\
Pteridium aquilinium & Graminoid & $\mathrm{F}$ & 57.8 & $40.9(5.64)$ & 0.007 \\
Vaccinium angustifolium & Cryptogam & F & 57.3 & $23.9(7.86)$ & 0.003 \\
Cirsium sp. & Forb & $\mathrm{F}$ & 55.5 & $19.1(7.97)$ & 0.003 \\
Acer rubrum & Tree & $\mathrm{F}$ & 50.0 & $15.9(7.49)$ & 0.007 \\
Tsuga canadensis & Tree & $\mathrm{S}$ & 55.2 & $34.2(5.64)$ & 0.001 \\
Thuja occidentalis & Tree & $\mathrm{S}$ & 54.4 & $30.5(6.47)$ & 0.003 \\
\end{tabular}

${ }^{\mathrm{a}} \mathrm{F}=$ Fire; $\mathrm{S}=$ Scarification; reference site did not contain significant indicator species.

${ }^{\mathrm{b}}$ Observed importance value.

${ }^{\mathrm{c}}$ Mean importance value from randomized groups; standard deviation in parentheses; Monte Carlo test with 10,000 permutations. 


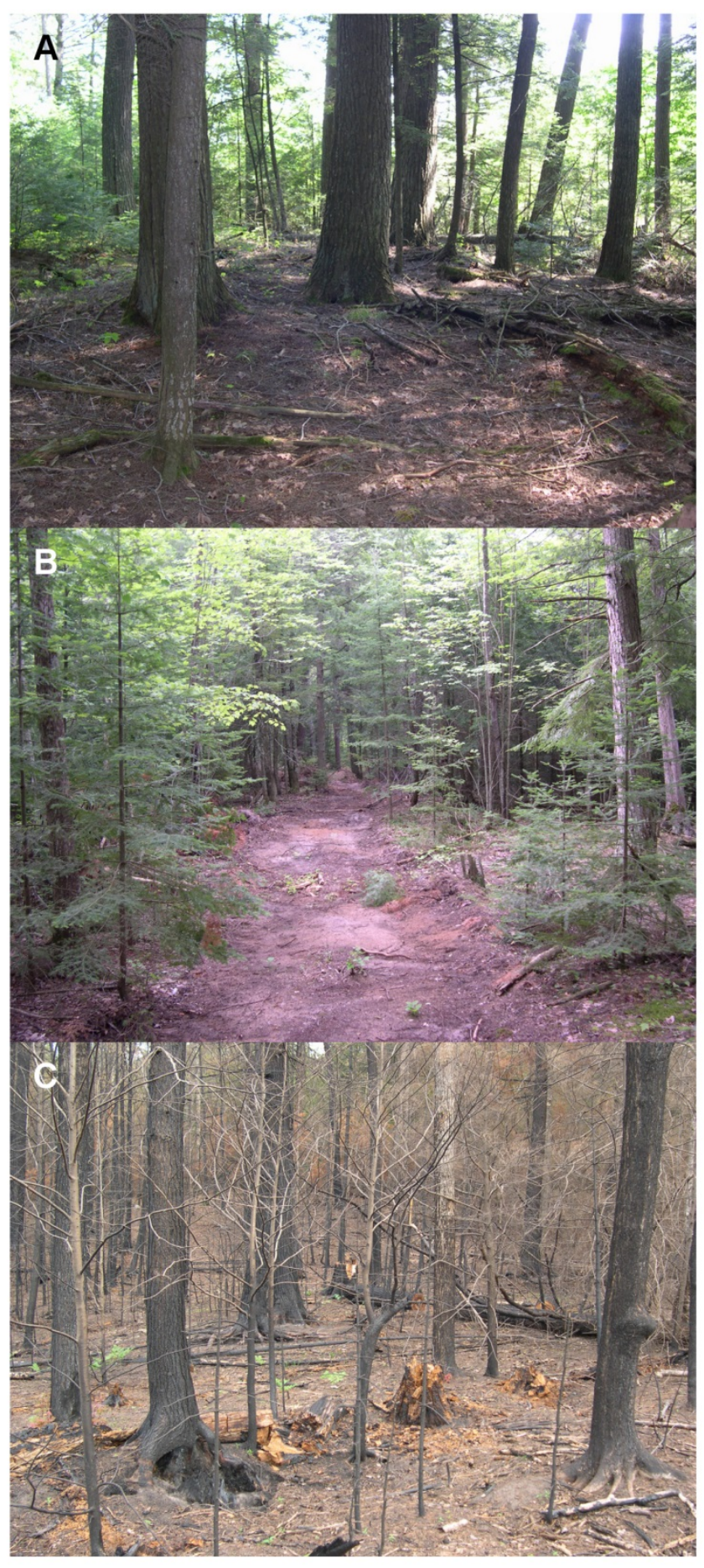

Figure 5.1: Fire and soil scarification effects in hemlock-hardwood forest. (a) Undisturbed hemlock forest was used as a reference site. (b) Soil was scarified by a bulldozer used for fire control. (c) Portion of hemlock forest was burned by a naturalorigin fire in late May 2006. 

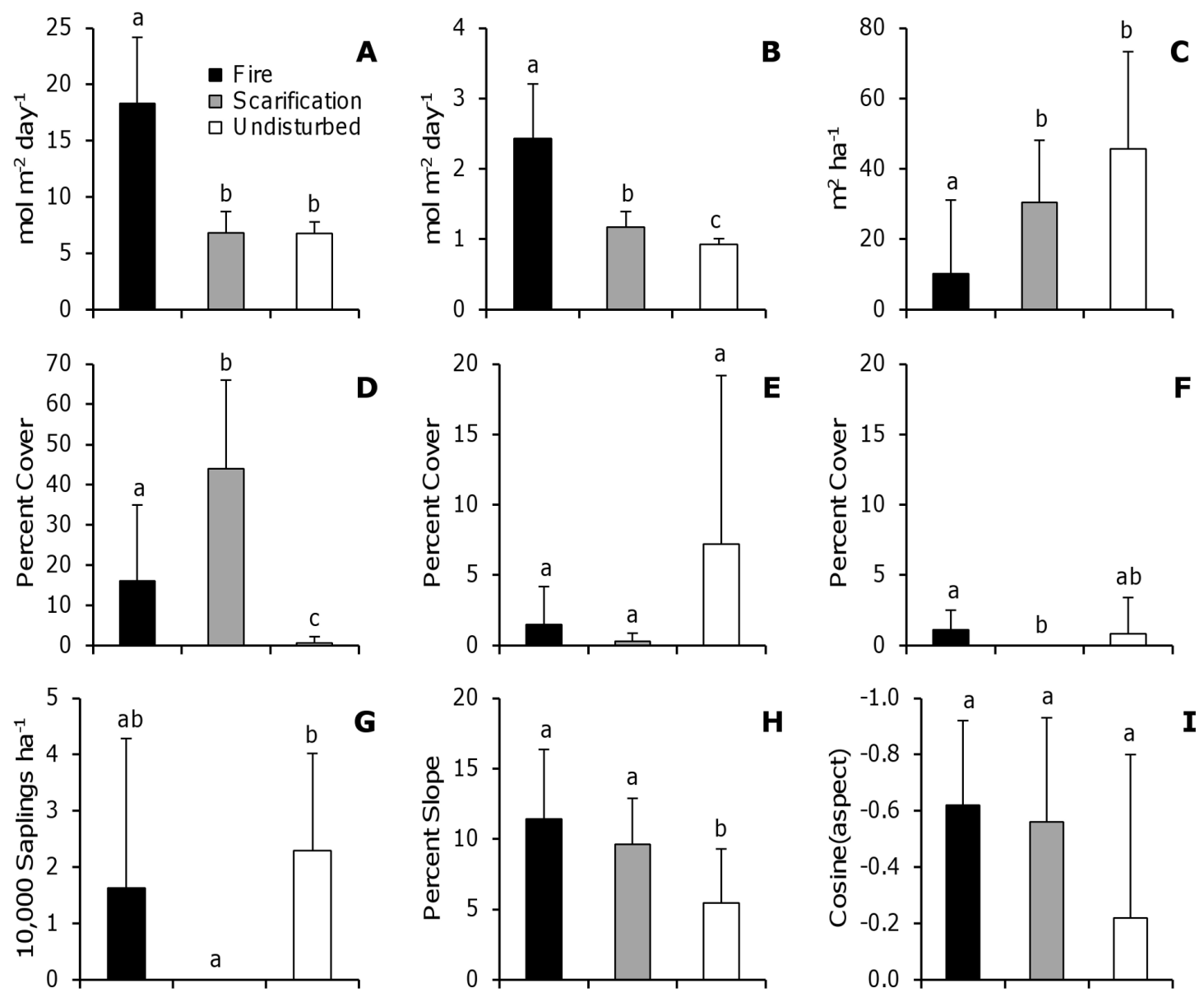

Figure 5.2: Effect of fire and scarification on the understory environment.

Environmental variables (mean \pm 1 standard deviation; $n=10$ ) that were potentially impacted by disturbance: ( $a$ ) direct under-canopy radiation, $(b)$ diffuse under-canopy radiation, $(c)$ basal area, $(d)$ exposed mineral soil, $(e)$ low decay coarse woody debris (decay classes 1-3), $(f)$ high decay coarse woody debris (decay classes 4 and 5), and ( $g$ ) sapling density. Environmental variables that can affect plant communities: (h) slope and (i) aspect. Lowercase letters denote results of Mann-Whitney pairwise comparisons by disturbance type, with different letters indicating significant differences at $\alpha=0.05$. All environmental variables were measured in July 2007, approximately one year after disturbance. 

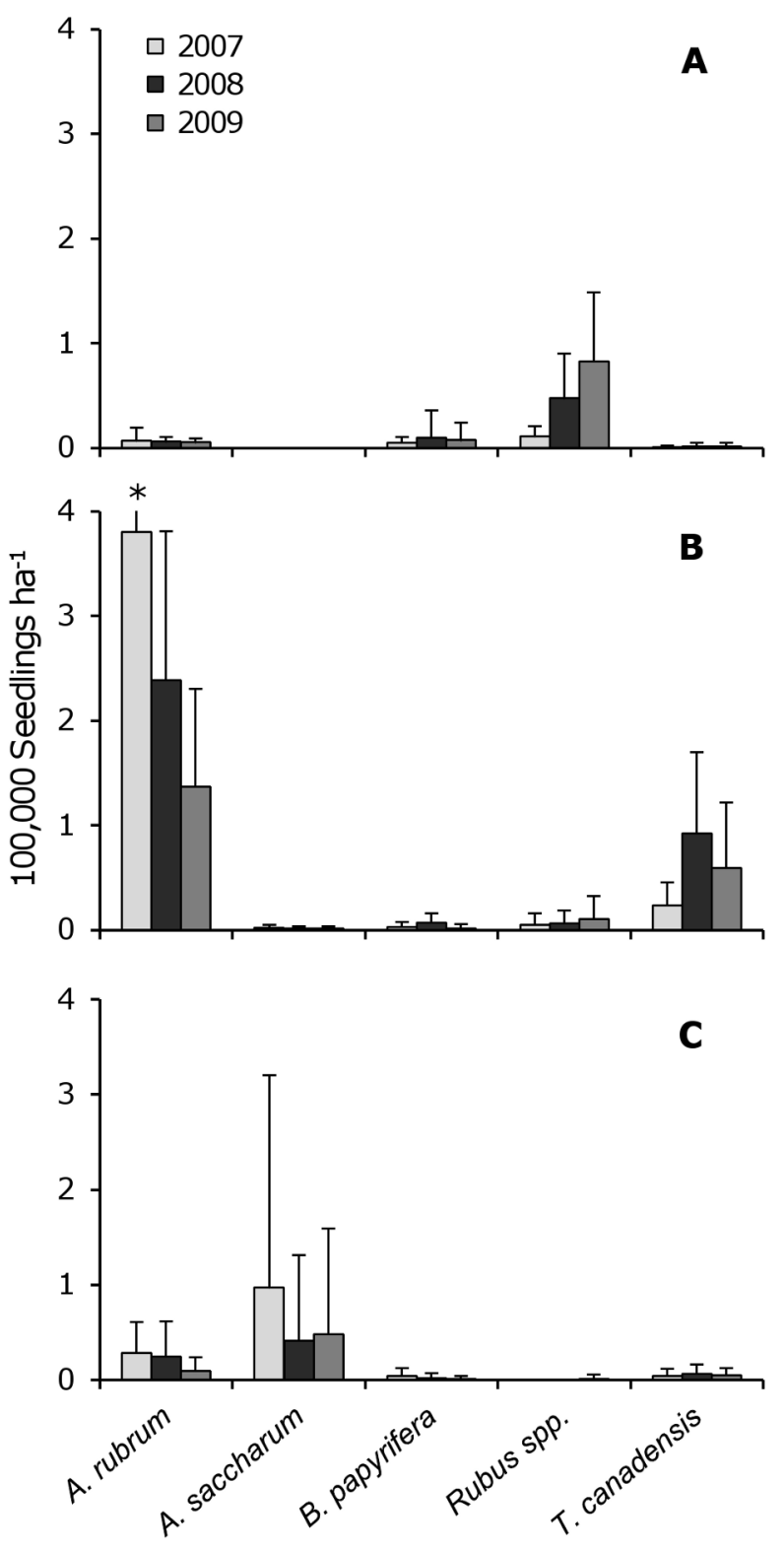

Figure 5.3: Annual changes in seedling densities by disturbance type. Mean seedling density of the five most abundant woody species by time since disturbance (2007: one year; 2008: two years; 2009: three years) and disturbance type: (a) fire, $(b)$ scarification, and (c) undisturbed. Error bars represent one standard deviation $(n=10)$. Asterisks indicate error bars that exceed the figure scale. 

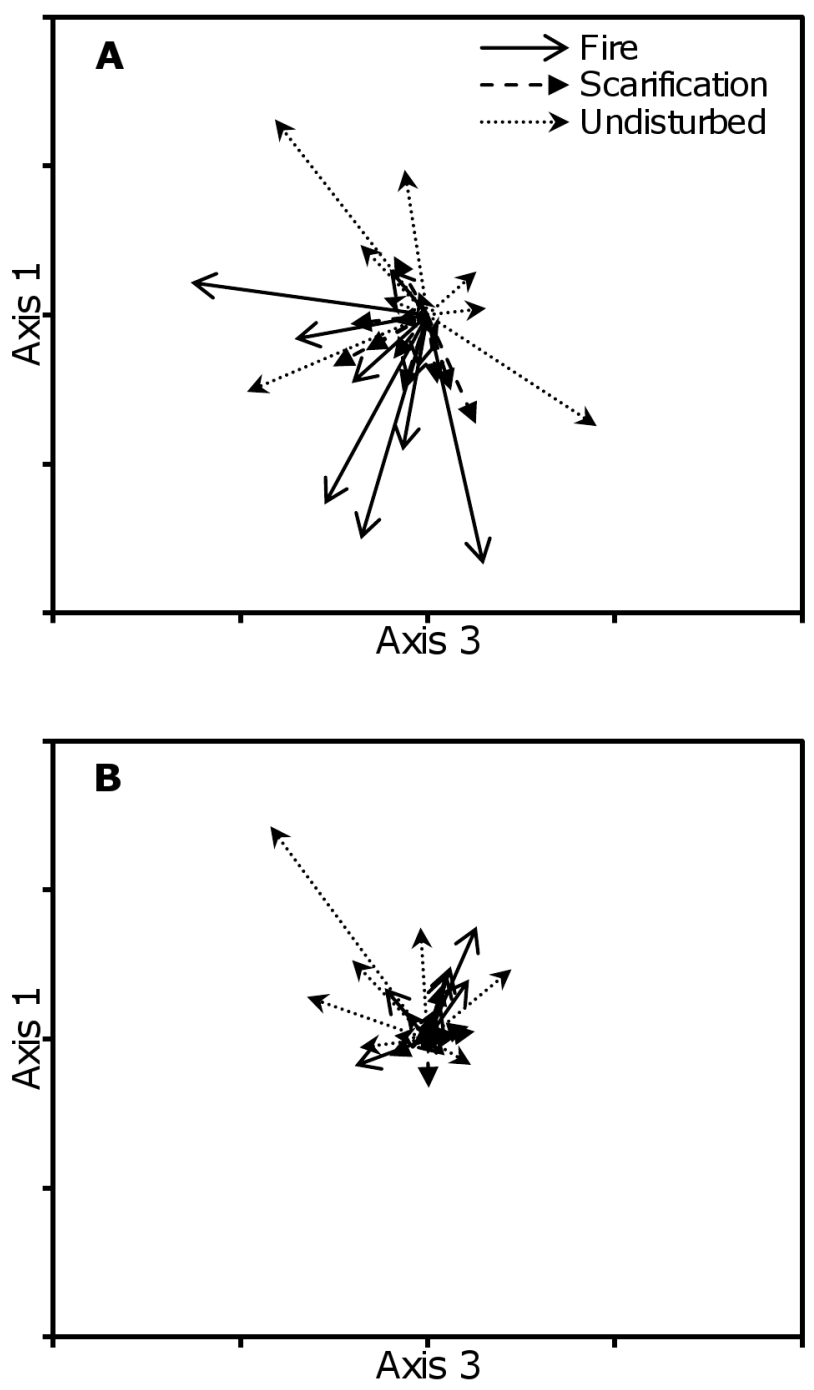

Figure 5.4: Annual herbaceous-layer community change by disturbance type. Nonmetric multidimensional scaling (NMDS) ordination scores depicting relative changes in species composition by disturbance type and years since disturbance. Each vector represents the magnitude and direction of change for each plot from one to two years $(a$; 2007-2008) and two to three years ( $b$; 2008-2009) after disturbance. The NMDS ordination was three-dimensional with a final stress 14.2 and instability $<0.001$ in 380 iterations. Only the two dominant axes are displayed (Axis 3: $r^{2}=0.32$; Axis 1: $r^{2}=0.30$ ) whereas the third axis (Axis $2: r^{2}=0.20$ ) is excluded. 


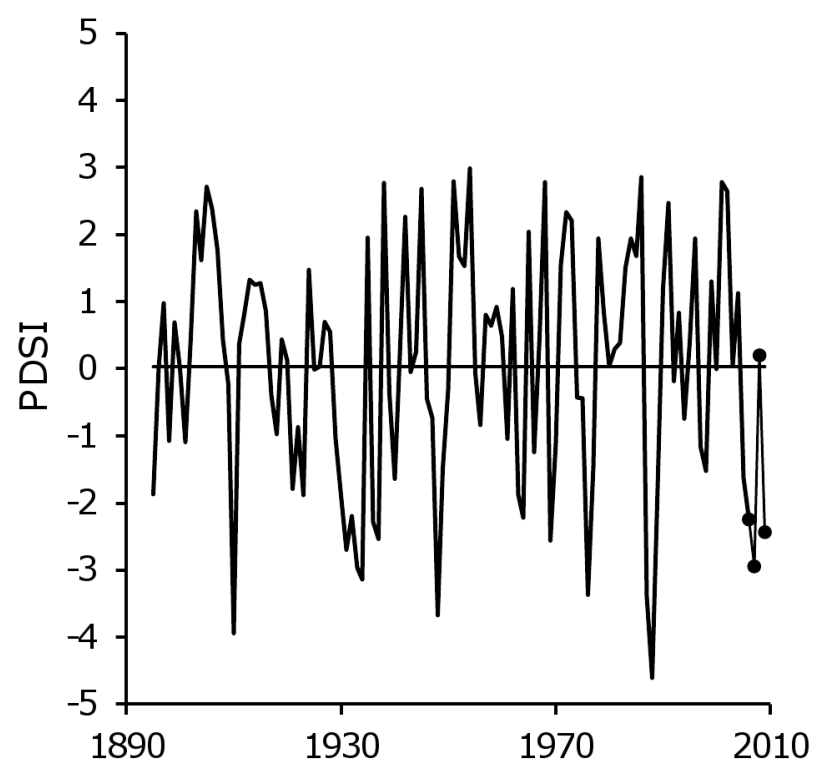

Figure 5.5: Drought conditions occurred in northern Wisconsin during 2007 and 2009. Growing-season (May-September) Palmer Drought Severity Index (PDSI) for Wisconsin Climate Division 1 is plotted by year (National Climatic Data Center, 2012). PDSI values during the sampling period are indicated by dark circles, and the 115-year mean is plotted as a straight line. 


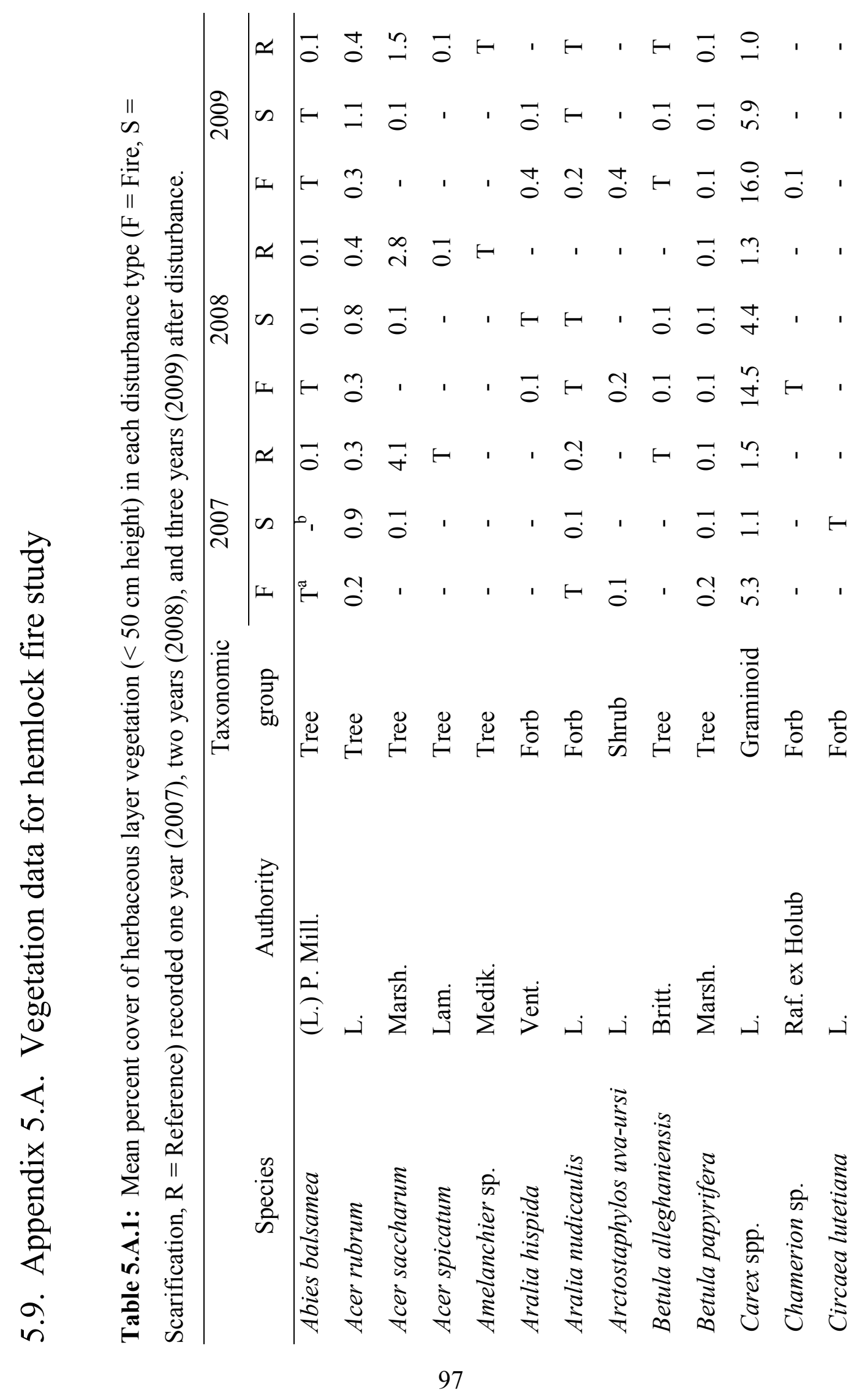




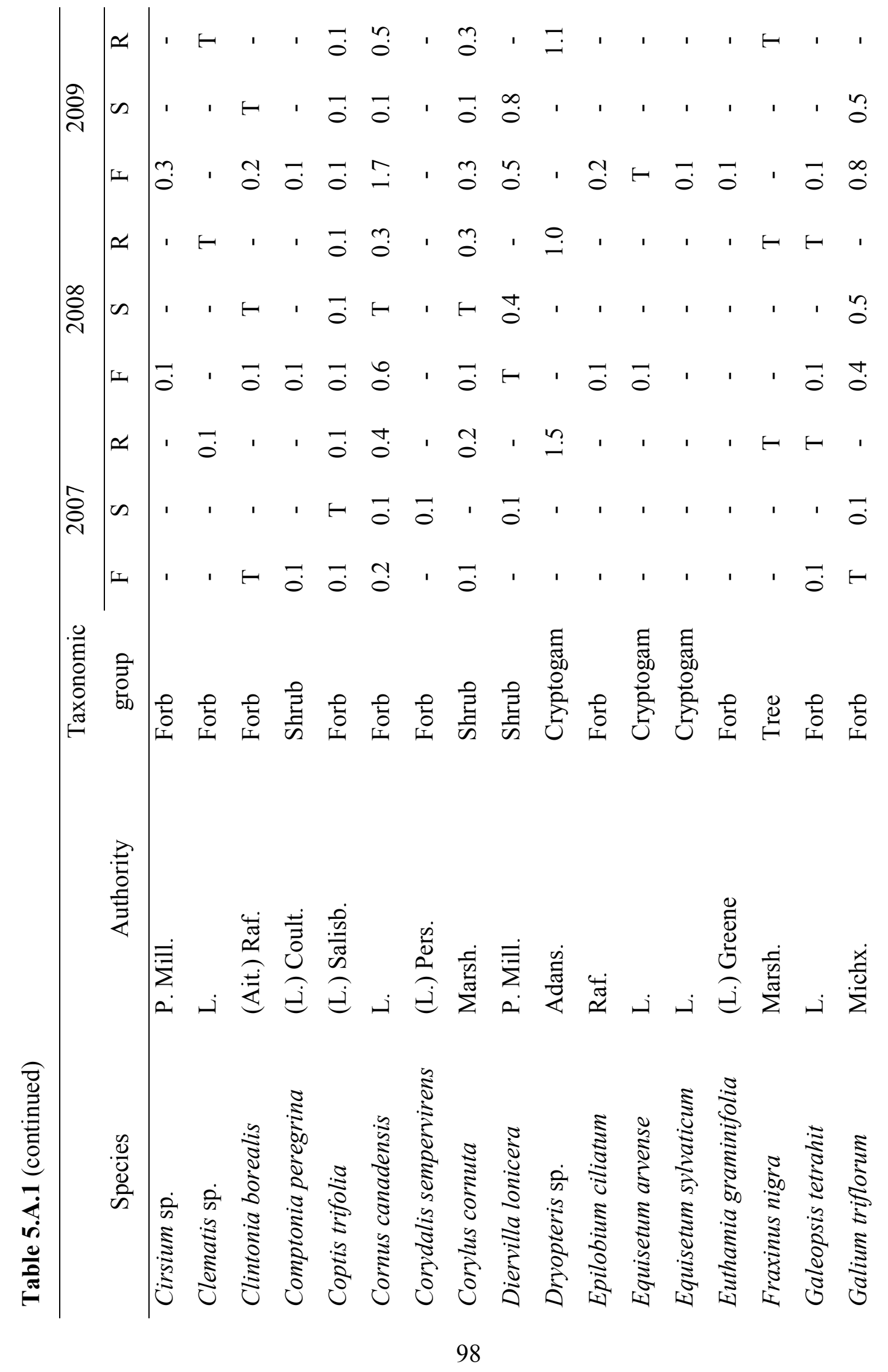




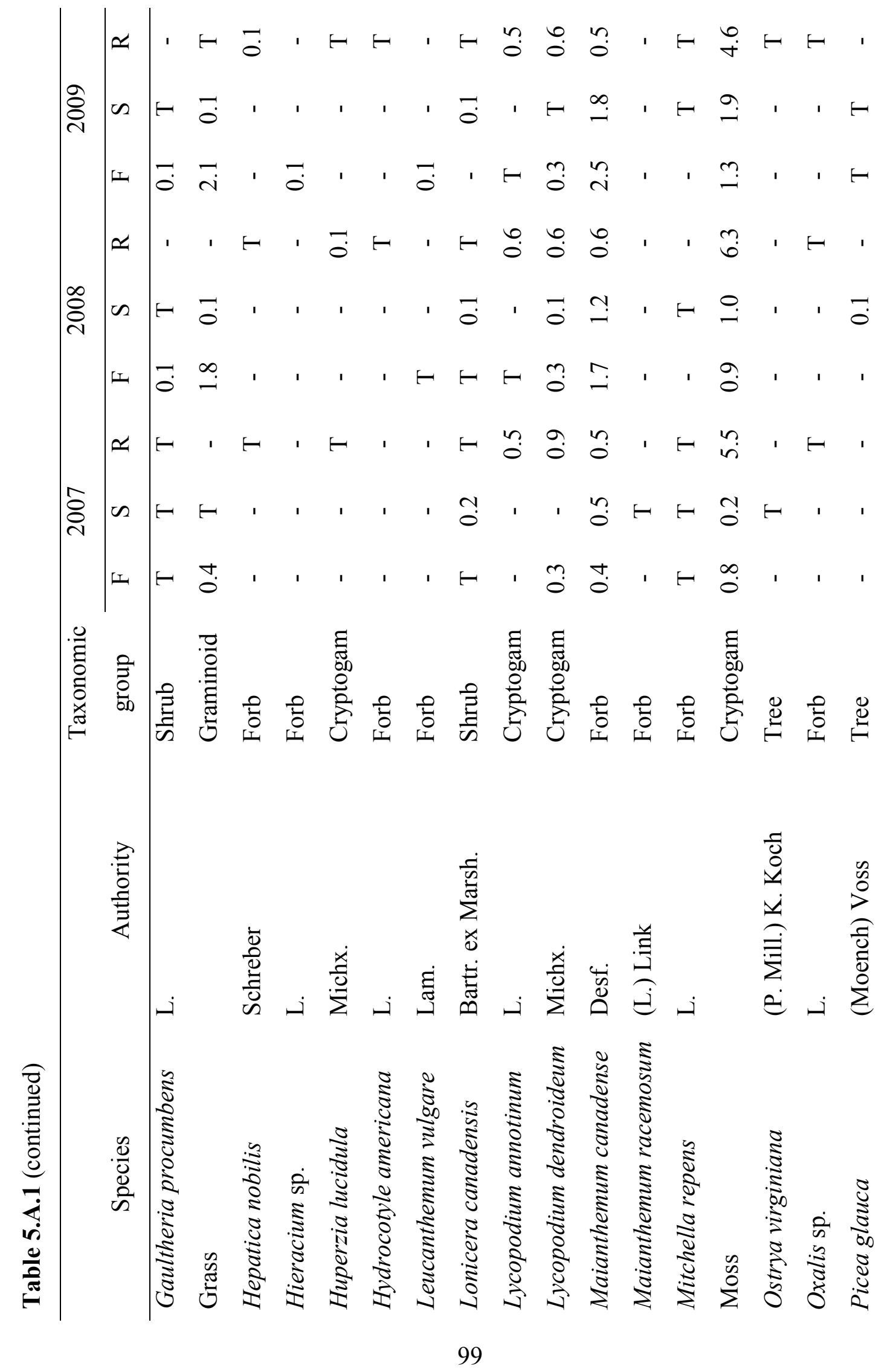




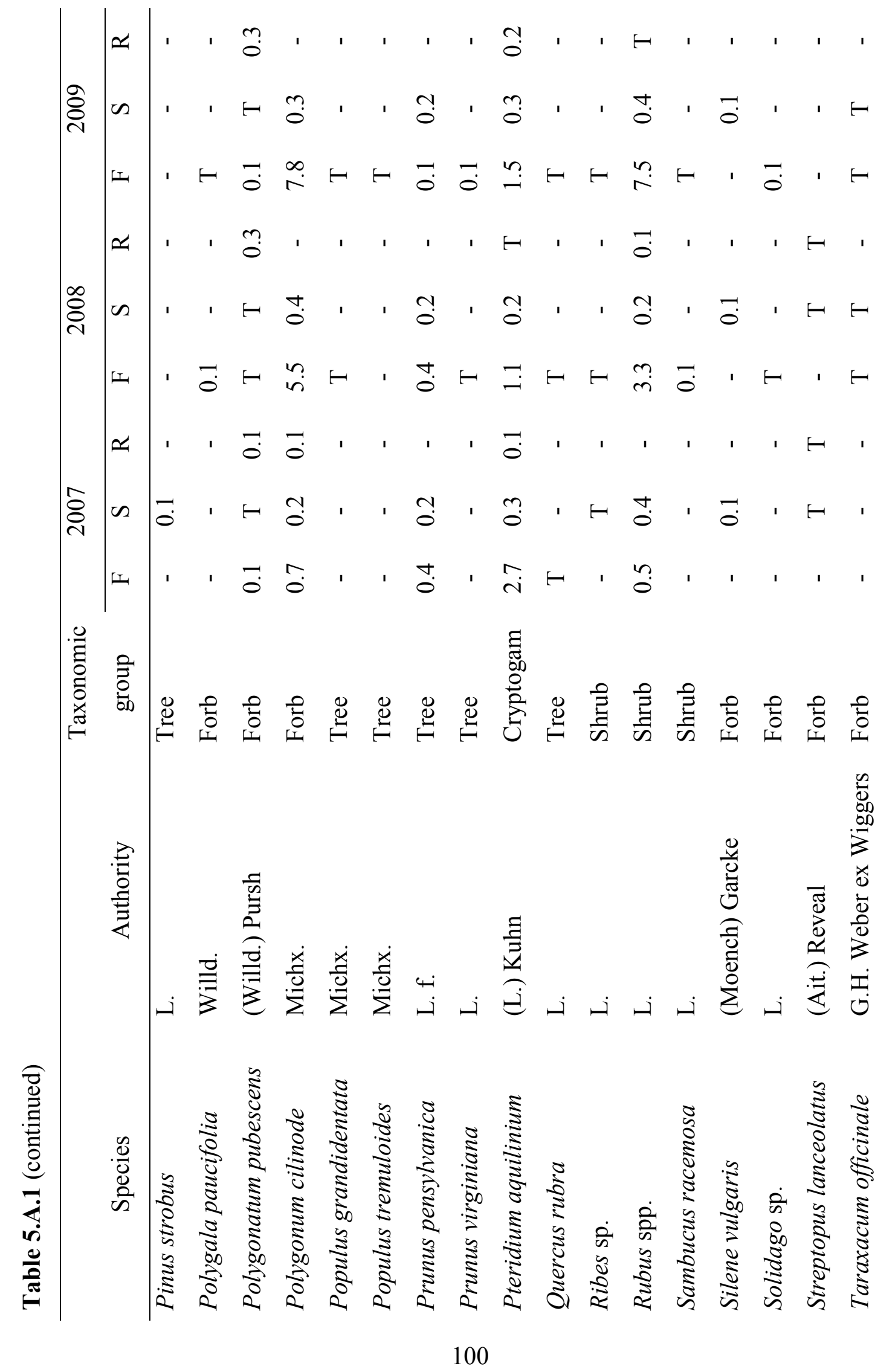




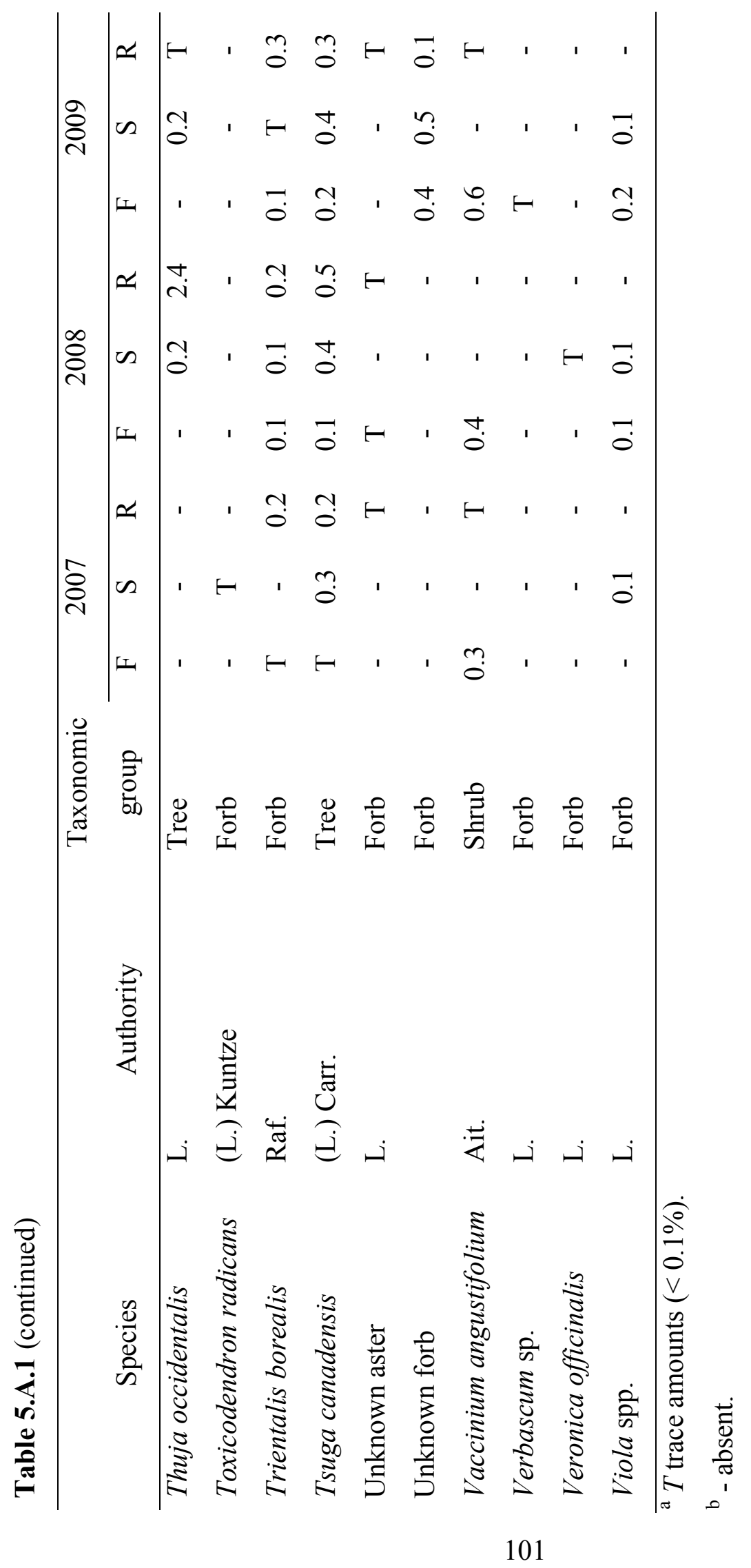




\section{Conclusions}

Browsing ungulates, such as moose and white-tailed deer, function as components within forest ecosystems. Their ecology touches on many concepts related to pattern and process in both temperate and boreal forests. The goal of this dissertation was to examine links between forest and ungulate ecology by studying their interaction via spatial and temporal patterns of resource availability, with a focus on nitrogen. Nitrogen tends to be a limiting nutrient to plant growth in these forest types, and it is consumed, concentrated, cycled, and transported by ungulates. When ungulates migrate consistently between habitats used for feeding and those used for other purposes, such as cover, there is likely to be net transport of nitrogen (Chapter 3). However, understory plants respond to resource availability on an individual basis, so that increasing the nitrogen budget of a forest stand is unnecessary for ungulate nitrogen inputs to have an ecologically meaningful effect on vegetation (Chapter 2). Nitrogen availability in plant tissues often corresponds with nutritional value and palatability. Foraging in patches of plants that are more nutritious and digestible is one behavior of ungulates that allows them to maintain a positive energy balance (Chapter 4). Selection of patches has implications for forest structure and composition, and plant life-history strategies.

At this point in the story, the stage is set for feedback loops to develop that are driven by ungulate foraging patch selection, which is driven by a variety of factors including cover (Verme 1973), food, landscape position, and winter weather (Morrison et al. 2003; Witt et al. 2012). Currently, winter deer use of remnant hemlock stands is positively correlated with deciduous sapling density in the understory (Jensen et al. 2011). Greater winter deer use would suggest more deer-excreted nitrogen inputs, resulting in a greater occurrence of urine-derived biogeochemical hotspots. As sugar maple is a luxury consumer of nitrogen, and luxury consumers are more preferred forage by deer (Tripler et al. 2002), more deer may aggregate in these stands. The juxtaposition of food and cover would make these winter deer populations less sensitive to fluctuations 
in deer population size, and may lead to greater aggregations of deer than those driven by hemlock cover alone. Deer browsing is another factor that could hasten a transition of hemlock stands to hardwood forests due to greater browse tolerance by deciduous species. However, if deer density of a preferred stand was suddenly reduced or eliminated, then increased cycling of nitrogen by sugar maple would be expected to inhibit hemlock regeneration. The current system may have already reached an alternate stable state even though the hemlock overstory will take centuries to senesce and transition to hardwoods. The results of this dissertation and the work of others (Witt and Webster 2010; Jensen et al. 2011) provide suggestive data that warrants further study.

Another future research question is how predation affects the relationship between ungulates and forest ecology. Predation risk varies across the landscape according to the distribution of relatively safe and risky foraging patches (Brown 1999). Areas of persistent wolf activity have been linked to greater plant diversity at local scales (Callan et al. 2013), possibly due to predator avoidance and/or reduced forage activity while present in those areas (e.g. Winnie and Creel 2007). Predation risk may be affecting spatial patterns of deer habitat use, or influencing forage intake rates (e.g. Altendof et al. 2001), in ways that affects their ecosystem functions.

A large body of literature on the negative effects of ungulate overabundance has been produced, especially focused on white-tailed deer (e.g. McShea et al. 1997; Russell et al. 2001; Côté et al. 2004). The studies contained in this dissertation will diversify the deer literature by describing the broader ecological function of deer in forest ecosystems. This function goes beyond deer eating plants to suggest that altering deer populations or habitat selection patterns may affect elemental cycling in forests.

The main management recommendation from this dissertation is that having suitable amounts of habitat available during each season is important for the sustainability of ungulate populations. The moose of Isle Royale have altered the landscape since their arrival 100 years ago, and the outcome of that interaction differs across the island. Planting or fencing off saplings is not a management option due to the National Park Services' policy of natural regulation. In the Upper Great Lakes region it may be possible to increase winter cover for deer by planting hemlock saplings in appropriate locations or building deer fences. The Forest Service has built fences in select 103 
location to prevent deer browsing, which we used in this study. The drawback of planting saplings is that they would take upwards of 100 years go reach a height where they would provide cover for deer. As explained in Chapter 5, the outlook for hemlock populations is unknown due to a number of factors including climate change, land-use change, deer, and the hemlock woolly adelgid. 


\section{Literature Cited}

Abbas, F., J. Merlet, N. Morellet, H. Verheyden, A. J. M. Hewison, B. Cargnelutti, J. M. Angibault, D. Picot, J. L. Rames, B. Lourtet, S. Aulagnier, and T. Daufresne. 2012. Roe deer may markedly alter forest nitrogen and phosphorus budgets across Europe. Oikos 121:1271-1278.

Abrams, M. D. 1998. The red maple paradox. Bioscience 48:355-364.

Afzal, M., and W. A. Adams. 1992. Heterogeneity of soil mineral nitrogen in pasture grazed by cattle. Soil Science Society of America Journal 56:1160-1166.

Altendof, K. B., J. W. Laundré, C. A. López González, and J. S. Brown. 2001. Assessing effects of predation risk on foraging behavior of mule deer. Journal of Mammalogy 82:430-439.

Alverson, W. S., D. M. Waller, and S. L. Solheim. 1988. Forests too deer: edge effects in northern Wisconsin. Conservation Biology 2:348-358.

Anderson, R. C., and O. L. Loucks. 1979. White-tail deer (Odocoileus virginianus) influence on structure and composition of Tsuga canadensis forests. Journal of Applied Ecology 16:855-861.

Augustine, D. J., and S. J. McNaughton. 1998. Ungulate effects on the functional species composition of plant communities: herbivore selectivity and plant tolerance. Journal of Wildlife Management 62:1165-1183.

Augustine, D. J., and D. A. Frank. 2001. Effects of migratory grazers on spatial heterogeneity of soil nitrogen properties in a grassland ecosystem. Ecology 82:3149-3162.

Augustine, D. J., S. J. McNaughton, and D. A. Frank. 2003. Feedbacks between soil nutrients and large herbivores in a managed savanna ecosystem. Ecological Applications 13:1325-1337.

Avery, T. E., and H. E. Burkhart. 2002. Forest Measurements, $5^{\text {th }}$ edition. McGraw-Hill, New York, NY, USA.

Bardgett, R. D., and D. A. Wardle. 2003. Herbivore-mediated linkages between aboveground and belowground communities. Ecology 84:2258-2268. 
Becker, C., R. Aschbacher, J. Johnson, and D. DeKoster. 1996. An evaluation of mechanical site preparation treatments to promote establishment of eastern hemlock (Tsuga canadensis) and northern white cedar (Thuja occidentalis). Pages 157-160 in G. Mroz and J. Martin. Hemlock Ecology and Management: Proceedings of a Regional Conference on Ecology and Management of Eastern Hemlock. Department of Forestry, University of Wisconsin-Madison, Madison, WI, USA.

Belovsky, G. E. 1981. Food plant selection by a generalist herbivore: the moose. Ecology 62:1020-1030.

Bergerud, A. T., and F. Manuel. 1968. Moose damage to balsam fir-white birch forests in central Newfoundland. Journal of Wildlife Management 32:729-746.

Bressette, J. W., H. Beck, and V. B. Beauchamp. 2012. Beyond the browse line: complex cascade effects mediated by white-tailed deer. Oikos 121:1749-1760.

Brown, J. S., J. W. Laundré, and M. Gurung. 1999. The ecology of fear: optimal foraging, game theory, and trophic interactions. Journal of Mammalogy 80:385399.

Bryant, J. P., F. S. Chapin, III, and D. R. Klein. 1983. Carbon/nutrient balance of boreal plants in relation to vertebrate herbivory. Oikos 40:357-368.

Bump, J. K., K. B. Tischler, A. J. Schrank, R. O. Peterson, and J. A. Vucetich. 2009a. Large herbivores and aquatic-terrestrial links in southern boreal forests. Journal of Animal Ecology 78:338-345.

Bump, J. K., C. R. Webster, J. A. Vucetich, R. O. Peterson, J. M. Shields, and M. D. Powers. 2009b. Ungulate carcasses perforate ecological filters and create biogeochemical hotspots in forest herbaceous layers allowing trees a competitive advantage. Ecosystems 12:996-1007.

Burney, O. T., and D. F. Jacobs. 2011. Ungulate herbivory of regenerating conifers in relation to foliar nutrition and terpenoid production. Forest Ecology and Management 262:1834-1845.

Burnham, K. P., and D. R. Anderson. 2002. Model selection and multimodel inference: a practical information-theoretic approach. Springer-Verlag, New York, New York, USA. 
Burnham, K. P., and D. R. Anderson. 2004. Multimodel inference: understanding AIC and BIC in model selection. Sociological Methods and Research 33:261-304.

Butler, L. G., and K. Kielland. 2008. Acceleration of vegetation turnover and element cycling by mammalian herbivory in riparian ecosystems. Journal of Ecology 96:136-144.

Calcote, R. 2003. Mid-Holocene climate and the hemlock decline: the range limit of Tsuga canadensis in the western Great Lakes region, USA. The Holocene 13:215224.

Callan, R., N. P. Nibbelink, T. P. Rooney, J. E. Wiedenhoeft, and A. P. Wydeven. 2013. Recolonizing wolves trigger a trophic cascade in Wisconsin (USA). Journal of Ecology 101:837-845.

Campbell, J. L., and S. T. Gower. Detritus production and soil N transformations in oldgrowth eastern hemlock and sugar maple stands. Ecosystems 3:185-192.

Clarke, K. R. 1993. Non-parametric multivariate analyses of changes in community structure. Australian Journal of Ecology 18:117-143.

Clinger, W., and J. W. Van Ness. 1976. On unequally spaced time points in time series. Annals of Statistics 4:736-745.

Coley, P. D., J. P. Bryant, and F. S. Chapin, III. 1985. Resource availability and plant antiherbivore defense. Science 230:895-899.

Côté, S. D., T. P. Rooney, J.-P. Tremblay, C. Dussault, and D. M. Waller. 2004. Ecological impacts of deer overabundance. Annual Review of Ecology, Evolution, and Systematics 35:113-147.

Coughenour, M. B. 1985. Graminoid responses to grazing by large herbivores: adaptations, exaptations, and interacting processes. Annals of the Missouri Botanical Garden 72:852-863.

Danell, K., P. Niemelä, T. Varvikko, and T. Vuorisalo. 1991. Moose browsing on Scots pine along a gradient of plant productivity. Ecology 72:1624-1633.

Davis, M. B., R. R. Calcote, S. Sugita, and H. Takahara. 1998. Patchy invasion and the origin of a hemlock-hardwoods forest mosaic. Ecology 79:2641-2659. 
Dayton, P. K. 1972. Toward an understanding of community resilience and the potential effects of enrichment to the benthos at McMurdo Sound, Antarctica. In B. C. Parker. Proceedings of the Colloquium on Conservation Problems in Antarctica. Allen Press, Lawrence, KS, USA.

De Mazancourt, C., M. Loreau, and L. Abbadie. 1998. Grazing optimization and nutrient cycling: when do herbivores enhance plant production?. Ecology 79:2242-2252.

DelGiudice, G. D., L. D. Mech, U. S. Seal, and P. D. Karns. 1987. Winter fasting and refeeding effects on urine characteristics in white-tailed deer. Journal of Wildlife Management 51:860-864.

DelGiudice, G. D., and U. S. Seal. 1988. Classifying winter undernutrition in deer via serum and urinary nitrogen. Wildlife Society Bulletin 16:27-32.

DelGiudice, G. D., K. R. McCaffery, D. E. Beyer Jr., and M. E. Nelson. 2009. Prey of wolves in the Great Lakes region. Pages 155-173 in A. P. Wydeven, T. R. Van Deelen, and E. J. Heske. Recovery of Gray Wolves in the Great Lakes Region of the United States. Springer, New York, NY, USA.

DeYoung, R. W., and K. V. Miller. 2011. White-tailed deer behavior. Pages 311-351 in D. G. Hewitt. Biology and Management of White-Tailed Deer. CRC Press, Boca Raton, FL, USA.

Doepker, R. V., D. E. Beyer Jr., and M. Donovan. 1996. Deer population trends in Michigan's Upper Peninsula. Pages 99-108 in G. Mroz and J. Martin. Hemlock Ecology and Management: Proceedings of a Regional Conference on Ecology and Management of Eastern Hemlock. Department of Forestry, University of Wisconsin-Madison, Madison, WI, USA.

Donoso, P. J., and R. D. Nyland. 2006. Interference to hardwood regeneration in northeastern North America: The effects of raspberries (Rubus spp.) following clearcutting and shelterwood methods. Northern Journal of Applied Forestry 23:288-296.

Duchesne, L. C., C. Mueller-Rowat, L. M. Clark, and F. Pinto. 1999. Effect of organic matter removal, ashes and shading on eastern hemlock, Tsuga canadensis, seedling emergence from soil monoliths under greenhouse conditions. Canadian Field-Naturalist 113:264-268. 
Dufrêne, M., and P. Legendre. 1997. Species assemblages and indicator species: the need for a flexible asymmetrical approach. Ecological Monographs 67:345-366.

Eckstein, R. G. 1980. Eastern hemlock (Tsuga canadensis) in north central Wisconsin. Wisconsin Department of Natural Resources Report 104.

Edenius, L., K. Danell, and R. Bergström. 1993. Impact of herbivory and competition on compensatory growth in woody plants: winter browsing by moose on Scots pine. Oikos 66:286-292.

Ellison, A. M., M. S. Bank, B. D. Clinton, E. A. Colburn, K. Elliott, C. R. Ford, D. R. Foster, B. D. Kloeppel, J. D. Knoepp, G. M. Lovett, J. Mohan, D. A. Orwig, N. L. Rodenhouse, W. V. Sobczak, K. A. Stinson, J. K. Stone, C. M. Swan, J.

Thompson, B. Von Holle and J. R. Webster. 2005. Loss of foundation species: consequences for the structure and dynamics of forested ecosystems. Frontiers in Ecology and the Environment 3:479-486.

ESRI. 2012. ArcGIS Desktop: Release 10.1. Environmental Systems Research Institute, Redlands, CA, USA.

Euler, D., and L. Thurston. 1980. Characteristics of hemlock stands related to deer use in east-central Ontario. Journal of Applied Ecology 17:1-6.

Farley, R. A., and A. H. Fitter. 1999. The responses of seven co-occurring woodland herbaceous perennials to localized nutrient-rich patches. Journal of Ecology 87:849-859.

Feeley, K. J. and Terborgh, J. W. 2005. The effects of herbivore density on soil nutrients and tree growth in tropical forest fragments. Ecology 86:116-124.

Ferrari, J. B. 1999. Fine-scale patterns of leaf litterfall and nitrogen cycling in an oldgrowth forest. Canadian Journal of Forest Research 29:291-302.

Foster, D. R. 1988. Disturbance history, community organization and vegetation dynamics of the old-growth Pisgah Forest, southwestern New Hampshire, USA. Journal of Ecology 76:105-134.

Foster, D. R., D. H. Knight, J. F. Franklin. 1998. Landscape patterns and legacies resulting from large, infrequent forest disturbances. Ecosystems 1:497-510. 
Foster, D. R., W. W. Oswald, E. K. Faison, E. D. Doughty, and B. C. S. Hansen. 2006. A climatic driver for abrupt mid-Holocene vegetation dynamics and the hemlock decline in New England. Ecology 87:2959-2966.

Frank, D. A., R. S. Inouye, N. Huntly, G. W. Minshall, and J. E. Anderson. 1994. The biogeochemistry of a north-temperate grassland with native ungulates: nitrogen dynamics in Yellowstone National Park. Biogeochemistry 26:163-188.

Frelich, L. E. 1995. Old forest in the Lake States today and before European settlement. Natural Areas Journal 15:157-167.

Frelich, L. E. 2002. Forest Dynamics and Disturbance Regimes. Cambridge University Press, Cambridge, UK.

Frelich, L. E., and C. G. Lorimer. 1985. Current and predicted long-term effects of deer browsing in hemlock forests in Michigan, USA. Biological Conservation 34:99120.

Frelich, L. E., and C. G. Lorimer. 1991. Natural disturbance regimes in hemlockhardwood forests of the upper Great Lakes region. Ecological Monographs $61: 145-164$.

Frelich, L. E., R. R. Calcote, M. B. Davis, and J. Pastor. 1993. Patch formation and maintenance in an old-growth hemlock-hardwood forest. Ecology 74:513-527.

Frelich, L. E., and L. J. Graumlich. 1994. Age-class distribution and spatial patterns in an old-growth hemlock-hardwood forest. Canadian Journal of Forest Research 24:1939-1947.

George, L. O., and F. A. Bazzaz. 1999. The fern understory as an ecological filter: growth and survival of canopy-tree seedlings. Ecology 80:846-856.

George, L. O., and F. A. Bazzaz. 2003. The herbaceous layer as a filter determining spatial pattern in forest tree regeneration. Pages 265-282 in F. S. Gilliam and M. R. Roberts. The Herbaceous Layer of Forests in Eastern North America. Oxford University Press, Oxford, UK.

Giblin, A. E, J. A. Laundré, K. J. Nadelhoffer, and G. R. Shaver. 1994. Measuring nutrient availability in arctic soils using ion exchange resins: a field test. Soil Science Society of America Journal 58:1154-1162. 
Gilliam, F. S. 2006. Response of the herbaceous layer of forest ecosystems to excess nitrogen deposition. Journal of Ecology 94:1176-1191.

Gilliam, F. S. 2007. The ecological significance of the herbaceous layer in temperate forest ecosystems. BioScience 57:845-858.

Gilliam, F. S. and Roberts, M. R. 2003. Introduction: conceptual framework for studies of the herbaceous layer. Pages 3-14 in F. S. Gilliam and M. R. Roberts. The Herbaceous Layer of Forests in Eastern North America. Oxford University Press, Oxford, UK.

Godman, R. M., and K. Lancaster. 1990. Eastern hemlock. In R. M. Burns and B. H. Honkala. Silvics of North America: I. Conifers. Forest Service, United States Department of Agriculture, Washington, DC, USA.

Godman, R. M., H. W. Yawney, and C. H. Tubbs. 1990. Sugar maple. In R. M. Burns and B. H. Honkala. Silvics of North America: II. Hardwoods. Forest Service, United States Department of Agriculture, Washington, DC, USA.

Goff, F. G. 1967. VI. Upland Vegetation. Pages 60-90 in C. J. Milfred, G. W. Olsen, and F. D. Hole. Soil Resources and Forest Ecology of Menominee County, Wisconsin, Wisconsin Geological and Natural History Survey Bulletin 85, Soil Series No. 60. University of Wisconsin-Madison, Madison, Wisconsin, USA.

Goovaerts, P. 1998. Geostatistical tools for characterizing the spatial variability of microbiological and physico-chemical soil properties. Biology and Fertility of Soils 27:315-334.

Gotelli, N. J. and Ellison, A. M. 2004. A Primer of Ecological Statistics. Sinauer Associates, Inc., Sunderland, Massachusetts, USA.

Graham, S. A. 1941. The question of hemlock establishment. Journal of Forestry 39:567569.

Harpole, W. S., and D. Tilman. 2007. Grassland species loss resulting from reduced niche dimension. Nature 446:791-793.

Hayhoe, K., J. VanDorn, T. Croley, N. Schlegal, and D. Wuebbles. 2010. Regional climate change projections for Chicago and the US Great Lakes. Journal of Great Lakes Research 36:7-21. 
He, H. S., and D. J. Mladenoff. 1999. Spatially explicit and stochastic simulation of forest-landscape fire disturbance and succession. Ecology 80:81-99.

Heckel, C. D., N. A. Bourg, W. J. McShea, and S. Kalisz. 2010. Nonconsumptive effects of a generalist ungulate herbivore drive decline of unpalatable forest herbs. Ecology 91:319-326.

Hermy, M. 1988. Accuracy of visual cover assessments in predicting standing crop and environmental correlation in deciduous forests. Vegetatio 75:57-64.

Hibbs, D. E. 1982. Gap dynamics in a hemlock-hardwood forest. Canadian Journal of Forest Research 12:522-527.

Hobbs, N. T. 1996. Modification of ecosystems by ungulates. Journal of Wildlife Management 60:695-713.

Hobbs, N. T. 2006. Large herbivores as sources of disturbance in ecosystems. Pages 261288 in K. Danell, R. Bergström, P. Duncan, and J. Pastor. Large Herbivore Ecology, Ecosystem Dynamics and Conservation. Cambridge University Press, Cambridge, UK.

Holdo, R. M., R. D. Holt, M. B. Coughenour, and M. E. Ritchie. 2007. Plant productivity and soil nitrogen as a function of grazing, migration and fire in an African savanna. Journal of Ecology 95:115-128.

Holmes, S. A., and C. R. Webster. 2011. Herbivore-induced expansion of generalist species as a driver of homogenization in post-disturbance plant communities. Plant Ecology 212:753-768.

Hough, A. F., and R. D. Forbes. 1943. The ecology and silvics of forests in the high plateaus of Pennsylvania. Ecological Monographs 13:299-320.

Houle, G. 1999. Mast seeding in Abies balsamea, Acer saccharum, and Betula alleghaniensis in an old-growth, cold temperate forest in north-eastern North America. Journal of Ecology 87:413-422.

Howe, R. W., and M. Mossman. 1996. The significance of hemlock for breeding birds in the western Great Lakes region. Pages 125-140 in G. Mroz and J. Martin. Hemlock Ecology and Management: Proceedings of a Regional Conference on Ecology and Management of Eastern Hemlock. Department of Forestry, University of Wisconsin-Madison, Madison, WI, USA. 
Huber, N. K. 1973. Glacial and postglacial geologic history of Isle Royale National Park, Michigan. Geologic Survey Professional Paper 754-A. United States Department of the Interior, Washington, DC, USA.

Hurley, P. M., C. R. Webster, D. J. Flaspohler, and G. R. Parker. 2012. Untangling the landscape of deer overabundance: reserve size versus landscape context in the agricultural Midwest. Biological Conservation 146:62-71.

Iverson, L., A. Prasad, and S. Matthews. 2008. Modeling potential climate change impacts on the trees of the northeastern United States. Mitigation and Adaptation Strategies for Global Change 13:487-516.

Jenkins, J. C., J. D. Aber, and C. D. Canham. 1999. Hemlock woolly adelgid impacts on community structure and $\mathrm{N}$ cycling rates in eastern hemlock forests. Canadian Journal of Forest Research 29:630-645.

Jenkins, M. A., C. R. Webster, G. R. Parker, and M. A. Spetich. 2004. Coarse woody debris in managed Central Hardwood Forests of Indiana, USA. Forest Science 50:781-792.

Jensen, N. R., C. R. Webster, J. C. Witt, and J. B. Grant. 2011. Ungulate winter habitat selection as a driver of herbaceous-layer heterogeneity in northern temperate forests. Ecosphere 2:67.

Johnston, W. F. 1990. Northern white-cedar. In R. M. Burns and B. H. Honkala. Silvics of North America: I. Conifers. Forest Service, United States Department of Agriculture, Washington, DC, USA.

Kartesz, J. T. 1999. A synonymized checklist and atlas with biological attributes for the vascular flora of the United States, Canada, and Greenland. In J. T. Kartesz and C. A. Meacham. Synthesis of the North American Flora, version 1, first edition. North Carolina Botanical Garden, Chapel Hill, North Carolina, USA.

Keitt, T. H., R. Bivand, E. Pebesma, and B. Rowlingson. 2012. RGDAL: bindings for the geospatial data abstraction library. R package version 0.7-11. Available online: http://CRAN.R-project.org/package=rgdal.

Krapfl, K. J., E. J. Holzmueller, and M. A. Jenkins. 2011. Early impacts of hemlock woolly adelgid in Tsuga canadensis forest communities of the southern Appalachian Mountains. Journal of the Torrey Botanical Society 138:93-106. 113 
Leopold, A., L. K. Sowls, and D. L. Spencer. 1947. A survey of over-populated deer ranges in the United States. Journal of Wildlife Management 11:162-177.

Levin, S. A. 1992. The problem of pattern and scale in ecology. Ecology 73:1943-1967.

Loreau, M. 2010. From Populations to Ecosystems: Theoretical Foundations for a New Ecological Synthesis. Monographs in Population Biology 46. Princeton University Press, Princeton, New Jersey, USA.

Lorimer, C. G., S. E. Dahir, and M. T. Singer. 1999. Frequency of partial and missing rings in Acer saccharum in relation to canopy position and growth rate. Plant Ecology 143:189-202.

Lovett, G. M., K. C. Weathers, M. A. Arthur, and J. C. Schultz. 2004. Nitrogen cycling in a northern hardwood forest: do species matter?. Biogeochemistry 67:289-308.

Maissurow, D. K. 1941. The role of fire in the perpetuation of virgin forests of northern Wisconsin. Journal of Forestry 39:201-207.

Marsh, K. J., I. R. Wallis, R. L. Andrew, and W. J. Foley. 2006. The detoxification limitation hypothesis: where did it come from and where is it going? Journal of Chemical Ecology 32:1247-1266.

Marx, L., and M. B. Walters. 2008. Survival of tree seedlings on different species of decaying wood maintains tree distribution in Michigan hemlock-hardwood forests. Journal of Ecology 96:505-513.

Maschinski, J., and T. G. Whitham. 1989. The continuum of plant responses to herbivory: the influence of plant association, nutrient availability, and timing. American Naturalist 134:1-19.

McCune, B., and J. B. Grace. 2002. Analysis of Ecological Communities. MjM Software Design, Gleneden Beach, Oregon, USA.

McCune, B., and M. J. Mefford. 2006. PC-ORD Multivariate Analysis of Ecological Data v. 5. MjM Software Design, Gleneden Beach, Oregon, USA.

McLaren, B. E. 1996. Plant-specific response to herbivory: simulated browsing of suppressed balsam fir on Isle Royale. Ecology 77:228-235.

McNaughton, S. J. 1985. Ecology of a grazing ecosystem: the Serengeti. Ecological Monographs 55:259-294. 
McShea, W. J., H. B. Underwood, and J. H. Rappole. 1997. Deer management and the concept of overabundance. Pages 1-7 in W. J. McShea, H. B. Underwood, and J. H. Rappole. The Science of Overabundance: Deer Ecology and Population Management. Smithsonian Institution Press, Washington, DC, USA.

Miekle, P. W., and K. J. Berry. 2001. Permutation methods: a distance function approach. Springer-Verlag, Berlin, Germany.

Miles, M. L., and E. C. Smith. 1960. A study of the origin of hemlock forests in southwestern Nova Scotia. The Forestry Chronicle 36:375-390.

Minitab, Inc. 2010. Minitab Release 16 for Windows. Minitab, Inc., State College, PA, USA.

Mladenoff, D. J. 1987. Dynamics of nitrogen mineralization and nitrification in hemlock and hardwood treefall gaps. Ecology 68:1171-1180.

Mladenoff, D. J., and F. Stearns. 1993. Eastern hemlock regeneration and deer browsing in the northern Great Lakes region: a re-examination and model simulation. Conservation Biology 7:889-900.

Moen, R., J. Pastor, and Y. Cohen. 1997. A spatially explicit model of moose foraging and energetic. Ecology 78:505-521.

Molvar, E. M., R. T. Bowyer, V. Van Ballenberghe, and V. Van Brauenberone. 1993. Moose herbivory, browse quality, and nutrient cycling in an Alaskan treeline community. Oecologia 94:472-479.

Morrison, S. F., G. J. Forbes, S. J. Young, and S. Lusk. 2003. Within-yard habitat use by white-tailed deer at varying winter severity. Forest Ecology and Management 172:173-182.

Murray, B. D., C. R. Webster, and J. K. Bump. 2013. Broadening the ecological context of ungulate-ecosystem interactions: the importance of space, seasonality, and nitrogen. Ecology 94:1317-1326.

Mysterud, A., F. J. Pérez-Barbería, and I. J. Gordon. 2001. The effect of season, sex and feeding style on home range area versus body mass scaling in temperate ruminants. Oecologia 127:30-39. 
National Climatic Data Center. 2012. Climate monitoring reports and products, PDSI.

National Oceanic and Atmospheric Administration, United States Department of Commerce.

National Operational Hydrologic Remote Sensing Center. 2004. Snow Data Assimilation System (SNODAS) Data Products at NSIDC, Nov 16-May 15 in 2005-2013. Boulder, Colorado USA: National Snow and Ice Data Center. Digital media.

Olofsson, J., S. Stark, and L. Oksanen. 2004. Reindeer influence on ecosystem processes in the tundra. Oikos 105:386-396.

Pastor, J., and R. J. Naiman. 1992. Selective foraging and ecosystem processes in boreal forests. American Naturalist 139:690-705.

Pastor, J., B. Dewey, R. J. Naiman, P F. McInnes, and Y. Cohen. 1993. Moose browsing and soil fertility in the boreal forests of Isle Royale National Park. Ecology 74:467-480.

Pastor, J., Y. Cohen, and N. T. Hobbs. 2006. The roles of large herbivores in ecosystem nutrient cycling. Pages 289-325 in K. Danell, R. Bergström, P. Duncan, and J. Pastor. Large Herbivore Ecology, Ecosystem Dynamics and Conservation. Cambridge University Press, Cambridge, UK.

Pebesma, E. J. 2004. Multivariable geostatistics in S: the GSTAT package. Computers and Geosciences 30:683-691.

Peek, J. M., D. L. Urich, and R. J. Mackie. 1976. Moose habitat selection and relationships to forest management in northeastern Minnesota. Wildlife Monographs 48:3-65.

Peek, M. S., and I. N. Forseth. 2003. Enhancement of photosynthesis and growth of an aridland perennial in response to soil nitrogen pulses generated by mule deer. Environmental and Experimental Botany 49:169-180.

Perrin, P. M., F. J. G. Mitchell, and D. L. Kelly. 2011. Long-term deer exclusion in yewwood and oakwood habitats in southwest Ireland: changes in ground flora and species diversity. Forest Ecology and Management 262:2328-2337.

Persson, I.-L., K. Danell, and R. Bergström. 2000. Disturbance by large herbivores in boreal forests with special reference to moose. Annales Zoologici Fennici 37:251263. 
Pubanz, D. M. 1996. Regeneration and historical growth patterns in large-diameter hemlock on Menominee tribal lands. Pages 175-177 in G. Mroz and J. Martin. Hemlock Ecology and Management: Proceedings of a Regional Conference on Ecology and Management of Eastern Hemlock. Department of Forestry, University of Wisconsin-Madison, Madison, WI, USA.

Putman, R. J. 1996. Ungulates in temperate forest ecosystems: perspectives and recommendations for future research. Forest Ecology and Management 88:205214.

R Development Core Team. 2012. R: A language and environment for statistical computing. Ver. 2.15.0. R Foundation for Statistical Computing. Available online: http://www.R-project.org.

Raudenbush, S. W., M.-L. Yang, and M. Yosef. 2000. Maximum likelihood for generalized linear models with nested random effects via high-order, multivariate Laplace approximation. Journal of Computational and Graphical Statistics 9:141157.

Richardson, A. D. 2004. Foliar chemistry of balsam fir and red spruce in relation to elevation and the canopy light gradient in the mountains of the northeastern United States. Plant and Soil 260:291-299.

Ripple, W. J., T. P. Rooney, and R. L. Beschta. 2010. Large predators, deer, and trophic cascades in boreal and temperate ecosystems. Pages 141-162 in J. Terborgh and J.A. Estes. Trophic Cascades: Predators, Prey, and the Changing Dynamics of Nature. Island Press, Washington, DC, USA.

Ritchie, M. E. 2010. Scale, Heterogeneity, and the Structure and Diversity of Ecological Communities. Monographs in Population Biology 45. Princeton University Press, Princeton, New Jersey, USA.

Ritchie, M. E., D. Tilman, and J. M. H. Knops. 1998. Herbivore effects on plant and nitrogen dynamics in oak savanna. Ecology 79:165-177.

Roberts, M. R., and F. S. Gilliam. 2003. Response of the herbaceous layer to disturbance in eastern forests. Pages 302-322 in F. S. Gilliam and M. R. Roberts. The Herbaceous Layer of Forests in Eastern North America. University of Oxford Press, Oxford, UK. 
Rongstad, O. J., and J. R. Tester. 1969. Movements and habitat use of white-tailed deer in Minnesota. Journal of Wildlife Management 33:366-379.

Rooney, T. P. 2009. High white-tailed deer densities benefit graminoids and contribute to biotic homogenization of forest ground-layer vegetation. Plant Ecology 202:103111.

Rooney, T. P., and W. J. Dress. 1997. Species loss over sixty-six years in the groundlayer vegetation of Heart's Content, an old-growth forest in Pennsylvania, USA. Natural Areas Journal 17:297-305.

Rooney, T. P., and D. M. Waller. 1998. Local and regional variation in hemlock seedling establishment in forests of the upper Great Lakes region, USA. Forest Ecology and Management 111:211-224.

Rooney, T. P., R. J. McCormick, S. L. Solheim, and D. M. Waller. 2000. Regional variation in recruitment of hemlock seedlings and saplings in the upper Great Lakes, USA. Ecological Applications 10:1119-1132.

Rooney, T. P., S. L. Solheim, and D. M. Waller. 2002. Factors affecting the regeneration of northern white cedar in lowland forests of the Upper Great Lakes region, USA. Forest Ecology and Management 163:119-130.

Rooney, T. P., and D. M. Waller. 2003. Direct and indirect effects of white-tailed deer in forest ecosystems. Forest Ecology and Management 181:165-176.

Rooney, T. P., S. M. Wiegmann, D. A. Rogers, and D. M. Waller. 2004. Biotic impoverishment and homogenization in unfragmented forest understory communities. Conservation Biology 18:787-798.

Roseberry, J. L., and A. Woolf. 1991. A comparative evaluation of techniques for analyzing white-tailed deer harvest data. Wildlife Monographs 117:3-59.

Royo, A. A., R. Collins, M. B. Adams, C. Kirschbaum, and W. P. Carson. 2010. Pervasive interactions between ungulate browsers and disturbance regimes promote temperate forest herbaceous diversity. Ecology 91:93-105.

Runkle, J. R. 1982. Patterns of disturbance in some old-growth mesic forests of eastern North America. Ecology 63:1533-1546. 
Russell, F. L., D. B. Zippin, and N. L. Fowler. 2001. Effects of white-tailed deer (Odocoileus virginianus) on plants, plant populations and communities: a review. American Midland Naturalist 146:1-26.

Rutherford, A. C., and O. J. Schmitz. 2010. Regional-scale assessment of deer impacts on vegetation within western Connecticut, USA. Journal of Wildlife Management $74: 1257-1263$

Salk, T. T., L. E. Frelich, S. Sugita, R. Calcote, J. B. Ferrari, and R. A. Montgomery. 2011. Poor recruitment is changing the structure and species composition of an old-growth hemlock-hardwood forest. Forest Ecology and Management 261:1998-2006.

Sauvé, D. G., and S. D. Côté. 2006. Is winter diet quality related to body condition of white-tailed deer (Odocoileus virginianus)? An experiment using urine profiles. Canadian Journal of Zoology 84:1003-1010.

Scheller, R. M., and D. J. Mladenoff. 2002. Understory species patterns and diversity in old-growth and managed northern hardwood forests. Ecological Applications 12:1329-1343.

Schmitz, O. J. 2010. Resolving Ecosystem Complexity. Monographs in Population Biology 47. Princeton University Press, Princeton, New Jersey, USA.

Schmitz, O. J., and A. R. E. Sinclair. 1997. Rethinking the role of deer in forest ecosystem dynamics. Pages 201-223 in W. J. McShea, J. H. Rappole, and H. B. Underwood. The Science of Overabundance: Deer Ecology and Population Management. Smithsonian Books, Washington, District of Columbia, USA.

Schoener, T. W. 1971. Theory of feeding strategies. Annual Review of Ecology and Systematics 2:369-404.

Scogings, P. F., J. Hjältén, and C. Skarpe. 2011. Secondary metabolites and nutrients of woody plants in relation to browsing intensity in African savannas. Oecologia 167:1063-1073.

Seagle, S. W. 2003. Can ungulates foraging in a multiple-use landscape alter forest nitrogen budgets?. Oikos 103:230-234. 
Simpson, T. B., P. E. Stuart, and B. V. Barnes. 1990. Landscape ecosystems and cover types of the reserve area and adjacent lands of the Huron Mountain Club. The Huron Mountain Wildlife Foundation, Big Bay, MI, USA.

Singer, F. J., and K. A. Schoenecker. 2003. Do ungulates accelerate or decelerate nitrogen cycling? Forest Ecology and Management 181:189-204.

Skogley, E. O., and A. Dobermann. 1996. Synthetic ion-exchange resins: soil and environmental variables. Journal of Environmental Quality 25:13-24.

Smith, W. P. 1991. Odocoileus virginianus. Mammalian Species 388:1-13.

Snyder, C. D., J. A. Young, D. P. Lemarie, and D. R. Smith. 2002. Influence of eastern hemlock (Tsuga canadensis) forests on aquatic invertebrate assemblages in headwater streams. Canadian Journal of Fisheries and Aquatic Sciences 59:262275.

Snyder, J. D., and R. A. Janke. 1976. Impact of moose browsing on boreal-type forests of Isle Royale National Park. American Midland Naturalist 95:79-92.

Soil Survey Staff, Natural Resources Conservation Service, United States Department of Agriculture, Soil Survey Geographic (SSURGO) Database for Baraga County, Michigan; Gogebic County, Michigan; and Houghton County, Michigan. Available online: http://soildatamart.nrcs.usda.gov. Accessed 29 May 2012.

Speer, J.H. 2010. Fundamentals of Tree Ring Research. The University of Arizona Press, Tucson, AZ, USA.

Steinauer, E. M., and S. L. Collins. 1995. Effects of urine deposition on small-scale patch structure in prairie vegetation. Ecology 76:1195-1205.

Stewart, K. M., R. T. Bowyer, and P. J. Weisberg. 2011. Spatial use of landscapes. Pages 181-217 in D. G. Hewitt. Biology and Management of White-Tailed Deer. CRC Press, Boca Raton, FL, USA.

Stokes, M.A. and T.L. Smiley. 1996. An Introduction to Tree-Ring Dating. The University of Arizona Press, Tucson, AZ, USA.

Stromayer, K. A. K., and R. J. Warren. 1997. Are overabundant deer herds in the eastern United States creating alternate stable states in forest plant communities?. Wildlife Society Bulletin 25:227-234. 
Stueve, K. M., C. H. Perry, M. D. Nelson, S. P. Healey, A. D. Hill, G. G. Moisen, W. B. Cohen, D. D. Gormanson, and C. Huang. 2011. Ecological importance of intermediate windstorms rivals large, infrequent disturbances in the northern Great Lakes. Ecosphere 2:2.

Talhelm, A. F., K. S. Pregitzer, A. J. Burton, and D. R. Zak. 2012. Air pollution and the changing biogeochemistry of northern forests. Frontiers in Ecology and the Environment 10:181-185.

Talhelm, A. F., A. J. Burton, K. S. Pregitzer, M. A. Campione. 2013. Chronic nitrogen deposition reduces the abundance of dominant forest understory groundcover species. Forest Ecology and Management 293:39-48.

Thompson, C. B., J. B. Holter, H. H. Hayes, H. Silver, and W. E. Urban Jr. 1973. Nutrition of white-tailed deer I: energy requirements of fawns. Journal of Wildlife Management 37:301-311.

Tilghman, N. G. 1989. Impacts of white-tailed deer on forest regeneration in northwestern Pennsylvania. Journal of Wildlife Management 53:524-532.

Towne, E. G. 2000. Prairie vegetation and soil nutrient responses to ungulate carcasses. Oecologia 122:232-239.

Tripler, C. E., C. D. Canham, R. S. Inouye, and J. L. Schnurr. 2002. Soil nitrogen availability, plant luxury consumption, and herbivory by white-tailed deer. Oecologia 133:517-524.

Turner, M. G., W. H. Romme, and D. B. Tinker. 2003. Surprises and lessons from the 1988 Yellowstone fires. Frontiers in Ecology and the Environment 1:351-358.

Van Deelen, T. R., H. Campa, III, M. Hamady, and J. B. Haufler. 1998. Migration and seasonal range dynamics of deer using adjacent deeryards in northern Michigan. Journal of Wildlife Management 62:205-213.

Venables, W. N., and B. D. Ripley. 2002. Modern Applied Statistics with S. Fourth Edition. Springer, New York, NY, USA.

Verme, L. J. 1973. Movements of white-tailed deer in upper Michigan. Journal of Wildlife Management 37:545-552.

Vitousek, P. M., and R. W. Howarth. 1991. Nitrogen limitation on land and in the sea: how can it occur? Biogeochemistry 13:87-115. 
Vitousek, P. M., H. A. Mooney, J. Lubchenco, and J. M. Melillo. 1997. Human domination of earth's ecosystems. Science 277:494-499.

Vucetich, J. A., and R. O, Peterson. 2004. The influence of prey consumption and demographic stochasticity on population growth rate of Isle Royale wolves Canis lupus. Oikos 107:309-320.

Wallmo, O. C. 1981. Mule and Black-Tailed Deer of North America. University of Nebraska Press, Lincoln, Nebraska, USA.

Walters, R. S., and H. W. Yawney. 1990. Red maple. In R. M. Burns and B. H. Honkala. Silvics of North America: I. Conifers. Forest Service, United States Department of Agriculture, Washington, DC, USA.

Webster, C. R., M. A. Jenkins, and J. H. Rock. 2005. Long-term response of spring flora to chronic herbivory and deer exclusion in Great Smoky Mountains National Park, USA. Biological Conservation 125:297-307.

Weisberg, P. J., and H. Bugmann. 2003. Forest dynamics and ungulate herbivory: from leaf to landscape. Forest Ecology and Management 181:1-12.

Weisberg, P. J., M. B. Coughenour, and H. Bugmann. 2006. Modeling of large herbivorevegetation interactions in a landscape context. Pages 348-382 in K. Danell, R. Bergström, P. Duncan, and J. Pastor. Large Herbivore Ecology, Ecosystem Dynamics and Conservation. Cambridge University Press, Cambridge, UK.

Western Regional Climatic Center. 2012. USA Divisional Climate Data. Western Regional Climate Center, Desert Research Institute, Reno, NV, USA.

Whittaker, R. H. 1956. Vegetation of the Great Smoky Mountains. Ecological Monographs 26:1-80.

Wickham, H. 2009. GGPLOT2: Elegant Graphics for Data Analysis. Springer-Verlag, New York, New York, USA.

WinSCANOPY. 2005. WinSCANOPY 2005a for hemispherical image analysis. Regent Instruments Inc., Québec, Canada.

Winnie, J., Jr., and S. Creel 2007. Sex-specific behavioural responses of elk to spatial and temporal variation in the threat of wolf predation. Animal Behaviour 73:215-225. 
Witt, J. C., and C. R. Webster. 2010. Regeneration dynamics in remnant Tsuga canadensis stands in the northern Lake States: potential direct and indirect effects of herbivory. Forest Ecology and Management 260:519-525.

Witt, J. C., C. R. Webster, R. E. Froese, T. D. Drummer, and J. A. Vucetich. 2012. Scaledependent drivers of ungulate patch use along a temporal and spatial gradient of snow depth. Canadian Journal of Zoology 90:972-983.

Wydeven, A. P., and R. W. Hay. 1996. Mammals, amphibians and reptiles of hemlock forests in the Lake Superior region. Pages 115-124 in G. Mroz and J. Martin. Hemlock Ecology and Management: Proceedings of a Regional Conference on Ecology and Management of Eastern Hemlock. Department of Forestry, University of Wisconsin-Madison, Madison, WI, USA.

Yamasaki, M., R. M. DeGraff, and J. W. Lanier. 2000. Wildlife habitat associations in eastern hemlock: birds, smaller mammals, and forest carnivores. Pages 135-143 in K. A. McMannus, K. S. Shields, and D. R. Souto. Proceedings: Symposium on Sustainable Management of Hemlock Ecosystems in Eastern North America. Forest Service, United States Department of Agriculture, Newtown Square, PA, USA.

Zak, D. R., P. M. Groffman, K. S. Pregitzer, S. Christensen, and J. M. Tiedje. 1990. The vernal dam: plant-microbe competition for nitrogen in northern hardwood forests. Ecology 71:651-656.

Ziegler, S. S. 2000. A comparison of structural characteristics between old-growth and postfire second-growth hemlock-hardwood forests in Adirondack Park, New York, USA. Global Ecology and Biogeography 9:373-389.

Zuur, A. F., E. N. Ieno, N. J. Walker, A. A. Saveliev, and G. M. Smith. 2009. Mixed Effects Models and Extensions in Ecology with R. Springer, New York, NY, USA. 